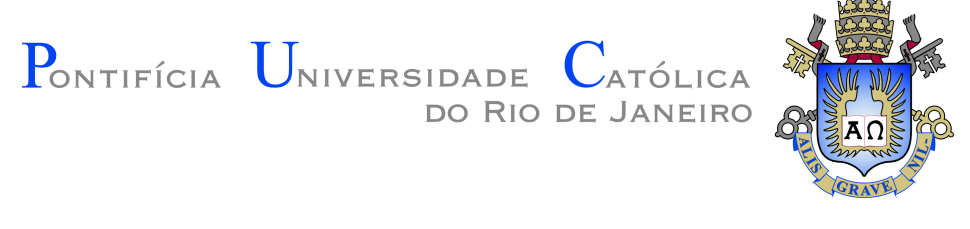

Gilberto Mendes Correia Junior

\title{
Os CANVAS aplicados ao Design de Serviço: novos conhecimentos para a formação de \\ designers
}

Dissertação de Mestrado

Dissertação apresentada como requisito parcial para obtenção do grau de Mestre pelo Programa de Pós-graduação em Programa de Pós-Graduação em Design, do Departamento de Artes e Design da PUC-Rio.

Orientador : Dra. Rita Maria de Souza Couto Coorientador: Dr. Luiz Antônio Fernandez Braga 


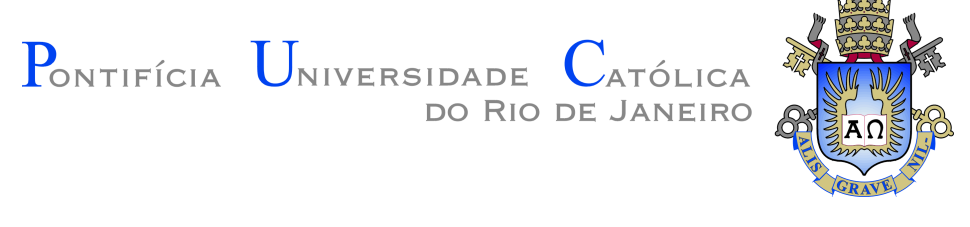

\title{
Gilberto Mendes Correia Junior
}

\section{Os CANVAS aplicados ao Design de Serviço: novos conhecimentos para a formação de designers}

Dissertação apresentada como requisito parcial para obtenção do grau de Mestre pelo Programa de Pós-graduação em Programa de Pós-Graduação em Design da PUC-Rio. Aprovada pela Comissão Examinadora abaixo:

\author{
Dra. Rita Maria de Souza Couto \\ Orientador \\ Departamento de Artes e Design - PUC-Rio \\ Dr. Luiz Antônio Fernandez Braga \\ Departamento de Comunicação Visual - UFRJ
}

Dra. Roberta Porta Gonçalves Rodrigues

Departamento de Artes e Design - PUC-Rio

Dra. Maria Isabel Peixoto Guimarães

Departamento de Administração - PUC-Rio

Dra. Eliane Jordy lung

Geekie Educação e Tecnologia 
Todos os direitos reservados. A reprodução, total ou parcial do trabalho, é proibida sem a autorização da universidade, do autor e do orientador.

\section{Gilberto Mendes Correia Junior}

Graduou-se em Desenho Industrial, habilitação Produto pela UFRJ em 1990. Especialista em Marketing e Administração de Empresas pela FGV em 1991. MBA em Gestão Empresarial pela FGV em 2008. É professor do curso de Design da PUCRio, Supervisor do Laboratório de Ensino e Experimentos Gráficos PRELO e sócio-diretor da C-Brand, consultoria de Design Estratégico.

Ficha Catalográfica

Mendes Correia Junior, Gilberto

Os CANVAS aplicados ao Design de Serviço: novos conhecimentos para a formação de designers / Gilberto Mendes Correia Junior; orientador: Rita Maria de Souza Couto; coorientador: Luiz Antônio Fernandez Braga. - 2021.

88 f: il. color. ; $30 \mathrm{~cm}$

Dissertação (mestrado) - Pontifícia Universidade Católica do Rio de Janeiro, Departamento de Artes e Design, 2021.

Inclui bibliografia

1. Design de Serviço. 2. Ferramentas CANVAS. 3. Mediação de Conflitos. 4. Design Participativo. 5. Formação de Designers. I. Couto, Rita Maria de Souza. II. Fernandez Braga, Luiz Antônio. III. Pontifícia Universidade Católica do Rio de Janeiro. Departamento de Artes e Design. IV. Título. 


\section{Agradecimentos}

À Julia, amor, companheira e cúmplice deste desafio, e para Vinícius, brilhante e complexo, meu filho querido.

Agradeço aos mestres das escolas e da vida que me ajudaram a chegar até aqui. Posso me considerar privilegiado por ter encontrado tantos em minha jornada. Em especial, alguns que não poderiam passar em branco neste momento de conclusão. Jackeline Farbiarz, por ter dedicado os minutos que não tinha, me orientando sobre os primeiros passos que eu deveria dar em meu mestrado. Izabel Oliveira e Roberta Portas, por terem fertilizado a semente de educador em minha trajetória. Apparecida Mamede, pelas orientações que abriram a minha cabeça para novos campos a explorar. Clarissa Biolchini e Jeferson Soares, por terem sido as pontes para as conversas que tive com profissionais que entrevistrei. Claudio Werneck, meu irmão nesta batalha do dia a dia do mercado de Design, meu sócio na C-Brand. À PUC-Rio pelo apoio em forma de bolsa de isenção de mensalidade. E por último, Luiz Braga, irmão e amigo de mais de 30 anos que me presenteou com o seu tempo e co-orientou esta dissertação, e Rita Couto, uma pessoa especial que me acolheu, me entendeu e me ajudou muito. Uma amiga que terei em novos desafios que estão por vir. A história continua... 


\section{Resumo}

Mendes Correia Junior, Gilberto; Couto, Rita Maria de Souza; Fernandez Braga, Luiz Antônio. Os CANVAS aplicados ao Design de Serviço: novos conhecimentos para a formação de designers. Rio de Janeiro, 2021. 88p. Dissertação de Mestrado - Departamento de Artes e Design, Pontifícia Universidade Católica do Rio de Janeiro.

Esta dissertação tem como objetivo analisar a formação de designers à luz das ferramentas CANVAS na prática do Design de Serviço. A pesquisa buscou as origens dos CANVAS e do Design de Serviço, além de categorizar os principais CANVAS por área mercadológica de aplicação. Realizou-se uma pesquisa quantitativa que para identificar os principais CANVAS utilizados por designers e não designers, os benefícios e as dificuldades que estes encontram no uso desta ferramenta em projetos de Design de Serviço. Num segundo momento, entrevistas semiestruturadas, com profissionais atuantes no segmento de Design de Serviço e usuários de CANVAS, foram analisadas para encontrar as habilidades que designers e não designers necessitam possuir para manejar esta ferramenta em projetos colaborativos. Os resultados destes dois momentos foram consolidados, apontando para três habilidades importantes que designers precisam dominar: a identificar o grau de complexidade do projeto, a entender a forma como o grupo se organiza em sua arquitetura social e ter atenção aos conflitos intragrupais, certos de ocorrerem, pois estes quando tratados de maneira hábil, podem trazer muitas contribuições para processos de criação coletiva.

\section{Palavras-chave}

Design de Serviço; Ferramentas CANVAS; Mediação de Conflitos; Design Participativo; Formação de Designers. 


\section{Abstract}

Mendes Correia Junior, Gilberto; Couto, Rita Maria de Souza (Advisor); Fernandez Braga, Luiz Antônio (Co-Advisor). CANVAS applied to Service Design: new knowledge for the training of designers. Rio de Janeiro, 2021. 88p. Dissertação de Mestrado Departamento de Artes e Design, Pontifícia Universidade Católica do Rio de Janeiro.

This dissertation aims to analyze the training of designers in the light of the CANVAS tools in the practice of Service Design. The research sought the origins of CANVAS and Service Design, in addition to categorizing the main CANVAS by market area of application. A quantitative research was carried out to identify the main CANVAS used by designers and non-designers, the benefits and difficulties they encounter in using this tool in Service Design projects. Secondly, semi-structured interviews, with professionals working in the Service Design segment and CANVAS users, were analyzed to find the skills that designers and non-designers need to have to manage this tool in collaborative projects. The results of these two moments were consolidated, pointing to three important skills that designers need to master: to identify the degree of complexity of the project, to understand the way the group is organized in its social architecture and to pay attention to intragroup conflicts, certain to occur because these, when handled in a skillful way, can bring many contributions to collective creation processes.

\section{Keywords}

Service Design; CANVAS Tools; Conflicts Mediation; Participatory Design; Training Designer. 


\section{Sumário}

1 Introdução 14

$\begin{array}{lll}1.1 & \text { A contextualização } & 14\end{array}$

$\begin{array}{lll}1.2 & \text { O problema } & 15\end{array}$

$\begin{array}{lll}1.3 & \text { O objeto de Estudo } & 15\end{array}$

$\begin{array}{lll}1.4 \text { Os objetivos } & 15\end{array}$

$\begin{array}{lll}1.4 .1 & \text { Objetivo geral } & 15\end{array}$

$\begin{array}{ll}1.4 .2 & \text { Objetivos específicos } \\ 1.5 & 15\end{array}$

$\begin{array}{lll}1.5 & \text { As hipóteses } & 16\end{array}$

$\begin{array}{lll}1.6 & \text { O estado da arte e ineditismo } & 16\end{array}$

$\begin{array}{lll}1.7 & \text { A justificativa e relevância } & 16\end{array}$

$\begin{array}{lll}\text { 1.7.1 Relevância educacional } & 17\end{array}$

$\begin{array}{lll}1.7 .2 & \text { Relevância social } & 17\end{array}$

$\begin{array}{ll}1.7 .3 \text { Relevância acadêmica } & 17\end{array}$

$\begin{array}{lll}1.8 & \text { A visão geral do método } & 17\end{array}$

$\begin{array}{lll}1.9 & \text { O recorte do universo da pesquisa } & 18\end{array}$

$\begin{array}{ll}1.10 \text { O instrumento de pesquisa } & 18\end{array}$

$\begin{array}{ll}1.11 \text { A estrutura da dissertação } & 18\end{array}$

2 O Design de Serviço $\quad 20$

2.1 A origem do Design de Serviço 20

2.2 O que é Design de Serviço 22

2.3 As ferramentas do Design de Serviço 23

3 As ferramentas CANVAS $\quad 25$

$\begin{array}{lll}3.1 & \text { A origem dos CANVAS } & 25\end{array}$

$\begin{array}{ll}3.2 \text { A proliferação dos CANVAS } & 30\end{array}$

$\begin{array}{lll}3.2 .1 & \text { Lean Canvas } & 30\end{array}$

3.2.2 Product/Market Fit Canvas 31

3.2.3 Project Model Canvas 32

3.2.4 Marketing Strategy Canvas 33

3.2.5 Marketing Campaign Model Canvas 34

3.2.6 Customer Journey Canvas 34

3.2.7 Business Model You 37

3.2.8 Corporate Innovation Canvas 39

3.2.9 T\&D Canvas 41

3.3 Os CANVAS e suas Aplicações 41

4 As Experiências com os CANVAS $\quad 44$

4.1 O primeiro momento da investigação 44

4.2 O segundo momento da investigação 49

4.2.1 A análise das entrevistas $\quad 52$

4.2.1.1 Sobre os CANVAS que usa 52

4.2.1.2 Sobre a frequência que utiliza os CANVAS 56

4.2.1.3 A interação de profissionais na utilização dos CANVAS 57 
4.2.1.4 Sobre o tipo de projeto que utiliza o CANVAS 60

4.2.1.5 Sobre as dificuldades na utilização dos CANVAS 62

4.2.1.6 Sobre as críticas que geralmente são feitas aos CANVAS 64

4.2.1.7 Sobre as melhorias para tornar o CANVAS mais eficiente 64

4.2.1.8 Sobre a importância dos CANVAS para o projeto 66

5 O mercado e a sala de aula: oportunidades a serem exploradas na formação de designers $\quad 69$

$\begin{array}{lll}5.1 & \text { A prática de mercado do design de serviço } & 69\end{array}$

$\begin{array}{lll}5.2 & \text { A habilidade para mediar conflitos } & 71\end{array}$

$\begin{array}{lll}5.3 & \text { A prática da sala de aula } & 76\end{array}$

5.3.1 As definições da prática da atuação do Design 76

5.3.2 As disciplinas realizadas em grupo no curso de Design 78

$\begin{array}{ll}\text { 5.3.3 Conflitos nas disciplinas do curso de Design } & 79\end{array}$

6 Conclusões e recomendações da dissertação $\quad 81$

$\begin{array}{ll}\text { Referências bibliográficas } & 85\end{array}$

$\begin{array}{ll}\text { A Published paper } & 88\end{array}$ 


\section{Lista de figuras}

Figura 1.1 Mapa Estratégico da Dissertação 19

Figura 2.1 Blueprint para serviço de atendimento por telefone as $\begin{array}{ll}\text { corretoras de valores } & 21\end{array}$

$\begin{array}{llr}\text { Figura 3.1 Diagrana PERT } & 26\end{array}$

$\begin{array}{lll}\text { Figura 3.2 Diagrana CPM } & 27\end{array}$

Figura 3.3 Mapa Estratégico BSC 28

$\begin{array}{lll}\text { Figura 3.4 The Business Model Canvas } & 29\end{array}$

Figura 3.5 Lean Canvas 31

Figura 3.6 PMF Canvas 33

$\begin{array}{lll}\text { Figura 3.7 } & \text { PM Canvas } & 34\end{array}$

Figura 3.8 MS Canvas $\quad 35$

Figura 3.9 MC2 Canvas $\quad 36$

Figura 3.10 CJ Canvas 37

Figura 3.11 CJ Canvas 38

Figura 3.12 Business Model You 39

Figura 3.13 Corporate Innovation Canvas 40

Figura 3.14 T\&D Canvas 42

Figura 4.1 Concentração de profissionais por segmento de atuação. 45

$\begin{array}{lll}\text { Figura 4.2 Campos de dificuldades nos CANVAS para designers. } & 47\end{array}$

Figura 4.3 Profissionais que interagem nas atividades com os CANVAS. (Fonte: o autor) 49

Figura 4.4 Value Proposition Canvas. $\quad 53$

Figura 4.5 Value Proposition Canvas integrado ao BMC. 54

Figura 4.6 Duplo Diamante. 60

$\begin{array}{lll}\text { Figura 5.1 Processo projetual do Co-Design } & 75\end{array}$ 


\section{Lista de tabelas}

Tabela 3.1 Sumário dos CANVAS Apresentados (Fonte: o autor) 43

Tabela 4.1 Nível de formação dos respondentes (Fonte: o autor) 46

Tabela 4.2 Graduação dos respondentes (Fonte: o autor) 46

Tabela 4.3 Tempo de formação dos respondentes (Fonte: o autor) 46 


\section{Lista de Abreviaturas}

BMC - Business Model Canvas

PMF - Product/Market FIT

BSC - Balanced Scoredcard

PMC - Project Model Canvas

MC2 - Marketing Campaign Model Cancas

BMY - Business Model You

PERT - Program Evaluation and Review Technique

CPM - Critical Path Method

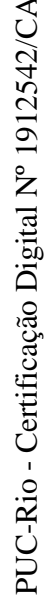

VPD - Value Proposition Design

UX - User Experience

FCS - Fatores Críticos de Sucesso

MVP - Minimum Viable Product

PMI - Project Management Institute

ROI - Return on Investment

KISD - Köln International School of Design

POC - Proof of Concept

TI - Tecnologia da Informação CES - Câmara de Educação Superior

CNE - Conselho Nacional de Educação 
"Mestre não é quem sempre ensina, mas quem de repente aprende".

João Guimarães Rosa, Grande Sertão: Veredas. 


\section{Introdução}

\section{1}

\section{A contextualização}

Novos conhecimentos vêm sendo demandados aos designers na atualidade. Um exemplo é o desafio de lidar com novas habilidades para aqueles que buscam atuar no segmento de Design de Serviço. Com isto, para formar profissionais e atualizar os que já se encontram em atuação no mercado, novos conteúdos necessitam ser introduzidos nesta formação. Isto pode ser constatado quando observamos as ferramentas CANVAS, amplamente utilizadas em projetos de Design de Serviço.

As ferramentas CANVAS buscam simplificar o entendimento das engrenagens de um modelo de negócio, conferindo uma visão holística aos que se utilizam destas, mas também exigem formação multidisciplimar para que seja possível explorar plenamente os seus benefícios. A capacidade de síntese, necessária para o bom uso das ferramentas CANVAS, expõe fragilidades no campo do conhecimento e nas habilidades dos que as utilizam, profissionais de diversos campos do saber, dentre eles os designers. Esta fragilidade pode tornar a utilização das ferramentas CANVAS pouco eficazes, mecanizando as resposta que a ferramenta solicita. Uma consequência deste uso inadequado desvirtua o benefício estratégico que os CANVAS oferecem para questões complexas de um modelo de negócio.

Nos campos dos CANVAS associados ao management, tais como "Fontes de Receita", "Estrutura de Custo", "Métricas", "Parceiros Estratégicos", "Segmentação de Público", "R.O.I.", "Promoção", "Distribuição", podem trazer aos designers dificuldades no entendimento, e consequentemente propostas intuitivas, pouco estruturadas, que impossibilitam a implementação da contribuição dos caminhos propostos pelo uso desta ferramenta.

Os CANVAS ganharam espaço na prática do Design de Serviço, e este crescimento pode ser constatado ao observarmos a variedade de CANVAS que a presente pesquisa levantou, mostrando a sua utilização para diversas finalidades e segmentos de atuação.

Diante deste cenário, observei que havia encontrado a inspiração para 
o tema de minha dissertação: OS CANVAS APLICADOS AO DESIGN DE SERVIÇO: NOVOS CONHECIMENTOS PARA A FORMAÇÃO DE DESIGNERS.

\section{2}

\section{O problema}

Observando-se o acima exposto, podemos resumir o problema da pesquisa nas seguintes questões a serem investigadas:

- Quais conhecimentos devemos introduzir na formação de designers que desejam trabalhar no segmento de Design de Serviços?

- Como introduzir estes novos conhecimentos na formação de designers sem que ocorra incremento excessivo no conteúdo de sua graduação?

- Em quais disciplinas, na formação atual, podemos agregar os conteúdos necessários?

- Quais recortes destes conteúdos são necessários para que o designer faça bom uso de ferramentas CANVAS?

\section{3}

\section{O objeto de Estudo}

A utilização dos CANVAS quando aplicados em projetos de Design de Serviço.

\section{4}

\section{Os objetivos}

\subsection{1}

\section{Objetivo geral}

Identificar necessidades a serem introduzidas na formação de designers, à luz das ferramentas CANVAS, para a prática do Design de Serviço.

\section{4 .2}

\section{Objetivos específicos}

- Identificar, descrever e classificar os CANVAS utilizados pelos designers, enriquecendo e ampliando as discussões sobre a experiência da ferramenta.

- Identificar o perfil de formação dos profissionais que trabalham com Design de Serviço e utilizam ferramentas de CANVAS. 
- Identificar as dificuldades de uso das ferramentas CANVAS quando utilizadas por designers no segmento de Design de Serviço.

- Identificar a relevância da ferramenta CANVAS no processo de pensamento do Design.

\section{5}

\section{As hipóteses}

As ferramentas CANVAS facilitam o entendimento das engrenagens de um modelo de negócio no momento em que estes são concebidos por profissionais de múltiplas áreas de conhecimento, dentre eles os designers. Estas ferramentas possuem as suas origens de construção no campo da gestão de negócios, trazendo para o processo questões pouco abordadas durante a formação acadêmica de designers.

A pouca familiaridade com estas questões pode transformar a atuação de designers superficial, tendo a geração de insights o objetivo de sua participação no segmento de Design de Serviço. Entretanto, a contribuição do Design pode ir muito além, havendo campos oportunos a serem desenvolvidos e os quais necessitam ser evidenciados no percurso de sua formação.

\section{6}

\section{0 estado da arte e ineditismo}

Várias publicações e estudos vem sendo realizados sobre a utilização de CANVAS observando o aspecto de sua prática e utilização em projetos de Design de Serviço. Entretanto, o olhar para estas ferramentas com a intenção de aprimorar a formação de novos designers é inédita.

Este trabalho fará uma crítica sobre a forma como os CANVAS vem sendo utilizados por designers, visando identificar os ajustes que se fazem necessários na sua formação para que estes façam o bom uso da ferramenta em projetos de Design de Serviço.

\section{7}

\section{A justificativa e relevância}

Os CANVAS são ferramentas que facilitam o entendimento e as relações que existem entre as áreas que necessitam ser pensadas para que consigamos construir um Modelo de Negócio. Estas ferramentas também servem para integrar a equipe de desenvolvimento, evidenciando os fatores críticos a serem trabalhados como proposta de valor na experiência do usuário com o produto ou serviço. 
Os projetos de Design de Serviço consistem na aplicação dos conhecimentos e abordagem do Design para a criação, evolução e gerenciamento de grupos de pessoas, tanto na elaboração, como na implementação e operação de algo. Desta forma torna-se fundamental agregar conhecimentos no campo da gestão de negócios, também conhecido como management, para que os designers desempenhem adequadamente esta nova função.

Com isto, faz-se necessário identificar os novos campos de conhecimento que designers necessitam adquirir em sua formação acadêmica, na medida de sua necessidade, para que estes consigam atuar de forma mais segura junto a times multidisciplinares.

\subsection{1}

\section{Relevância educacional}

Com a realização deste trabalho, poderemos identificar os ajustes necessários a serem feitos nos conteúdos de disciplinas no curso de Design, buscando melhor atender as necessidades de formação para os estudantes que procuram atuar no segmento de Design de Serviço.

\subsection{2}

\section{Relevância social}

Por se tratar de um estudo que visa formar designers mais aptos a prática profissional, a pesquisa contribuirá para incrementar o conhecimento para os que lecionam e praticam o Design, trazendo maior qualidade e valor agregado aos projetos de Design de Serviço, quando estes são colocados em uso pela sociedade.

\subsection{3}

\section{Relevância acadêmica}

A pesquisa mapeará as necessidades de novas competências que estão sendo atribuídas ao Design, contribuindo para a melhoria do ensino acadêmico, enriquecendo as disciplinas (dentre elas as de Projeto) presentes no curso de Design na PUC-Rio.

\section{8}

\section{A visão geral do método}

A pesquisa mapeará a relação dos CANVAS com os designers que atuam em projetos de Design de Serviços. Para isto, o método está dividido em dois momentos da pesquisa conforme abaixo descritos: 
MOMENTO 1 - PESQUISA QUANTITATIVA utilizando questionários on line na plataforma SURVIO para identificar os CANVAS mais utilizados por profissionais que trabalham no segmento de Design de Serviços, designers e não designers, os segmentos de mercado de aplicação do Design de Serviço, os benefícios dos CANVAS, o perfil dos profissionais que interagem com a ferramenta, dentre outras questões;

MOMENTO 2 - PESQUISA QUALITATIVA, utilizando entrevistas semiestruturadas para identificar o entendimento das ferramentas CANVAS, as dificuldades na sua utilização, a frequência que utilizam, críticas e sugestões, dentre outros aspectos;

\section{9}

\section{0 recorte do universo da pesquisa}

A pesquisa abordará designers que atuam no segmento de Design de Serviço, estabelecidos nos estados do Rio de Janeiro e São Paulo, para compreender a percepção destes quanto à utilização das ferramentas CANVAS em seus projetos.

\subsection{0 \\ 0 instrumento de pesquisa}

- Aplicação de questionários on-line na fase da pesquisa quantitativa.

- Realização de entrevistas semiestruturadas na fase da pesquisa qualitativa.

\subsection{1}

\section{A estrutura da dissertação}

No segundo capítulo discorro sobre o Design de Serviço, identificando as suas origens, a sua definição como prática e as ferramentas que são oferecidas para a sua prática.

No terceiro capítulo, abordo a origem dos CANVAS, elencando os tipos de CANVAS encontrados e as suas aplicações no mercado. Para a elaboração deste capítulo foi necessária a realização de um levantamento descritivo elencando os CANVAS mais citados em literatura específica sobre o tema. Também priorizei os segmentos de mercado onde os CANVAS estão sendo utilizados com base no resultado da pesquisa quantitativa realizada nos estados do Rio de Janeiro e São Paulo.

No quarto capítulo a experiência que os designers, e não designers possuem com os CANVAS é refinada. As entrevistas semiestruturadas dão o conteúdo deste capítulo, revelando o entendimento da ferramenta na prática de 
se projetar, as dificuldades, a frequência que usam os CANVAS e as sugestões de melhorias que podem ser realizadas para tornar a ferramenta mais eficiente.

Para o quinto capítulo reservo trazer a prática de mercado e as oportunidades que poderão ser exploradas no processo de formação de designers.

No sexto, e último capítulo, descrevo as conclusões deste estudo, com interpretações e análises dos achados da pesquisa, resultando em proposições das práticas que poderão ser implementadas na formação de designers, para aprimorar a sua atuação na área de Design de Serviço.

A Figura 1.1 é um mapa que descreve a visão estratégica da desta dissertação.

\section{VISÃO ESTRATÉGICA E ESTRUTURAL DA DISSERTAÇÃO}

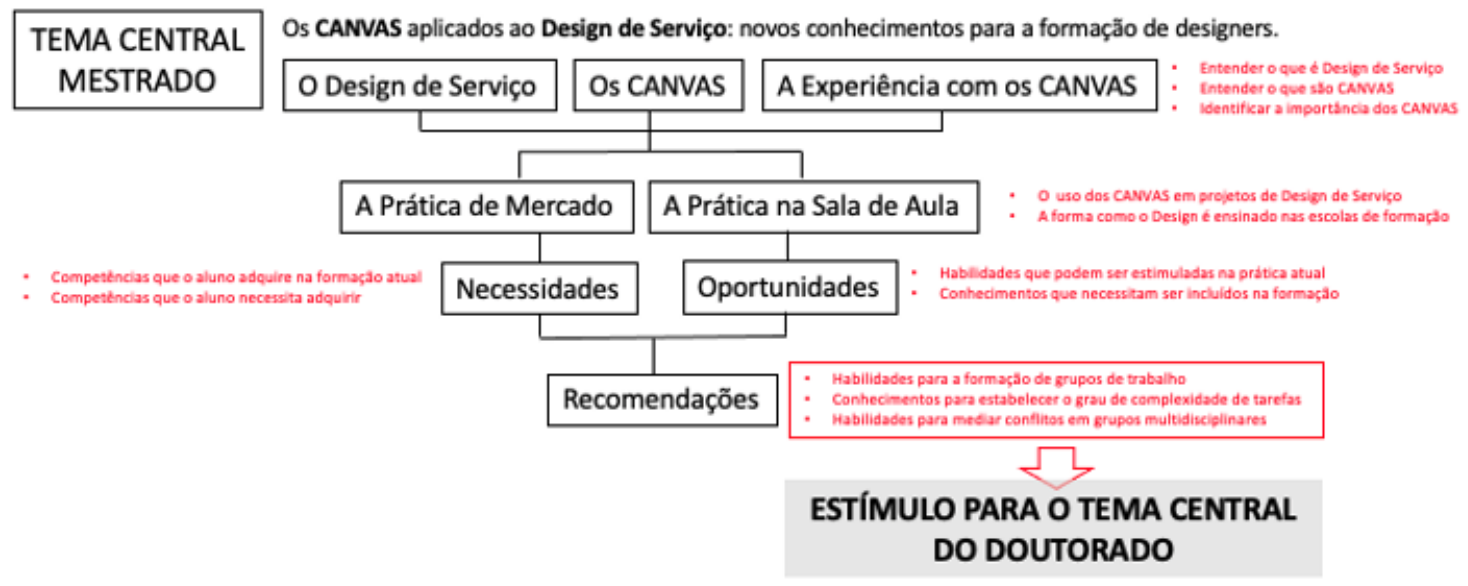

Figura 1.1: Mapa Estratégico da Dissertação Fonte: o Autor 


\section{2}

\section{O Design de Serviço}

\section{1}

\section{A origem do Design de Serviço}

Neste capítulo trataremos sobre o Design de Serviço, fazendo uma retrospectiva de sua história: como, quando e porque começou a ter interesse para o mercado, na busca de entender a presença das ferramentas CANVAS como necessárias para a sua prática.

O Design de Serviço se aproxima das áreas de business, administração e marketing, pois a sua prática consiste em organizar pessoas, desenvolver infraestrutura, formatar a comunicação e aprimorar os componentes materiais para um serviço, de forma a melhorar a qualidade na interação entre a empresa prestadora do serviço e os consumidores que se beneficiam deste serviço.

A melhoria da qualidade dos serviços também inspirou G. Lynn Shostack $^{1}$, que desenvolveu um método em 1984 para a modelagem de serviços sob a perspectiva da experiência do cliente e das pessoas que estão envolvidas na sua execução. Este método teve como consequência a construção da ferramenta Service Blueprint, utilizada até a atualidade como apoio para projetos de Design de Serviço.

Nessa ferramenta gráfica, uma linha separa as partes visíveis e não visíveis pelos clientes de um serviço, tendo como objetivo representar as etapas do processo necessárias para que o serviço ocorra, assim como dar clareza a complexidade que está por detrás da experiência que se pretende oferecer. À medida que uma estrutura é projetada no Service Blueprint, torna-se possível dimensionar a infraestrutura necessária à operação, as etapas da execução do serviço, os pontos críticos do processo, os custos envolvidos e, por consequência, a rentabilidade do serviço proposto. A Figura 2.1 é um exemplo de um Service Blueprint para um serviço de atendimento a corretoras de valores por telefone. Neste diagrama percebe-se a proporção entre a parte visível ao cliente e a complexidade envolvida para que a entrega do serviço ocorra. Podemos

${ }^{1}$ G. Lynn Shostack era vice-presidente do Citybank quando escreveu o artigo "Designing Services That Deliver" para a edição do Harvard Business Review em janeiro/fevereiro de 1984. [4] 
considerar que o Design de Serviço se inspirou nesta referência para modelar a sua forma de atuação no mercado.

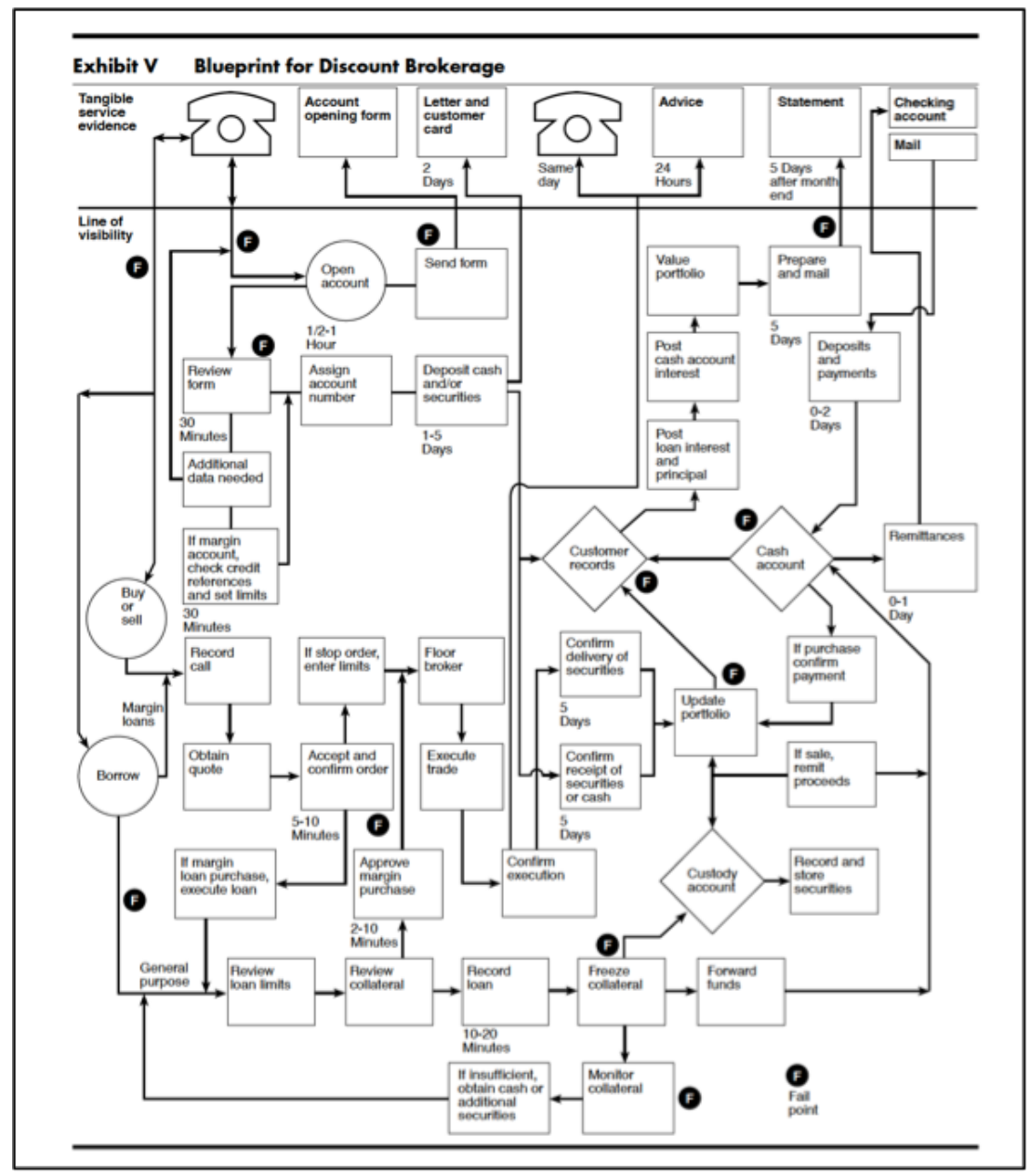

Figura 2.1: Blueprint para serviço de atendimento por telefone as corretoras de valores

Fonte: Harvard Business Review

Por outro lado, o Design de Serviço surgiu como disciplina de estudo associada ao Design em 1991 na Köln International School of Design (KISD), em Colônia, Alemanha. Esta associação foi proposta por Michael Erlhoff, professor e reitor fundador desta instituição, que organizou uma rede composta por profissionais e três universidades, criando núcleos para estudar este novo campo do Design e tornando visível o Design de Serviço, principalmente, para a comunidade acadêmica. Os principais núcleos de pesquisa se concentraram na Alemanha na KISD, no Reino Unido na Westminster Business School (University of Westminster) e no Politécnico di Milano, na Itália. A partir deste núcleo, o Design de Serviço se estruturou como formação de profissionais para a sua prática.

Outra referência cronológica do Design de Serviço data de 2001 com a 
fundação da Livework Studio London, que tinha como proposta ser uma consultoria especializada em Design de Serviço formada por uma equipe multidisciplinar com designers de serviço, business designers, facilitadores, pesquisadores e consultores eventuais. Alguns anos depois, em 2004, foi criada a Service Design Network, uma instituição sem fins lucrativos que vem buscando impulsionar a prática do Design de Serviço através de eventos e publicações, unindo uma rede global de profissionais para compartilhamento de conhecimento, colaboração e troca de experiências de mercado.

\section{2}

\section{0 que é Design de Serviço}

Quando em 2001 o Studio Livework London apresentou ao mercado a sua proposta de atuação como consultoria especializada em Design de Serviço, a definição desta prática se configurou da seguinte forma, numa tradução livre para o português:

O Design de Serviço é uma nova combinação de práticas existentes, novos termos, valores atuais e métodos e habilidades envolvidos, fundados nas disciplinas tradicionais de design. Como parte da pesquisa, participamos da definição dessa prática [1].

Tomando por base a definição atual da atividade segundo o Service Design Network, podemos considerar o seguinte:

Design de serviços é a prática de projetar serviços. Ele usa uma abordagem holística e altamente colaborativa para gerar valor para o usuário e o provedor de serviços durante todo o ciclo de vida do serviço. Na prática, o design de serviços ajuda a coreografar os processos, tecnologias e interações que conduzem a entrega dos serviços, usando uma perspectiva centrada no ser humano. Hoje, o design de serviço é aplicável em vários setores, ajudando a fornecer objetivos estratégicos e táticos para o setor público e privado [5].

Sob essa perspectiva, podemos considerar que a atividade de Design de Serviço consiste em planejar e organizar os recursos de uma empresa, sejam eles humanos, financeiros, materiais e imateriais, para melhorar diretamente a maneira como os serviços são prestados e, consequentemente, melhorar a experiência do usuário nos pontos de contato deste com o serviço.

A promessa desta atuação traz ao Design de Serviço uma complexidade de critérios a serem consideradas, multifatoriais e transdisciplinares em sua maioria. O desempenho da função não requer apenas bons insights mediante 
observação do comportamento do usuário obtidos por dinâmicas de ideação. O Design de Serviço busca alinhamento entre o modelo de negócio de uma empresa e o serviço que se pretende prestar, elaborando sistemas que necessitam estar operantes para fornecer o serviço adequadamente durante o seu ciclo de vida. Através de seu método, os elos fracos ou em desalinhamento com a proposta de valor do serviço são identificados e, de forma colaborativa, são repensados e integrados ao ecossistema existente.

O Design de Serviço também busca mapear todo o ciclo de processos internos, trazendo uma visão panorâmica e permitindo otimizar os recursos que muitas das vezes encontram-se duplicados em estruturas complexas, causando desperdício de recursos. Além disso, o Design de Serviço possui caráter humanista em sua forma de atuar, podendo transformar o ambiente corporativo em algo mais participativo, integrado e operativo.

\section{3}

\section{As ferramentas do Design de Serviço}

O Design de Serviço cria valor em suas iniciativas buscando entender os elementos tangíveis e intangíveis envolvidos na evidência de um serviço. É uma forma de tornar visível a invisibilidade do mesmo, tornando evidente para o usuário aquilo que o serviço promete. Segundo Stickdorn, M. at al (2017) o Design de Serviço, possui seis princípios[2]:

1. Centrado no humano - deve considerar todas as pessoas afetadas pelo serviço;

2. Colaborativo - as partes interessadas no serviço, com suas respectivas funções, devem estar ativamente envolvidas no processo de design do serviço;

3. Iterativo - é um processo exploratório, adaptativo e com abordagem experimental, realizando iterações ao longo do processo de implementação;

4. Sequencial - o serviço deve ser compreendido, visualizado e orquestrado como uma sequência de ações inter-relacionadas;

5. Real - as necessidades devem ser pesquisadas na realidade, as ideias prototipadas e os valores intangíveis evidenciados como realidade física ou digital;

6. Holístico - o serviço deve atender de forma sustentável às necessidades de todas as partes interessadas por todo o serviço e em toda a empresa. 
Para que estes seis princípios ocorram, o Design de Serviço se apropria de ferramentas, muitas delas em forma de mapas de visualização, quer para organizar dados, gerar interação entre os membros de uma equipe de trabalho momento de ideação, construir fluxos de processos, mapear zonas que possam gerar conflitos no interesse das partes interessadas e clarear o ecossistema do negócio como um todo.

Dentre as diversas ferramentas que o |designer utiliza para o desenvolvimento de projetos no campo do Design de Serviço, os CANVAS são apresentados como uma referência importante, ajudando a converter conceitos de serviços em processos de negócios, segundo o Design Council UK na publicação Design Methods for a Developing Services[28].

As ferramentas CANVAS ajudam a identificar os pontos fundamentais para algo que desejamos aplicar nossos recursos materiais e imateriais, tendo por fio condutor questões relacionadas ao valor que está sendo criado à identificação de quais problemas estão ajudando as pessoas a resolvê-los, à forma de entrega do valor que será criado, a identificação do que será preciso ter a fazer para atingir eficiência naquilo que será entregue. Por fim, estas ferramentas permitem que seja ponderada a sustentabilidade da forma de remuneração de um negócio, considerando a quantidade de esforços versus a retenção de valor financeiro que poderá ser gerado a medida em que o negócio se desenvolverá.

Desta forma, as ferramentas CANVAS são utilizadas no Design de Serviço servindo de base para profissionais de diversas áreas de interesse e saberes encontrem os melhores caminhos a serem percorridos, da concepção à implementação do que está sendo projetado.

No capítulo seguinte serão apresentados os tipos de CANVAS e suas particularidades quanto ao formato e utilização na prática profissional. 


\section{3}

\section{As ferramentas CANVAS}

O presente capítulo apresenta as origens das ferramentas CANVAS e os principais tipos de CANVAS encontrados no mercado. A escolha dos CANVAS se deu por um levantamento descritivo elencando os CANVAS mais citados em literatura específica sobre o tema.

\section{1}

\section{A origem dos CANVAS}

A primeira ferramenta CANVAS surgiu como uma proposta para que empresários e executivos conseguissem visualizar, discutir e avaliar, como um negócio seria executado de forma sistêmica, integrando necessidades complementares durante a etapa de sua concepção. Esta foi a motivação de Alexander Osterwalder, em seus estudos de doutorado, defendido na l'Ecole des Hautes Etudes Commerciales, também conhecida por HEC Lausanne na Suíça, em 2004. A tese que teve como título "A Ontologia do Modelo de negócio - uma proposição de uma abordagem da ciência do Design" [3], buscava encontrar e fornecer a base para uma ferramenta gerencial que permitisse a uma empresa expressar facilmente a sua lógica de funcionamento como negócio.

No resumo introdutório do seu trabalho, Osterwalder argumenta que a base metodológica para obter o resultado esperado está na ciência do Design, onde se busca, através de um artefato construído, resolver um problema específico para um usuário. Nesse caso, o artefato proposto por Osterwalder fornece uma ontologia de um modelo de negócio, que permite explicitar a estrutura necessária para que o negócio de uma empresa funcione adequadamente. A tese resultou num protótipo de um software, utilizado para trazer mais clareza às empresas na descrição formal de sua proposta de valor, seus clientes, o relacionamento com eles, a infraestrutura intra e inter-empresa necessárias e seu modelo de lucro. Até então, nenhum modelo de ferramenta existente permitia expressar a lógica de uma empresa do ponto de vista puro dos seus negócios.

Entretanto, ferramentas que buscam visualizar graficamente um negócio, em forma de diagrama, ou até mesmo o comportamento de serviços no campo da administração e negócios, existem há algum tempo. Os gráficos de PERT (Program Evaluation an Review Technique) e CPM (Critical Path Method) 
criados nos anos 1950, auxiliavam os projetos, verificando os caminhos críticos durante a sua implementação.A Figura 3.1 ilustra o diagrama de PERT e a Figura 3.2 ilustra um diagrama CPM.

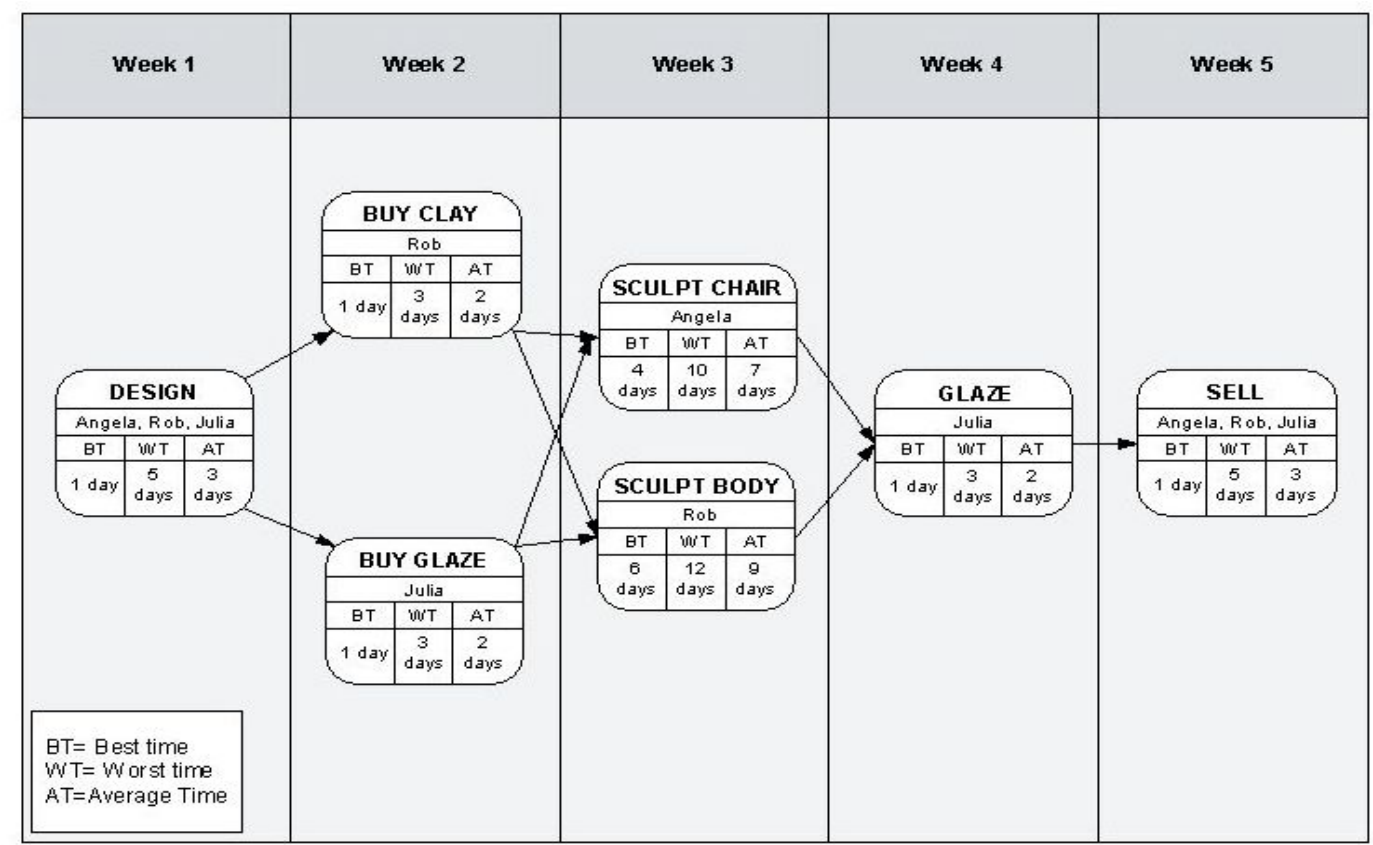

Figura 3.1: Diagrana PERT

Fonte:www. smartdraw.com

Acredito que o Blueprint, citado no capítulo anterior, criado por G. Lynn Shostack em 1983, buscou inspiração nestas duas referências, pois são excelentes modelos para analisar situações que ainda estão por vir, próprias do cenário projetual.

Outra ferramenta anterior ao CANVAS de Osterwalder é o Mapa Estratégico Balanced Scorecard (BSC) [6] [7] [8], criado por Robert Kaplan e David Norton em 1992, que serve para organizações desenvolverem a medição de desempenho para a implementação da estratégia por seu corpo executivo. A Figura 3.3 ilustra o uso do Mapa Estratégico BSC dividindo suas quatro perspectivas estratégicas: Perspectiva Financeira, Perspectiva dos Clientes, Perspectiva dos Processos e Perspectivas de Crescimento e Aprendizado.

As ferramentas Blueprint e o Mapa Estratégico BSC, ainda são usadas até hoje por empresas de diversos portes e segmentos de mercado. Conforme citado em sua tese [3], Osterwalder teve inspiração no Mapa Estratégico do Balanced Scorecard para identificar quatro áreas principais que constituem a essência de um negócio, que posteriormente se desdobraram em nove campos presentes em seu CANVAS. 


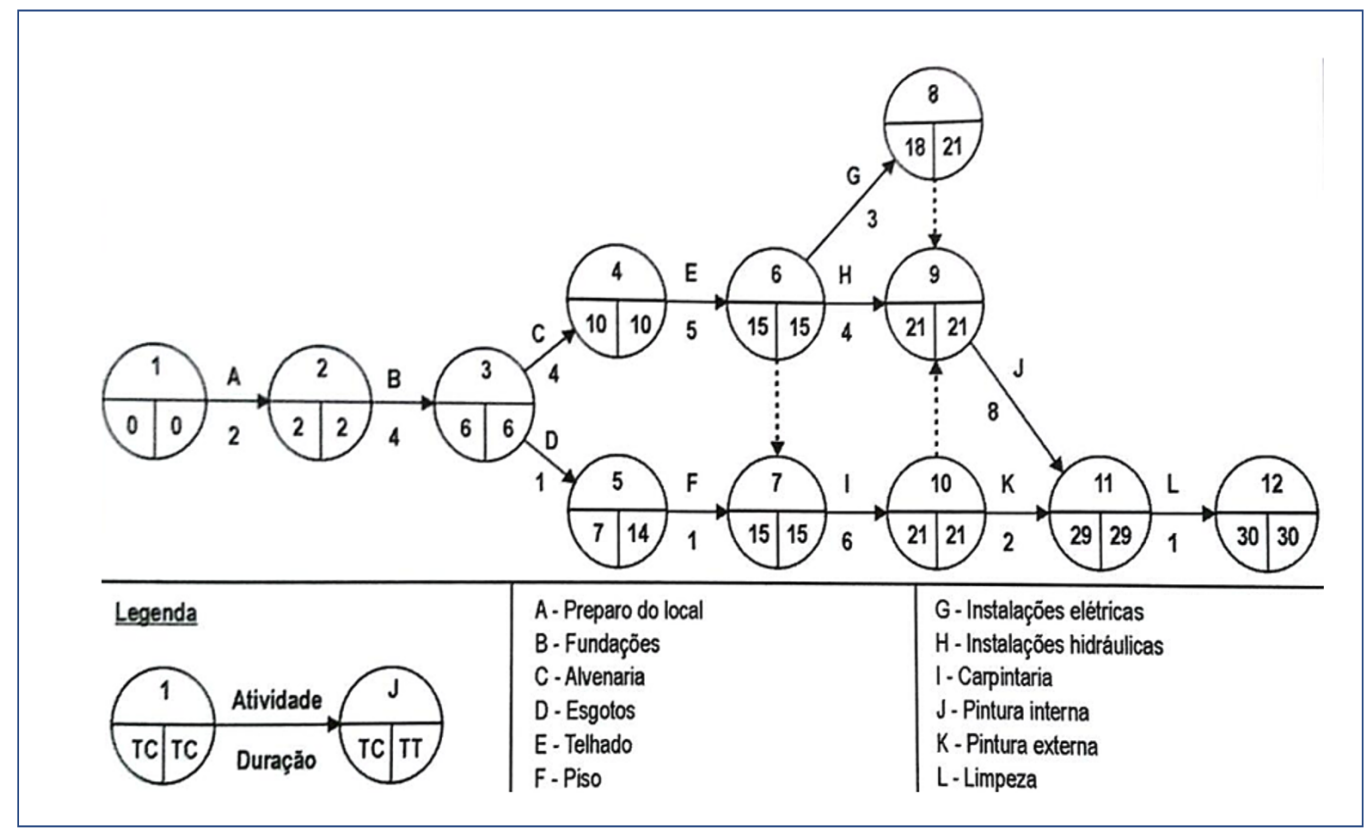

Figura 3.2: Diagrana CPM

Fonte:www.guiadeengenharia.com.br

Em 2009, Alexander Osterwalder, com a ajuda de Yves Pigneur e de mais de 470 colaboradores de 45 países, gestores e consultores em sua maioria, criaram um modelo de ferramenta que utiliza a linguagem visual no formato que conhecemos como BMC (Business Model Canvas) [9]. O BMC elenca nove elementos essenciais para estruturar todo e qualquer modelo de negócio. Os elementos são os seguintes, com as suas devidas perguntas norteadoras:

1. Proposta de valor

- Que valor entregamos ao cliente?

- Qual problema do cliente ajudamos a resolver?

- Que pacote de produtos e serviços estamos oferecendo a cada segmento de clientes?

- Que necessidade de clientes satisfazemos?

2. Segmento de Clientes

- Para quem estamos criando valor?

- Quem são nossos clientes mais importantes?

3. Canais de distribuição

- Por meio de que canais queremos chegar aos segmentos de clientes?

- Como estamos chegando a eles? 


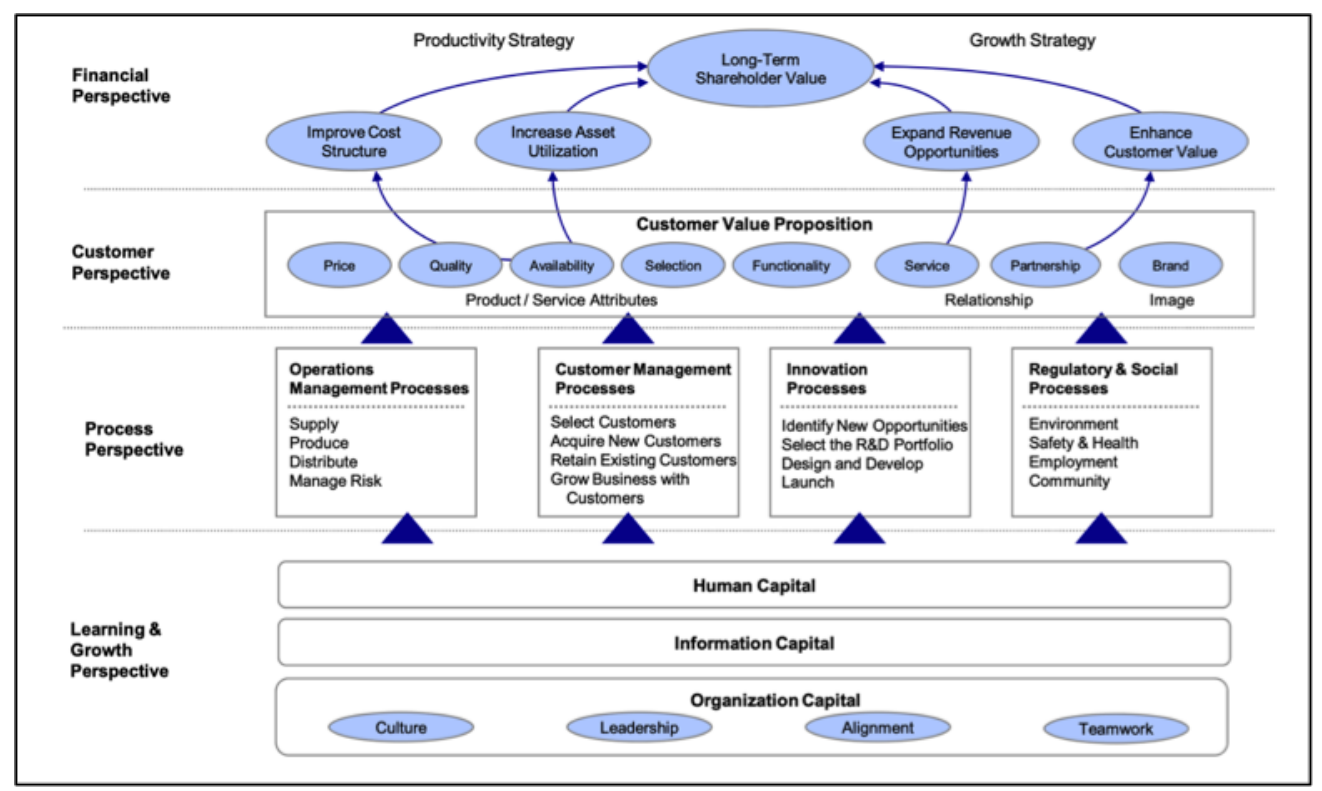

Figura 3.3: Mapa Estratégico BSC

Fonte: Harvard Business School

- Nossos canais estão integrados?

- Quais funcionam melhor?

- Quais são os mais eficientes em termos de custos?

4. Relacionamento com clientes

- Que tipo de relação cada um de nossos segmentos de clientes espera que estabeleçamos e mantenhamos com eles?

- Quais destas relações nós já estabelecemos?

- Como estas relações se integram ao restante do modelo de negócio?

- Quanto nos oneram?

5. Fontes de receita

- Que valor nossos clientes estão realmente dispostos a pagar?

- Quanto pagam hoje?

- Como pagam?

- Em que medida cada fonte de receita contribui para a receita total?

6. Recursos principais

- Que recursos chaves nossas propostas de valor requerem?

- Que recursos nossos canais de distribuição requerem?

- Que relações com os clientes requerem?

- Quais fluxos de receitas são necessários para a sustentabilidade do negócio? 
7. Atividades-chave

- Que atividades-chave nossas propostas de valor requerem?

- Que atividades chave nossos canais de distribuição requerem?

- Que atividades as relações com os clientes requerem?

- Quais fluxos de receita o negócio necessita para operar?

8. Parcerias principais

- Quem são nossos parceiros-chave?

- Quem são nossos fornecedores-chave?

- Que recursos-chave obtemos dos parceiros?

- Que atividades-chave os parceiros realizam?

9. Estrutura de custo

- Quais são os custos mais importantes inerentes ao nosso modelo de negócio?

- Quais são os recursos-chave mais caros?

- Quais são as atividades-chave mais caras?

A Figura 3.4 ilustra o BMC em sua versão atual.

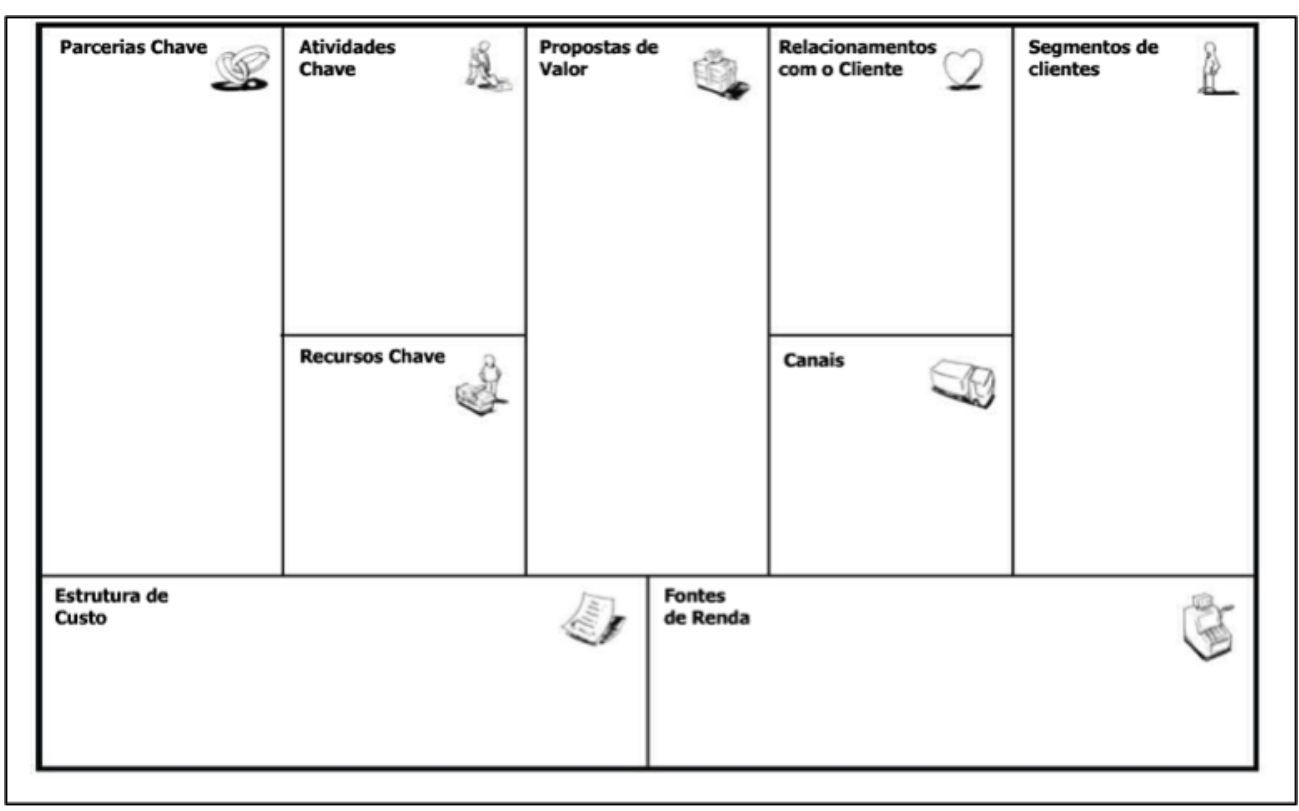

Figura 3.4: The Business Model Canvas Fonte:www. strategyzer.com

O uso da ferramenta BMC está descrito no livro "Business Model Generation, inovação em modelos de negócio" [9]. A co-criação do conteúdo trouxe várias contribuições à ferramenta original, além de colocar em teste um 
dos compromissos do BMC que é ser uma ferramenta para o uso em qualquer tipo de negócio.

O BMC tornou-se muito popular entre empreendedores e grandes empresas como General Eletric, Procter\&Gamble e 3M e também foi aplicado em mercados orientais, especialmente China, Coréia e Japão, segundo a revista HSM Management de julho/agosto de 2013 [10].

Com a popularidade alcançada pelo BMC, podemos assumir que este foi o primeiro CANVAS a inspirou outros autores a criarem ferramentas de propósito semelhante, ou complementares, utilizadas por empreendedores para modelar produtos ou serviços novos, e também para a melhoria de algo existente, que necessite ser repensados para que continue tendo serventia para os seus usuários.

\section{2}

\section{A proliferação dos CANVAS}

Em levantamento realizado no período que compreendeu a elaboração desta dissertação, de 2018 a 2020, foram encontradas mais de 50 ferramentas que são consideradas CANVAS pelos seus autores e divulgadores. No presente trabalho, apresento 9 CANVAS, selecionados por terem sido citados nas entrevistas realizadas com profissionais que trabalham com Design de Serviço. Todos os CANVAS apresentados a seguir citam o BMC como a ferramenta que serviu de inspiração. Alguns destes CANVAS classificados não possuem um autor, tampouco uma referência bibliográfica, sendo, portanto disponibilizados on-line em sites da internet. Os CANVAS apresentados a seguir são: Lean Canvas; Product/ Market FIT Canvas (PMF Canvas); Project Model Canvas; Marketing Strategy Canvas; Marketing Campaign Model Canvas (MC2); Customer Journey Canvas; Business Model You; Corporate Innovation Canvas; T\&D Canvas.

\subsection{1}

\section{Lean Canvas}

O Lean Canvas [10], criado em 2011 por Ash Maurya, é uma ferramenta muito semelhante ao BMC, com maior ênfase em hipóteses que precisam ser validadas antes que um negócio tome forma. Portanto, o Lean Canvas se tornou indispensável na vida de quem atua no segmento de startup.

As startups são empresas em formação, com custo baixo de operação e com grande potencial de crescimento e geração de receita com produtos e serviços inovadores para o mercado. Em sua maioria, as startups buscam investidores anjos, que possibilitam viabilizar suas invenções. Para isto, as 
statups precisam ser assertivas no que estão propondo, deixando claras as expectativas de sucesso e o retorno sobre o capital do investidor anjo.

A ferramenta Lean Canvas substitui quatro dos nove campos da ferramenta original do BMC, pois o objetivo é avaliar campos de maior risco nas startups. Foram adicionados os campos Vantagem Competitiva, Métricas, Solução e Problema, e removidos os campos Relacionamento com clientes, Atividades-Chave, Recursos Principais e Parcerias Principais.

A Figura 3.5 ilustra o Lean Canvas em seu formato atual.

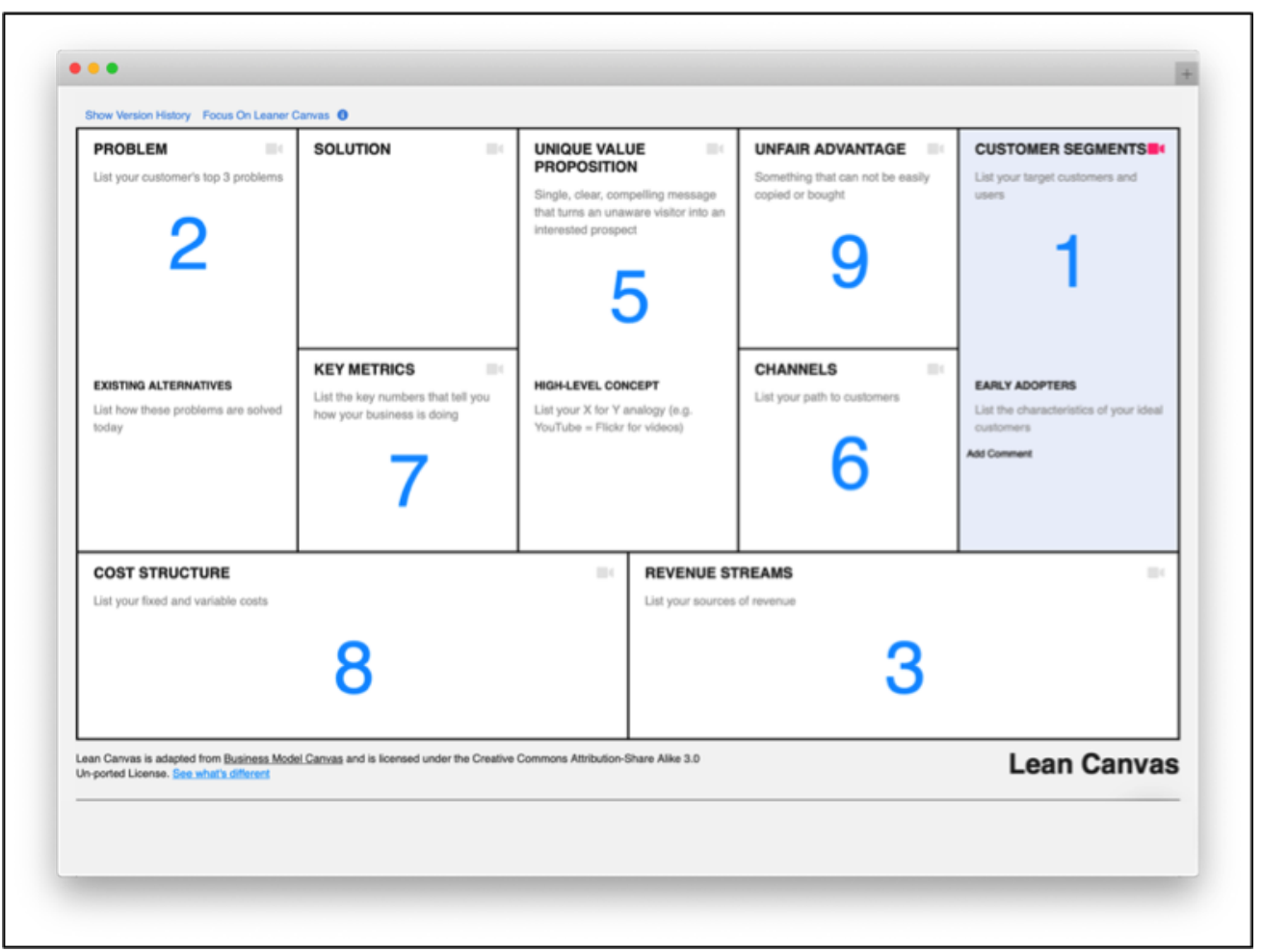

Figura 3.5: Lean Canvas

Fonte:www. leanstack.com

\subsection{2}

\section{Product/Market Fit Canvas}

O Product/Market FIT Canvas (PMF Canvas) foi co-criado por um grupo de mais de 150 pessoas do mundo todo. Ele tem uma aplicação mercadológica, onde se busca identificar nichos de mercado com potencial para serem atendidos, em casos onde os atuais players não o fazem de forma satisfatória.

O PMF Canvas é dividido em dois conjuntos de blocos com propósitos distintos. O primeiro destes blocos busca definir o produto / serviço, trazendo perguntas norteadoras para auxiliar no entendimento dos seguintes pontos: 
- Quais alternativas existem no mercado que podem ser comparadas ao produto/serviço proposto?

- Quais são as principais funcionalidades do produto/serviço propostas?

- Qual a sua proposta de valor?

- Quais métricas balizarão o sucesso da inovação?

No segundo bloco, os estímulos visam identificar os segmentos de clientes e a forma de atendê-los, tendo as seguintes perguntas norteadoras:

- Quais são as características dos usuários e as tarefas que estes buscam fazer?

- Qual é a experiência do usuário?

- Quais são os seus problemas e necessidades?

- Qual será o canal de distribuição do produto/serviço?

O PMF Canvas é indicado para o desenho de aplicativos, sendo uma ferramenta que possibilita analisar o aplicativo no estágio de lançamento. Através do PMF Canvas se consegue estabelecer o Minimum Viable Product - MVP, ou seja, os requisitos mínimos que um produto necessita para ser colocado em teste junto ao usuário.

A Figura 3.6 ilustra o PMF Canvas em seu formato atual.

\subsection{3}

\section{Project Model Canvas}

O Project Model Canvas [13] foi criado em 2013 no Brasil e teve como referência o BMC de Osterwalder. Seu autor é José Finocchio Junior, um consultor com certificação em gerenciamento de projetos pelo PMI (Project Management Institute), uma instituição internacional, sem fins lucrativos, com mais de 650.000 associados, entre eles profissionais que atuam em gestão de projetos em 185 países.

O Project Model Canvas, ilustrado na Figura 3.7, está divido em 13 blocos, integrados com a teoria e a prática das necessidades do gerenciamento de projetos pelos critérios do PMI. As duas colunas a esquerda do Project Model Canvas são endereçadas ao Gerente de Projeto (GP), e buscam responder questões associadas a justificativa do projeto, a seu objetivo e aos seus benefícios. O principal foco é definir o porquê do desenvolvimento do projeto. Os campos Produto e Requisitos, buscam responder o quê pretende-se construir.

A partir destes campos da esquerda do CANVAS, são apresentados os Steakholders e a Equipe de desenvolvimento, definindo respectivamente a quem 


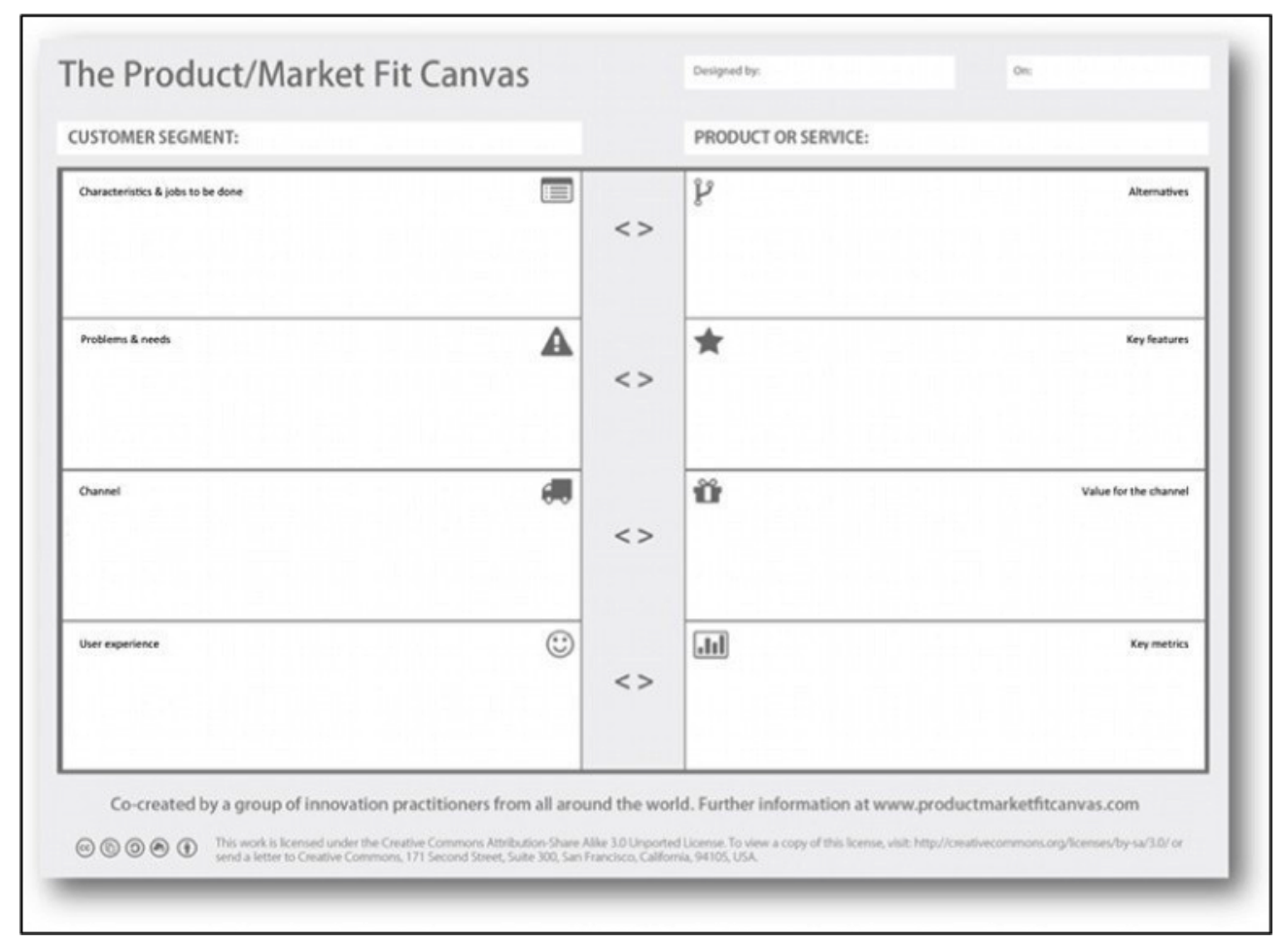

Figura 3.6: PMF Canvas

Fonte:www.creatlr.com

interessa o projeto e quem participa do mesmo. Os campos Premissas, Grupo de entregas e Restrições definem como o resultado do projeto ocorrerá, se em forma de produto ou de serviço. Os campos Riscos, Linha do tempo e Custos finalizam informações de sobre e quando e, consequentemente quanto será necessário para que o projeto ocorra.

\subsection{4}

\section{Marketing Strategy Canvas}

O Marketing Strategy Canvas é um CANVAS específico para a criação compartilhada de um planejamento de marketing, simplificando a elaboração de estratégias e reduzindo a necessidade de elaboração de longos documentos. Não se trata de um substituto ao plano de marketing, porém contribui para a facilitação da comunicação entre os envolvidos no processo.

O CANVAS ilustrado na Figura 3.8 está dividido em 14 campos autoexplicativos, é de livre uso, sendo necessário apenas a citação do autor Daniel Rodrigo Bastreghi. 


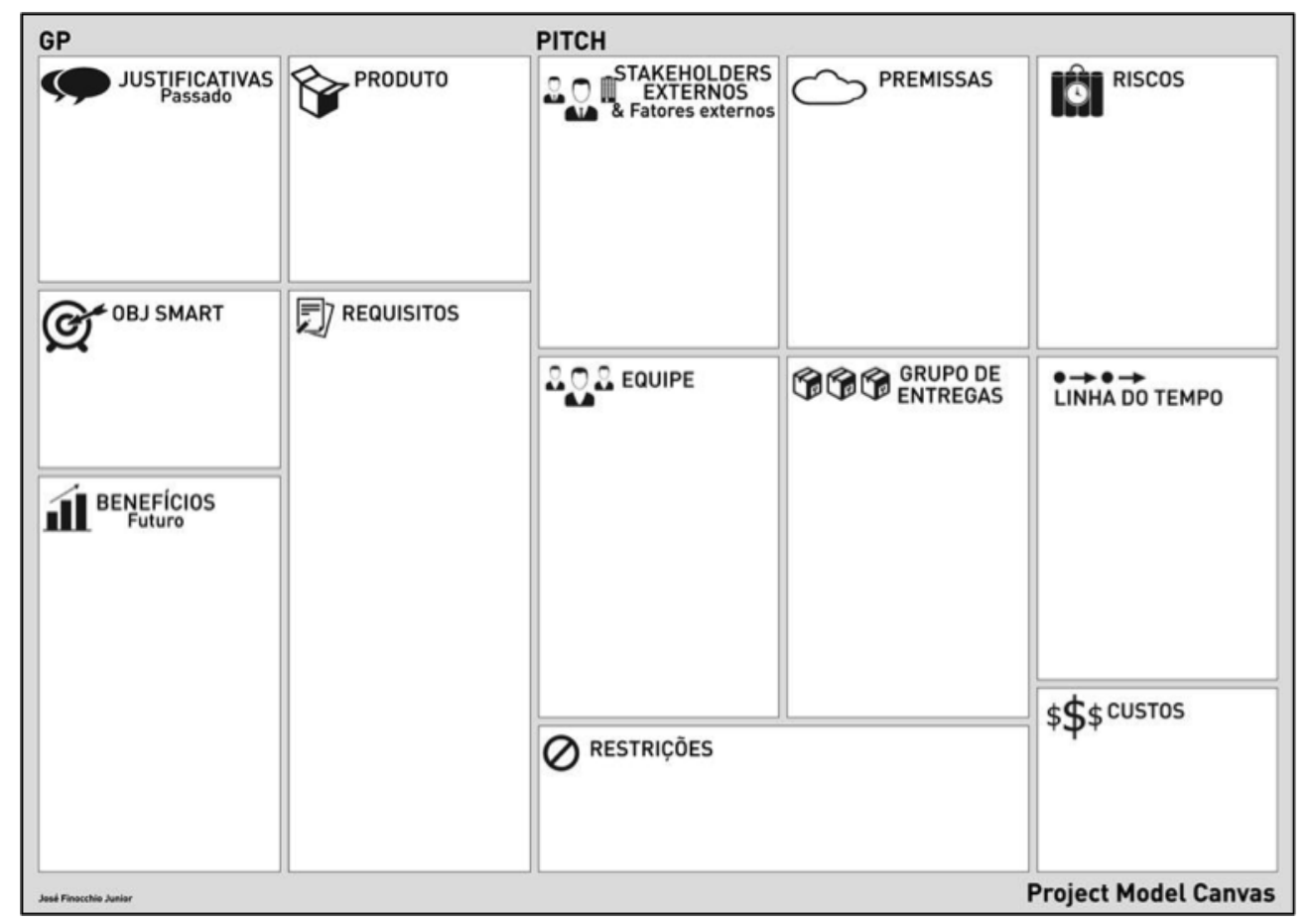

Figura 3.7: PM Canvas

Fonte:www.pmcanvas. com.br

\subsection{5}

\section{Marketing Campaign Model Canvas}

O Marketing Campaign Model Canvas (MC2) é uma ferramenta também específica para o segmento de marketing, sendo que o seu foco é o desenvolvimento da campanha de marketing/comunicação para um fim específico. Os campos também são autoexplicativos. O material foi criado pela Get It, uma consultoria de marketing com atuação em Singapura, Índia e Malásia.

A Figura 3.9 apresenta o Marketing Campaign Model Canvas em seu formato atual.

\subsection{6}

\section{Customer Journey Canvas}

O Customer Journey Canvas trata da jornada do usuário em forma de CANVAS, apresentado na publicação Design a Better Business [14], cujos autores são membros da BMI (Business Model Inc.). A BMI é uma consultoria com foco em design estratégico com escritórios em Amsterdam, Nova Iorque, Sydney, Brisbane e Taipé. Alguns dos autores do Customer Journey Canvas também foram co-criadores do BMC de Osterwalder.

A proposta deste CANVAS é ser uma ferramenta para geração de insigths ao avaliar o mapeamento da experiência do usuário. Junto ao Customer 


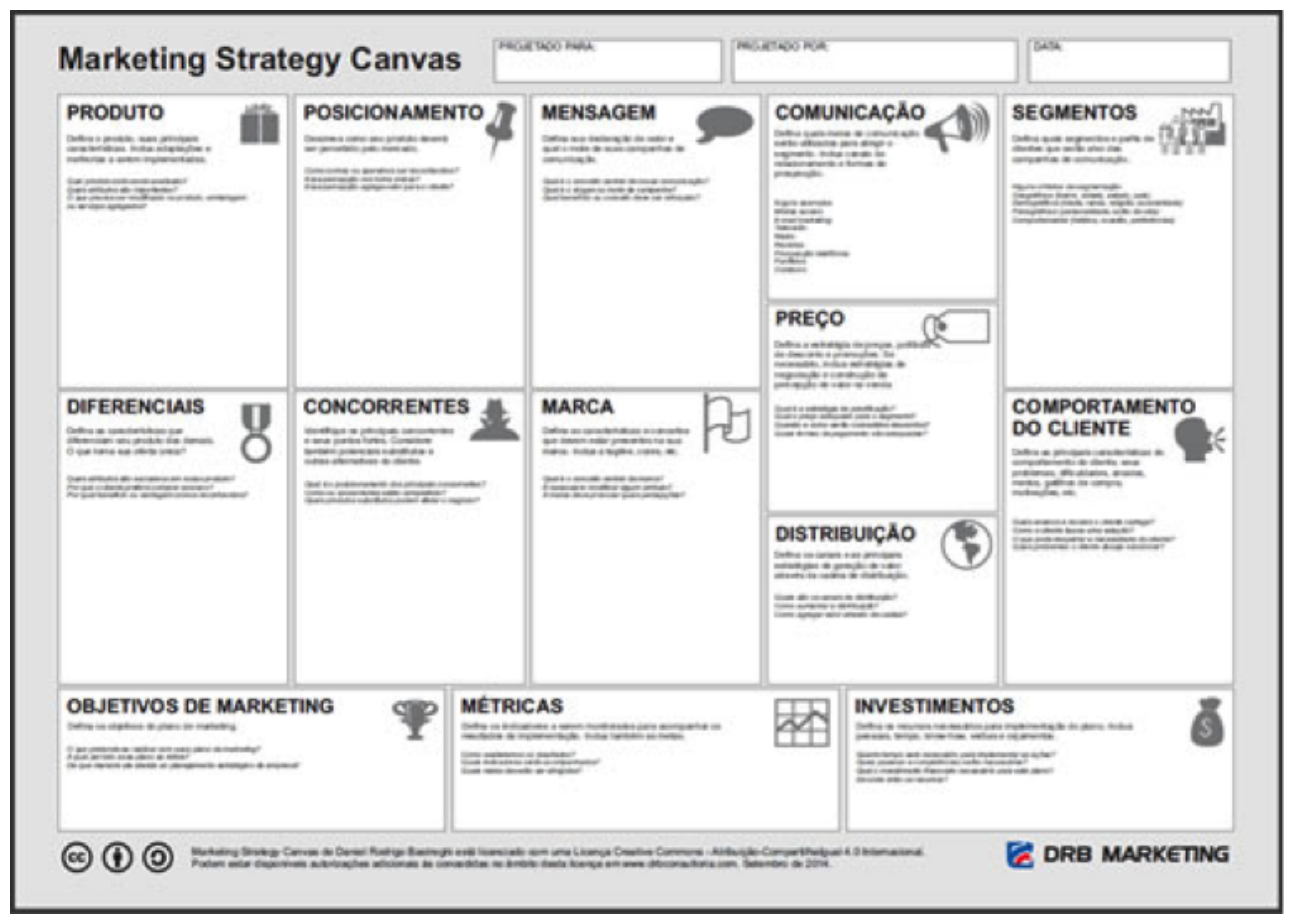

Figura 3.8: MS Canvas

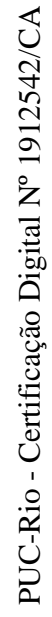

Fonte:www.drbmarketing. com . br

Journey Canvas, também são citados outros 17 CANVAS que auxiliam nas dinâmicas de ideação em grupo, que seguem abaixo listados:

1. Value Proposition Canvas;

2. Persona Canvas;

3. 5 Bold Steps Vision Canvas;

4. Prototype Canvas;

5. Storytelling Canvas;

6. Experiment Canvas;

7. Design Criteria Canvas;

8. Cover Story Vision Canvas;

9. Context Canvas;

10. Team Charter Canvas;

11. Validation Canvas;

12. Riskiest Assumption Canvas; 


\section{MARKETING CAMPAIGN MODEL CANVAS}

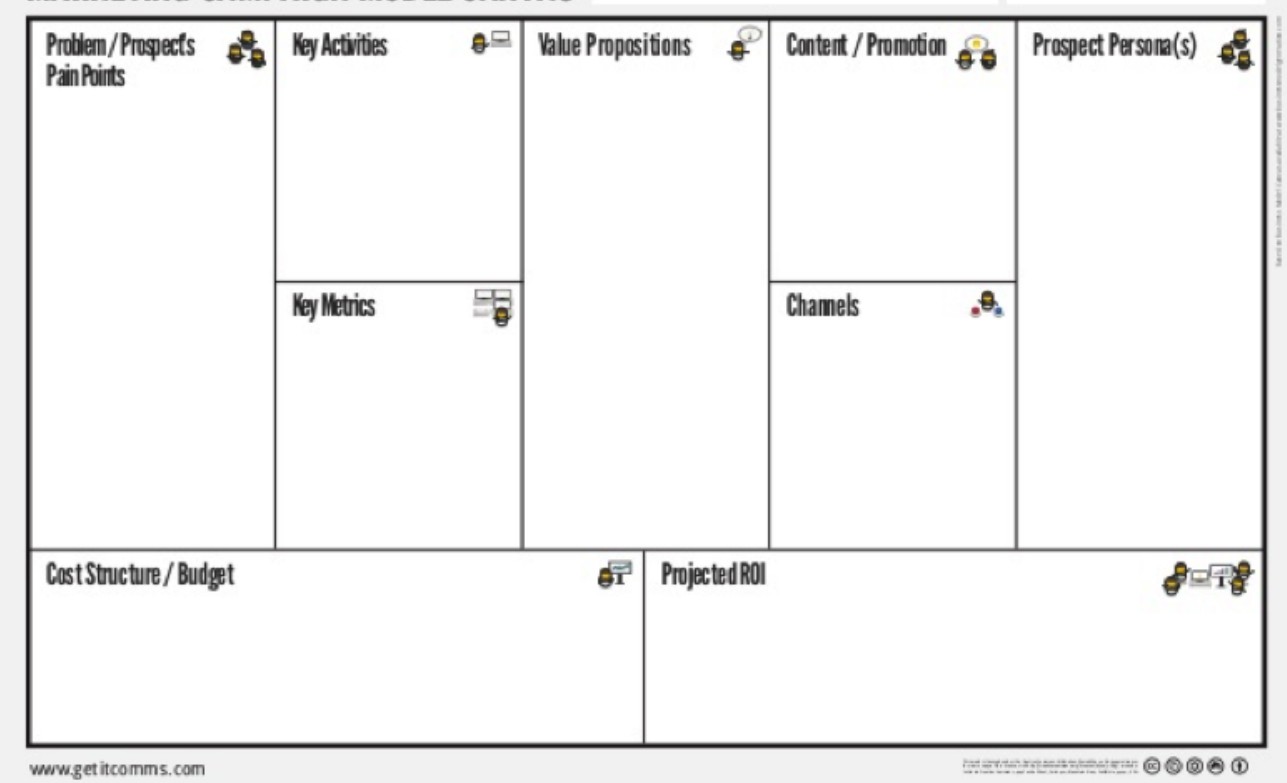

Figura 3.9: MC2 Canvas

Fonte:www.getitcomms.com

13. Innovation Matrix Canvas;

14. War Room Checklist;

15. Wall of Ideas;

16. Creative Matrix;

17. Investment Readiness Level.

Todo o material sobre o Customer Journey Design está disponível online, cujo site ${ }^{1}$ informa já terem ocorrido mais de 50.000 downloads de conteúdo deste CANVAS. A Figura 3.10 ilustra o Customer Journey Design.

Uma outra versão de um CANVAS para jornada do usuário, ilustrado na Figura 3.11, com o mesmo nome e finalidade também pode ser encontrado na plataforma Canvanizer ${ }^{2}$, que divide a experiência do usuário em três momentos: Pré-período do serviço, Período do serviço e Pós-período do serviço.

\footnotetext{
${ }^{1}$ www.designabetterbusiness.tools

2 www.canvanizer.com
} 


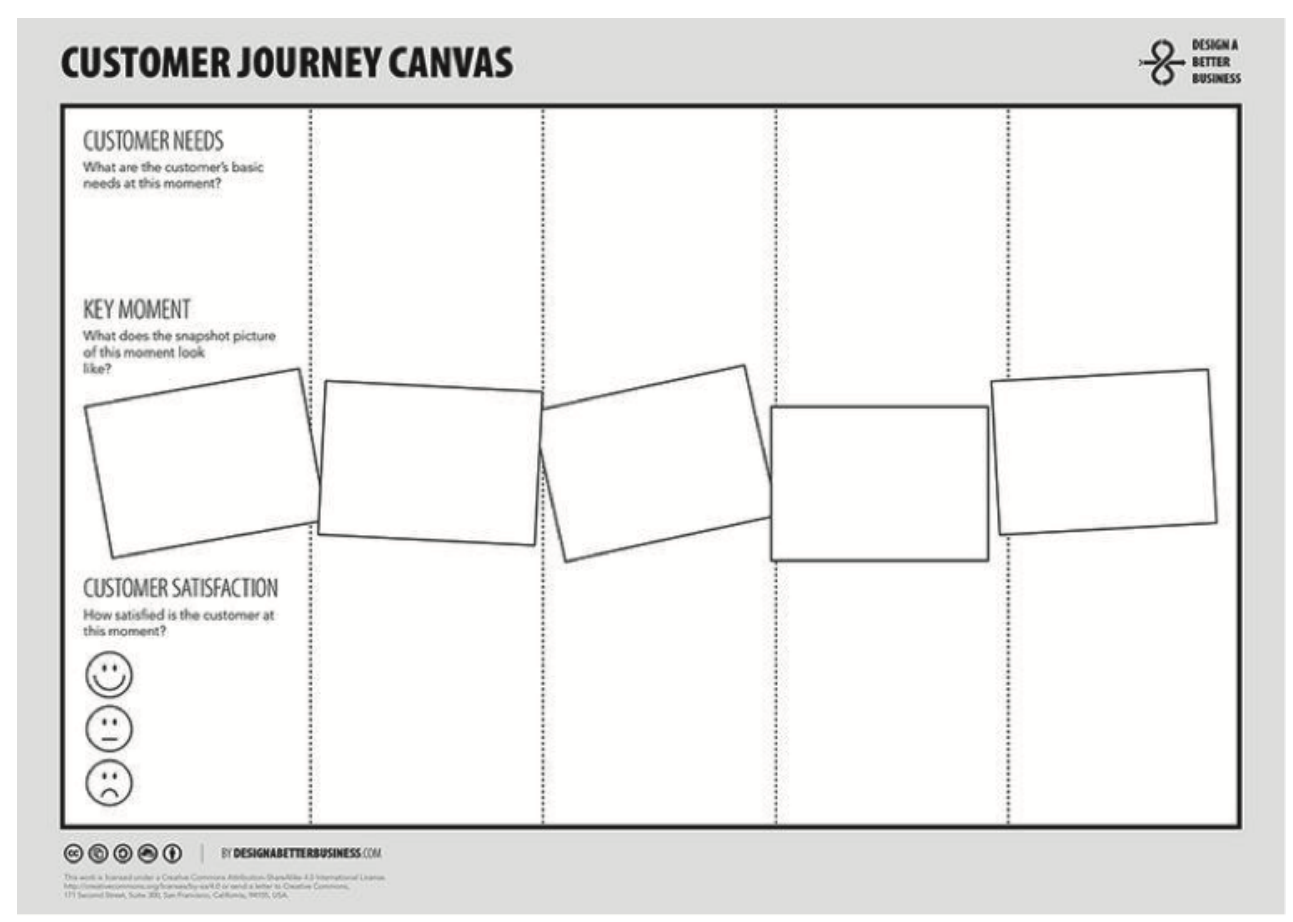

Figura 3.10: CJ Canvas

Fonte:www.designabetterbusiness.tools

\subsection{7}

\section{Business Model You}

A construção deste CANVAS foi uma iniciativa de Tim Clark, que junto aos autores do Business Model Generation [9], buscou transformar o BMC em um CANVAS pessoal, para o desenvolvimento de carreira. A iniciativa reuniu 328 profissionais espalhados por 43 países, que foram co-criadores do livro [15] publicado em 2012.

Este CANVAS, conforme ilustrado na Figura 3.12, possui nove campos, assim como o BMC, que são convertidos para questões do campo pessoal. Os nove campos são os seguintes, com as suas devidas perguntas norteadoras:

1. Recursos Principais

- Quem é você?

- $\mathrm{O}$ que você possui?

2. Atividades-Chave

- O que você faz?

3. Clientes

- Quem você ajuda? 


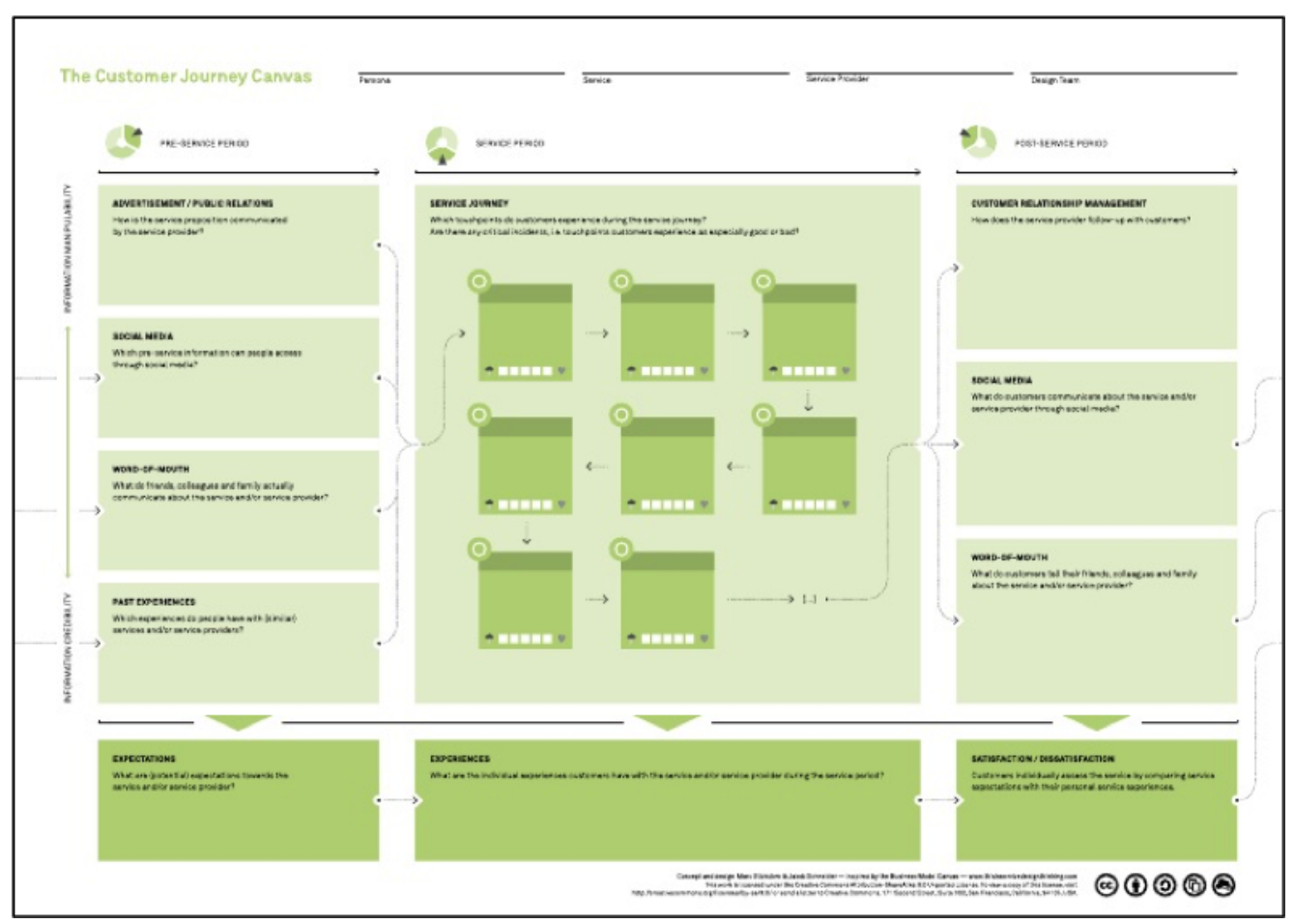

Figura 3.11: CJ Canvas

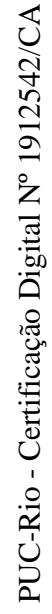

Fonte:www. canvanizer.com

4. Proposta de Valor

- Como você os ajuda?

5. Canais

- Como chegam até você?

- Como você entrega?

6. Relacionamento com clientes

- Como vocês interagem?

7. Parcerias principais

- Quem ajuda você?

8. Fontes de receita e benefícios

- O que você ganha?

9. Estrutura de custo

- O que você oferece? 


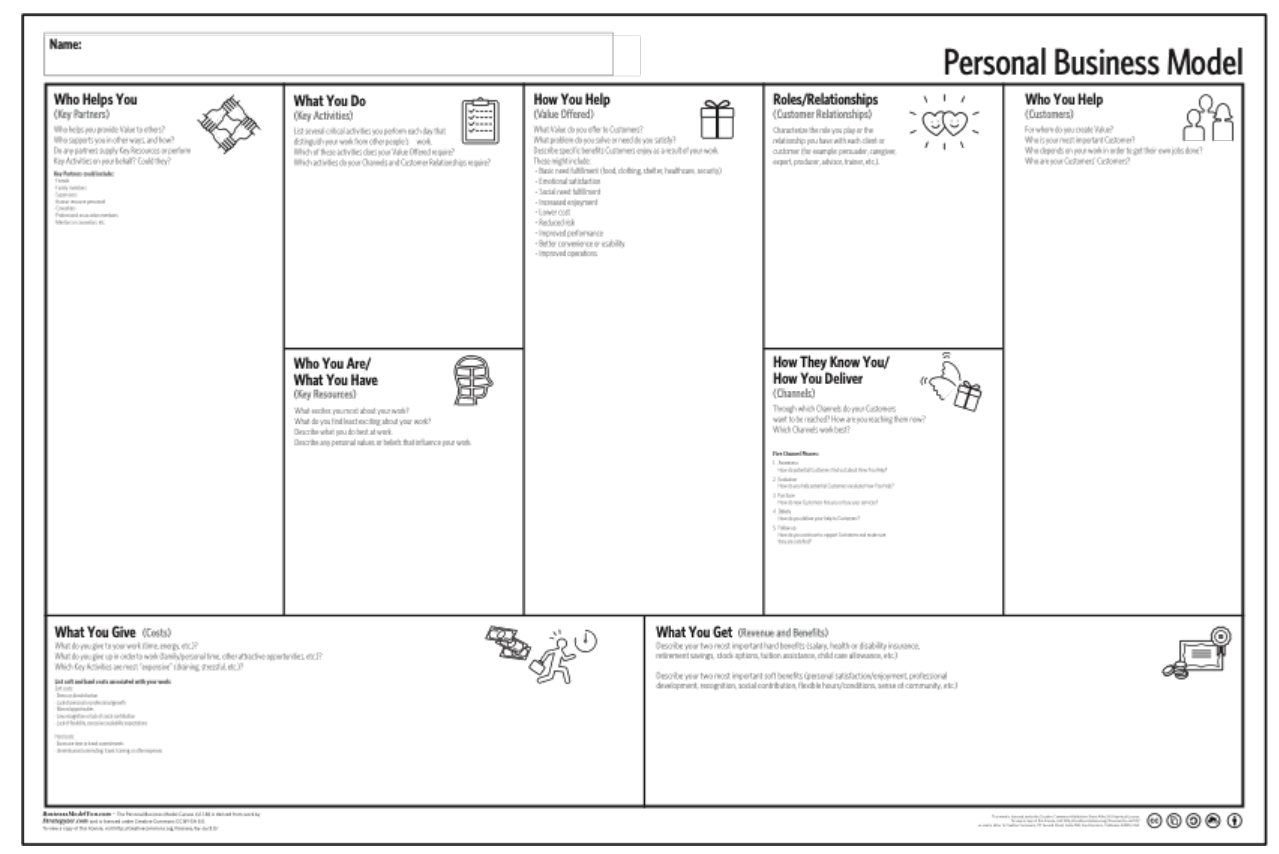

Figura 3.12: Business Model You

Fonte:www . businessmodelyou.com

\subsection{8}

\section{Corporate Innovation Canvas}

O CANVAS Corporate Innovation Canvas foi idealizado por Alexander Cowan, um professor da Universidade de Virgínia (Darden School Business). Segundo o autor, este CANVAS foi testado em empresas com valor de mercado superior a US\$ 1 bilhão que desejavam incubar um portfolio de inovações como parte de seu plano de crescimento de curto e longo prazos.

O Corporate Innovation Canvas, ilustrado na Figura 3.13 torna evidente os objetivos estratégicos da empresa para a equipe envolvida em projetos de inovação, conferindo autonomia e direcionamento às suas decisões.

O CANVAS é dividido em 9 campos, com perguntas norteadoras, conforme listados abaixo:

1. Segmentos de clientes

- Quem são os seus clientes?

- O que eles estão pensando?

2. Cenários de problemas

- Quais trabalhos, necessidades, desejos são importantes para seus clientes?

3. Disruptores / Catalisadores 


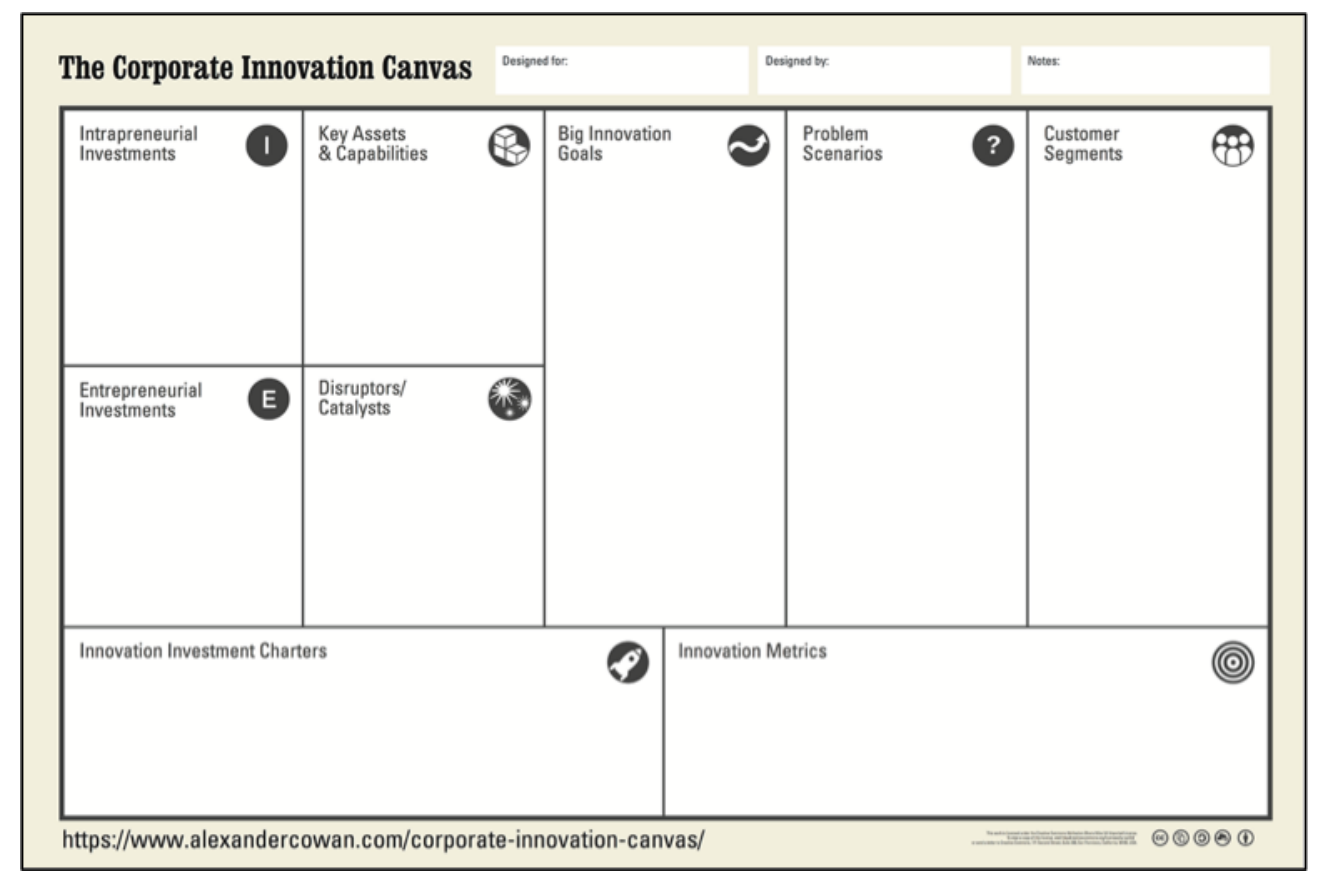

Figura 3.13: Corporate Innovation Canvas

Fonte:www . alexandercowan.com

- O que está mudando o cenário do setor e / ou alternativas atendem as necessidades de seus clientes?

4. Grandes objetivos de inovação

- Quais inovações melhorariam a sua empresa?

- Como isto varia no curto e longo prazo?

5. Intenções com o investimento em inovação

- Como a empresa investirá em inovação e com quais cronogramas e critérios de sucesso?

6. Métricas de inovação

- Quais são métricas corretas para a sua inovação?

7. Investimentos intraempreendedores

- Que investimentos internos a empresa fará para promover a inovação no curto e longo prazo?

8. Investimentos empresariais

- Que investimentos externos a empresa fará para promover a inovação no curto e longo prazo? 
9. Principais ativos e capacidades

- O que a empresa tem agora que pode contribuir significativamente para a inovação futura?

O Corporate Innovation Canvas não direciona o que criar, pois, segundo o autor, a inovação não funciona de forma imediata e trata de um processo de exploração do desconhecido e do incerto. Entretanto, a ferramenta auxilia nesse processo, trazendo um foco e uma disciplina de apoio.

\subsection{9}

\section{T\&D Canvas}

O CANVAS T\&D Canvas [16] apresentado na Figura 3.14, é direcionado à gestão de pessoas, ligado às ações de treinamento e desenvolvimento de alta complexidade de administração pelos gestores de RH de uma empresa. O autor desta ferramenta é Marcelo de Elias, professor da FGV e da Fundação Don Cabral, e fundador da Universidade da Mudança, um portal que apresenta conteúdos sobre negócios, vida e carreira dentre outros.

Este CANVAS é direcionado a profissionais de $\mathrm{RH}$, que buscam desenvolver projetos de educação corporativa. A estrutura do CANVAS é simples, apresentando três blocos com objetivos específicos. O primeiro bloco é dedicado a identificação dos problemas, tendo como estímulo as causas reais, para em seguida, identificar e relacionar os efeitos e as consequências observadas.

O segundo bloco do CANVAS busca dar forma ao programa de treinamento, descrevendo o objetivo a ser perseguido e as ações propostas, respondendo as questões: o que, onde, como, quando, quem e quanto custa.

O terceiro e último bloco está formatado para a pós execução, onde se descreve como os resultados serão aferidos, os resultados alcançados e ações corretivas para futuras oportunidades. O T\&D é um CANVAS que acompanha o projeto em todas as etapas de sua existência.

\section{3}

\section{Os CANVAS e suas Aplicações}

Podemos observar que os CANVAS são utilizados como ferramentas para atender a diversas finalidades, começando pelo BMC (Business Model Canvas) para a modelagem de todo e qualquer negócio, até o BMY (Business Model You) que se destina a modelagem da carreira de um indivíduo.

A tabela 3.1 traz um sumário dos CANVAS apresentados nesse trabalho, identificando seus autores e suas áreas de aplicação. 


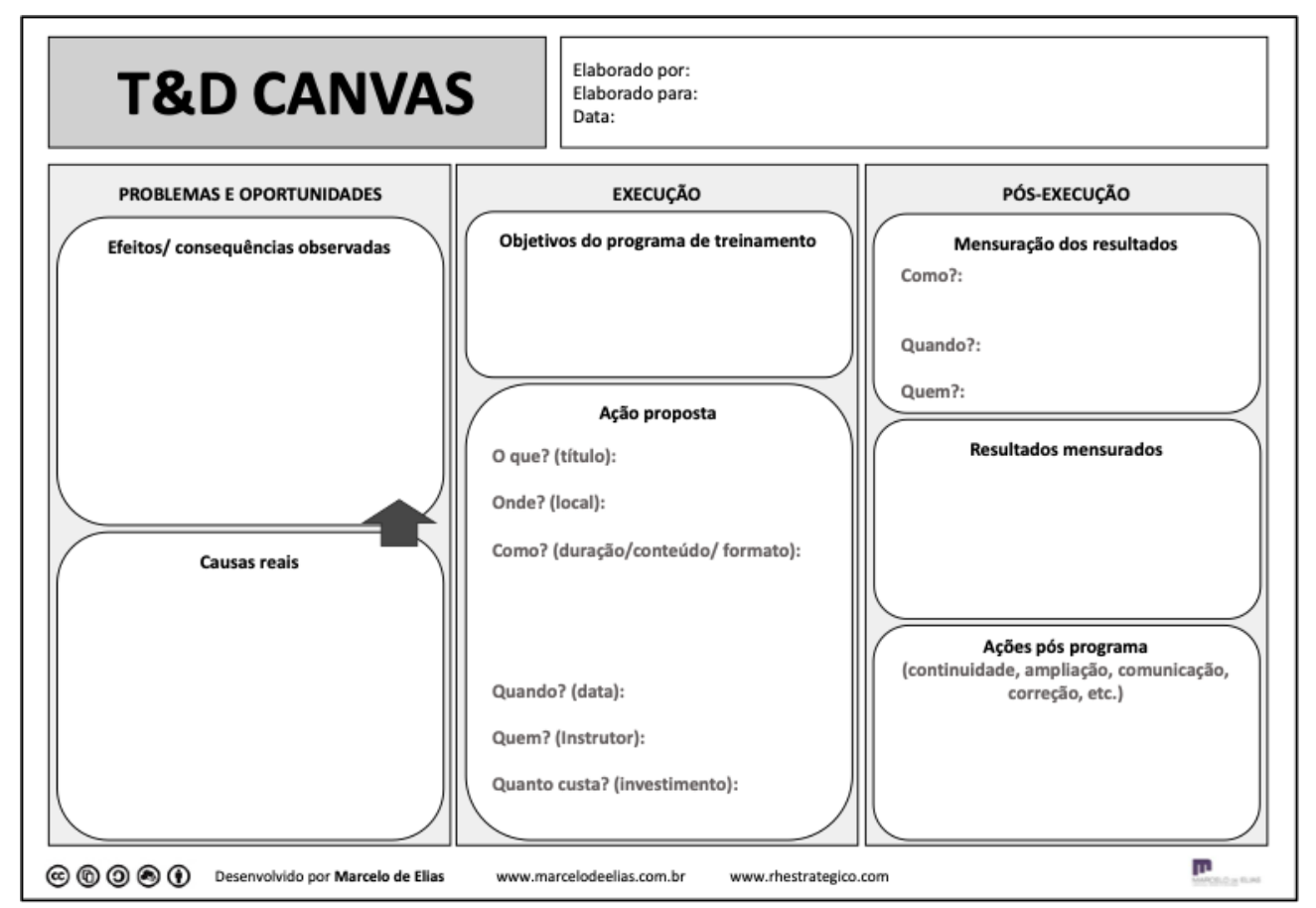

Figura 3.14: T\&D Canvas

Fonte:www.marcelodeelias.com.br

Os CANVAS vêm se destacando por proporcionarem processos de desenvolvimento do pensamento na estruturação de algo, por exemplo um produto ou um serviço, trazendo reflexões através de perguntas norteadoras que ajudam a compreender a complexidade daquilo que se pretende construir, quer num negócio ou na vida pessoal. No capítulo seguinte, a experiência de designers e não designers, que atuam com Design de Serviço, trará múltiplas visões de quem se utiliza dos CANVAS para atingir os seus objetivos projetuais. 
Tabela 3.1: Sumário dos CANVAS Apresentados (Fonte: o autor)

\begin{tabular}{|c|c|c|}
\hline $\begin{array}{c}\text { NOME DO } \\
\text { CANVAS }\end{array}$ & AUTOR & APLICAÇÃO \\
\hline $\begin{array}{l}\text { BUSINESS } \\
\text { MODEL } \\
\text { CANVAS }\end{array}$ & $\begin{array}{c}\text { Alexander } \\
\text { Osterwalder e } \\
\text { Ives Pigneur }\end{array}$ & $\begin{array}{c}\text { Modelagem de } \\
\text { negócios em geral }\end{array}$ \\
\hline LEAN CANVAS & Ash Maurya & $\begin{array}{l}\text { Modelagem de } \\
\text { negócios para } \\
\text { startups }\end{array}$ \\
\hline $\begin{array}{c}\text { PRODUCT / } \\
\text { MARKET FIT } \\
\text { CANVAS }\end{array}$ & Criação Coletiva & $\begin{array}{l}\text { Desenvolvimento } \\
\text { de aplicativos }\end{array}$ \\
\hline $\begin{array}{c}\text { PROJECT } \\
\text { MODEL } \\
\text { CANVAS }\end{array}$ & José Finnocchio & $\begin{array}{c}\text { Gestão de } \\
\text { projetos pelo PMI }\end{array}$ \\
\hline $\begin{array}{l}\text { MARKETING } \\
\text { STRATEGY } \\
\text { CANVAS }\end{array}$ & $\begin{array}{c}\text { Daniel Rodrigo } \\
\text { Bastreghi }\end{array}$ & $\begin{array}{l}\text { Planejamento de } \\
\text { Marketing }\end{array}$ \\
\hline $\begin{array}{c}\text { MARKETING } \\
\text { CAMPAIGN } \\
\text { MODEL } \\
\text { CANVAS }\end{array}$ & Get It & $\begin{array}{l}\text { Gerenciamento de } \\
\text { marke- } \\
\text { ting/Comunicação }\end{array}$ \\
\hline $\begin{array}{l}\text { CUSTOMER } \\
\text { JOURNEY } \\
\text { CANVAS }(\mathrm{A})\end{array}$ & $\begin{array}{l}\text { Design Better } \\
\text { Business }\end{array}$ & $\begin{array}{l}\text { Mapeamento de } \\
\text { comportamento } \\
\text { de usuário }\end{array}$ \\
\hline $\begin{array}{l}\text { CUSTOMER } \\
\text { JOURNEY } \\
\text { CANVAS (B) }\end{array}$ & Canvanizer & $\begin{array}{l}\text { Mapeamento de } \\
\text { comportamento } \\
\text { de usuário }\end{array}$ \\
\hline $\begin{array}{c}\text { BUSINESS } \\
\text { MODEL YOU }\end{array}$ & Tim Clark & $\begin{array}{c}\text { Plano ou } \\
\text { reposicionamento } \\
\text { de carreira }\end{array}$ \\
\hline $\begin{array}{c}\text { CORPORATE } \\
\text { INOOVATION } \\
\text { CANVAS }\end{array}$ & Alexander Cowan & $\begin{array}{c}\text { Gestão de } \\
\text { inovação } \\
\text { corporativa }\end{array}$ \\
\hline T\&D CANVAS & Marcelo Elias & $\begin{array}{c}\text { Gestão de RH } \\
\text { para treinamento } \\
\text { de pessoal }\end{array}$ \\
\hline
\end{tabular}




\section{4}

\section{As Experiências com os CANVAS}

A variedade de CANVAS criados a partir do BMC, revela que a ferramenta pode ser aplicada em diversos segmentos de mercado. Sua aplicação ganha vários formatos, proporcionando melhor entendimento e tornando visível as áreas de atenção necessárias para que um negócio seja sustentável e viável, do momento de sua concepção até sua implementação. Desta forma, as ferramentas CANVAS servem como objeto de concentração dos esforços de profissionais de diversas áreas, como engenheiros, economistas, administradores, profissionais de recursos humanos, profissionais de TI, assim como para os designers.

Diante da variedade de CANVAS, fez-se necessário investigar a experiência que os profissionais que trabalham com Design de Serviços possuem com a utilização dos CANVAS. Esta investigação foi dividida em dois momentos, com propósitos distintos como apresentado a seguir.

\section{1}

\section{O primeiro momento da investigação}

A proliferação dos CANVAS que foi abordado no Capítulo 3 desta dissertação apontou a necessidade de identificar questões, tais como, quais são os CANVAS mais conhecidos, os mais utilizados, as dificuldades e os benefícios de sua utilização. Além destes pontos de interesse primário, a investigação buscou descobrir o perfil do profissional com o qual o designer interage, os motivos pelos quais estes escolhem um CANVAS para utilizar em seus projetos, os campos dos CANVAS com maior dificuldade de manuseio, dentre outras questões sobre a percepção destes profissionais quanto a utilização das ferramentas CANVAS em seus projetos de Design de Serviço.

O método quantitativo foi adotado para identificar a concentração de respostas nas questões anteriormente citadas. O tamanho da amostragem foi definido tomando por base a população de 588 profissionais que trabalham com Design de Serviço, de acordo com o Diagnóstico de Design Brasileiro 2014, realizado pelo Centro Brasil Design ${ }^{1}$, uma entidade sem fins lucrativos que inspira, informa e conecta as partes interessadas por meio de projetos e

${ }^{1}$ O Centro Brasil Design (https://www.cbd.org.br) 
programas que impactam positivamente os negócios, se utilizando do design e inovação como driver estratégico para a competitividade.

Durante os meses de julho a agosto de 2019, um formulário online ${ }^{2}$ com 24 perguntas teve 57 respondentes válidos, atribuindo uma margem de erro de 10,33\% à pesquisa realizada. Para o perfil do conteúdo investigado, esta margem de erro é confortável, considerando que a população amostral de profissionais que atuam com Design de Serviço é de 508 postos de trabalho. A Figura 4.1 apresenta a concentração de profissionais por segmentação de atuação em Design no território nacional.

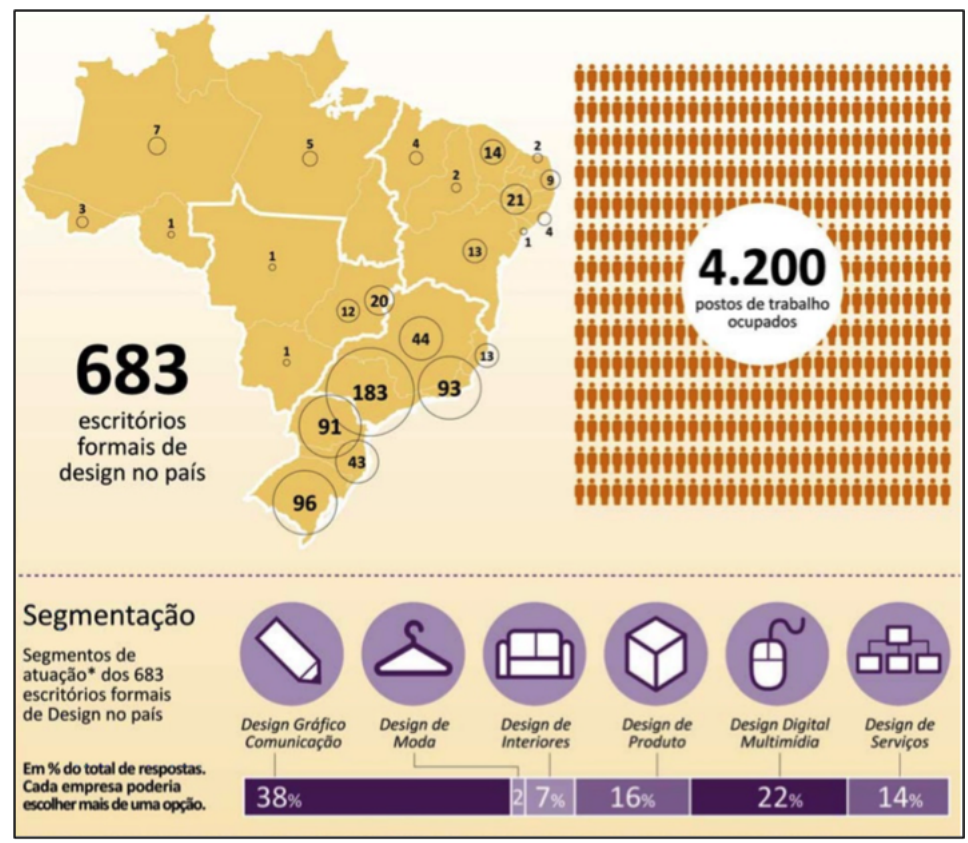

Figura 4.1: Concentração de profissionais por segmento de atuação. Fonte: Diagnóstico do Design Brasileiro 2014.

Como critério de seleção para validação das respostas, os respondentes deveriam manifestar já terem trabalhado com Design de Serviço no Brasil, nos estados do Rio de Janeiro e São Paulo, estados de maior concentração de profissionais com atuação neste segmento. O grupo amostral caracterizou-se por possuir majoritariamente qualificação de pós-graduação, formação em design, engenharia, comunicação além de outras áreas e com alta representatividade de profissionais com mais de seis anos de experiência, de acordo com as tabelas abaixo $4.1,4.2$ e 4.3 .

O estudo observou que os CANVAS declarados pelos respondentes como os mais utilizados foram o Business Model Canvas (91,43\%), Customer Journey Canvas (45,71\%), Lean Canvas $(31,43 \%)$, mostrando que os respondentes

${ }^{2} \mathrm{O}$ formulário online pode ser acessada no link https://my.survio.com/ A6W5V2V9F9Y9P5H2E2B7/designer. 
Tabela 4.1: Nível de formação dos respondentes (Fonte: o autor)

\begin{tabular}{|c|c|}
\hline Nível de Formação & Percentual \\
\hline Mestrado / Doutorado & $33 \%$ \\
\hline Pós-graduação & $30 \%$ \\
\hline Graduação completo & $28 \%$ \\
\hline Graduação incompleto & $7 \%$ \\
\hline Outra formação & $2 \%$ \\
\hline
\end{tabular}

Tabela 4.2: Graduação dos respondentes (Fonte: o autor)

\begin{tabular}{|c|c|}
\hline Curso & Percentual \\
\hline Design & $60 \%$ \\
\hline Comunicação & $16 \%$ \\
\hline Administração & $2 \%$ \\
\hline Engenharia & $5 \%$ \\
\hline Informática & $7 \%$ \\
\hline Outros & $10 \%$ \\
\hline
\end{tabular}

Tabela 4.3: Tempo de formação dos respondentes (Fonte: o autor)

\begin{tabular}{|c|c|}
\hline $\begin{array}{c}\text { Há quanto tempo se } \\
\text { graduou }\end{array}$ & Percentual \\
\hline Entre 0 e 2 anos & $21 \%$ \\
\hline Entre 2 a 4 anos & $11 \%$ \\
\hline Entre 4 e 6 anos & $7 \%$ \\
\hline Mais de 6 anos & $61 \%$ \\
\hline
\end{tabular}

utilizam mais de um CANVAS em projetos de Design de Serviços (índice multiplicidade das respostas 2,43). Este resultado nos faz considerar a necessidade que, apesar da grande quantidade de CANVAS listados no Capítulo 3 desta dissertação, designers, que pretendam trabalhar com Design de Serviço, terem em sua formação acadêmica habilidades no Business Model Canvas, além de mais outros dois tipos de CANVAS, que podem variar de acordo com o segmento que busquem atuar profissionalmente.

Da listagem dos CANVAS apresentados, foi unânime o conhecimento do Business Model Canvas, tornando-se indispensável que designers tenham habilidade no seu uso, compreendendo o seu funcionamento, para que a prática do Design de Serviço seja estratégica, trazendo reflexões e desconstruindo silos de conhecimento para criar algo que encontre a convergência que o trabalho com equipes multidisciplinares tem como um dos desafios.

Quanto à preferência de uso, o Business Model Canvas foi o mais citado $(57,14 \%)$, seguido por Customer Journey Canvas (20\%) e Lean Canvas 
(14,29\%). A preferência pela utilização de um CANVAS está associada a adaptação que ferramenta possibilita aos diversos segmentos nos quais os entrevistados atuam. Outro aspecto determinante pela escolha é o fato do BMC ser o mais conhecido pelos profissionais que participam dos processos onde os CANVAS são utilizados, tornando mais fácil o entendimento da ferramenta em sua prática. Entretanto, o baixo percentual de respostas relativo à percepção de que a escolha de CANVAS está ligada ao fato de ser "mais amistoso para trabalhar", sugere que a ferramenta é complexa no entendimento de sua utilização por parte dos usuários.

As áreas mais citadas dos projetos de Design de Serviço onde os CANVAS são utilizados foram Inovação/Tecnologia e Educação/Treinamento, mostrando um potencial de atuação para designers, na região onde a pesquisa foi realizada, no segmento de formação de mão de obra com o uso de tecnologia empregada na interface com o usuário.

Pela fato da visão holística ser exigida para o bom manejo das ferramentas CANVAS, a percepção de necessidade de formação complementar para um melhor uso da ferramenta se torna mais evidente no grupo de respondentes designers comparados aos não designers, tendo concentração de dificuldades nas habilidades ligadas às áreas de Finanças, Matemática e Marketing como, por exemplo, Retorno do Investimento, Métricas e Fontes de Recursos. A Figura 4.2 ilustra as áreas de dificuldades para os respondentes designers.

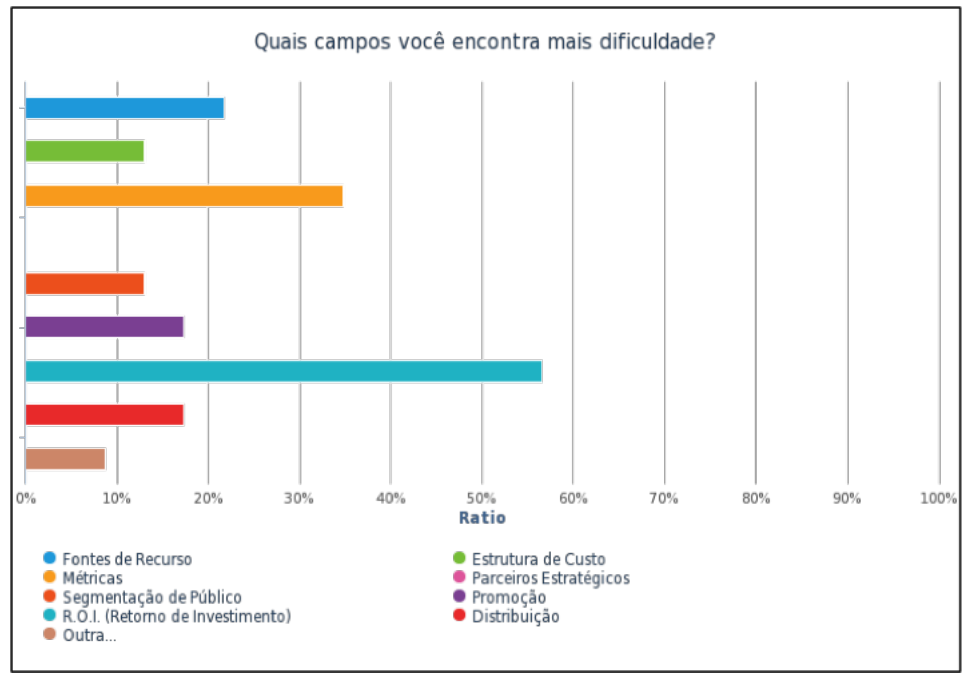

Figura 4.2: Campos de dificuldades nos CANVAS para designers. Fonte:o autor

Quanto a divergências nas respostas dos perfis de respondentes designers e não designers, tornou-se evidente (67\% dos respondentes) que os designers manifestaram não possuir formação suficiente para trabalhar todos os campos 
do conhecimento que as ferramentas CANVAS apresentam comparados aos não designers, uma vez que $44 \%$ dos respondentes manifestaram este mesmo comportamento.

Um outro aspecto denota divergência nestes dois perfis profissionais. Quando submetidos a opções de respostas, previamente listadas, sobre para qual finalidade o CANVAS é considerado bom, o grupo de não designers concentrou as suas respostas (78\%) na opção "ampliar o campo de visão quando estou desenvolvendo um projeto", enquanto os designers deram as respostas divididas por três opções: "simplificar o entendimento das questões envolvidas no projeto" (38\%), "ampliar o campo de visão quando estou desenvolvendo um projeto" (33\%) e "alinhar a equipe aos objetivos do projeto" (28\%).

Esta diferença no perfil de respostas pode nos apresentar algumas possibilidades de interpretação. Uma delas é que designers, possivelmente, por receberem estímulos em sua formação quanto ao entendimento do contexto no qual o projeto está inserido, já possuem em seu processo de trabalho uma visão ampliada das questões a serem tratadas na construção de uma solução. O entendimento da complexidade dos problemas de projeto, a empatia para compreender as questões do usuário e a habilidade de observar o problema, não de forma isolada, mas dentro de um contexto, podem estar contribuindo para que os designers já possuam uma visão ampliada sobre os campos do desenvolvimento de um projeto.

Por outro lado, os CANVAS, em especial do Business Model Canvas, e os que tratam sobre modelagem de negócios, servem como um guia que aponta a necessidade de relação entre as áreas operativas de um negócio que devem ser consideradas durante a proposição de algo. De uma forma geral, os CANVAS para modelagem de negócios são ferramentas visuais que facilitam o entendimento das engrenagens de negócio, organizando os pré-requisitos operativos por áreas, para evidenciar o que deve ser considerado para que uma solução seja sustentável quando for implementada. Esta facilitação como ferramenta visual que os CANVAS oferecem, possibilita conduzir o diálogo intragrupal, direcionando a atenção entre as partes interessadas e as envolvidas no desenvolvimento de um projeto.

A diversidade de saberes dos integrantes do grupo de trabalho pode tornar as dinâmicas, onde os CANVAS são empregados, em ambientes onde a distinção de formação prevaleça, trazendo mais uma complexidade para o processo. A Figura 4.3 ilustra as profissões com as quais respondentes precisam interagir, segundo o levantamento efetuado. 


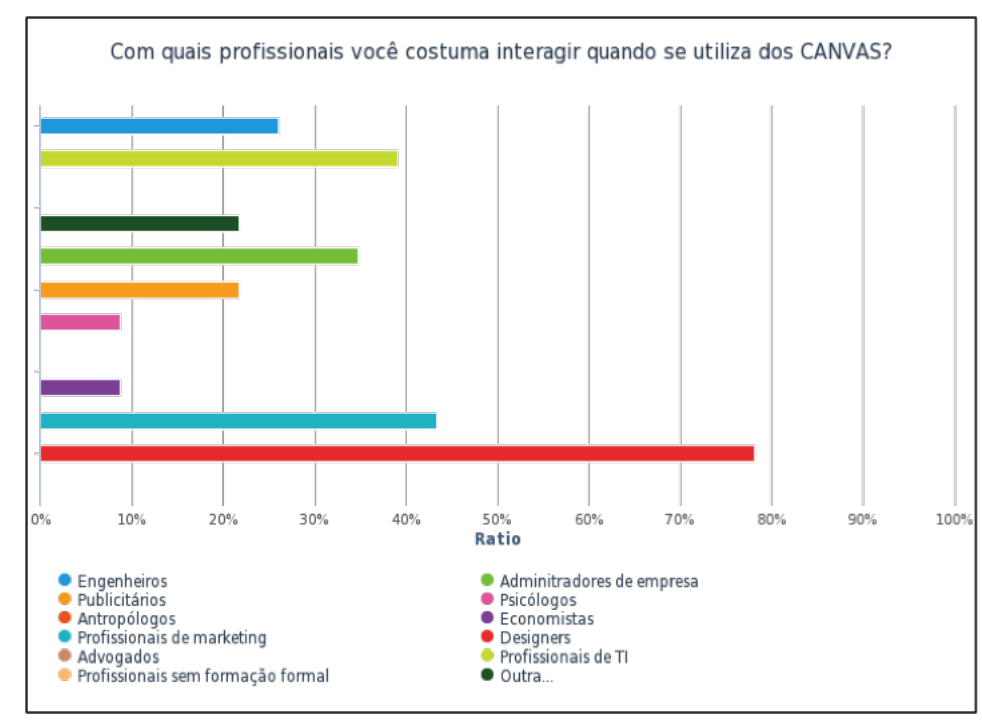

Figura 4.3: Profissionais que interagem nas atividades com os CANVAS. (Fonte: o autor)

\section{2}

\section{O segundo momento da investigação}

A investigação apresentada na seção anterior revelou que existe distinção na percepção dos CANVAS para profissionais designers comparados aos não designers, também apurou que apesar de existirem diversos CANVAS, os profissionais utilizam entre dois a três tipos de CANVAS em seus projetos de Design de Serviço. Com o objetivo de aprofundar a experiência que os profissionais possuem com os CANVAS que utilizam, tornou-se necessária a realização de entrevistas semiestruturadas, onde foram ouvidos 11 profissionais com experiência superior a cinco anos de atuação no segmento de Design de Serviço e usuários de CANVAS.

Este grupo de entrevistados também foi dividido entre designers e não designers para que se pudesse refinar as distinções entre os dois perfis profissionais, visto que isto foi identificado no primeiro momento de investigação. As entrevistas foram realizadas de forma presencial ou com a utilização de recurso de vídeo conferência, com duração de 24 a 59 minutos, e tiveram seu conteúdo gravado $^{3}$ com a devida autorização dos respondentes. As entrevistas ocorreram entre os meses de fevereiro à maio de 2020. Os pontos de interesse abordados nas entrevistas foram divididos em oito tópicos com objetivos específicos como apresentado abaixo:

- Tópico 1 - Sobre os CANVAS que usa;

${ }^{3} \mathrm{O}$ áudio da íntegra das entrevistas encontram-se no link privado https://drive. google.com/drive/u/1/folders/10guQ76_x-b7i8vQ22zXb09aww380vY10 
- Tópico 2 - Sobre a frequência que utiliza os CANVAS;

- Tópico 3 - Sobre a interação na utilização dos CANVAS;

- Tópico 4 - Sobre o tipo de projeto que utiliza os CANVAS;

- Tópico 5 - Sobre as dificuldades na utilização dos CANVAS;

- Tópico 6 - Sobre as críticas que geralmente são feitas à ferramenta CANVAS;

- Tópico 7 - Sobre as melhorias para tornar os CANVAS mais eficientes;

- Tópico 8 - Sobre a importância dos CANVAS para o projeto.

Os entrevistados foram divididos em dois grupos qualificados da seguinte forma:

- Grupo 1 - Profissionais com graduação em Design

- Entrevistado(a) 1 - gradua em 2002 pela ESDI, com formação complementar em computação e mestrado em tecnologia aplicada a arte. É funcionária de uma multinacional do setor de tecnologia. Frequentemente participa de cursos de reciclagem de Design Thinking. Trabalha com Design de Serviço há 10 anos;

- Entrevistado(a) 2 - graduada em 1991 pela PUC-Rio, com MBA no COPPEAD e outro MBA numa universidade internacional (Berlim). Atua como professora e possui uma empresa de consultoria especializada em Design de Serviço;

- Entrevistado(a) 4 - graduado em 2011 pela UERJ, atualmente é mestrando no Reino Unido. É professor de UX. Trabalha com Design de Serviço desde 2013;

- Entrevistado(a) 5 - graduada em 2005 pela PUC-Rio. Fez mestrado na Suécia em 2012. Faz regularmente cursos de curta duração no campo do design. Trabalha com Design de Serviço desde 2014. É consultora;

- Entrevistado(a) 6 - graduada em 1999 pela PUC. Fez MBA em Design Estratégico na ESPM. Faz cursos de especialização frequentemente. É gerente de um laboratório de design numa grande empresa privada. Trabalha com Design de Serviço desde 2013.

- Entrevistado(a) 8 - graduado em 2016 pela ESDI. Fez intercâmbio no Reino Unido durante a graduação em 2014 onde aprendeu Design de Serviço. É funcionário de uma grande empresa do setor de telecomunicações. Trabalha com projetos de Design de Serviço desde 2018 ; 
- Grupo 2 - Profissionais com graduação em outras áreas:

- Entrevistado(a) 3 - graduado em arquitetura pela UFRJ em 1998. Fez mestrado em Design na PUC-Rio em 2004. Fez poucos cursos pois se considera um autodidata. É um consultor e costuma dar treinamento em algumas empresas. Trabalha com Design de Serviço há 3 anos e já participou de aproximadamente 60 processos de facilitação em projetos de Design de Serviço;

- Entrevistado(a) 7 - graduado em engenharia mecânica em 1983 pela PUC-Rio. Fez mestrado e doutorado no departamento de Informática da PUC-Rio. Trabalhou por mais de 30 anos numa multinacional de tecnologia liderando diversos projetos internacionais. Faz cursos frequentemente na área de Design Thinking, cursos internacionais com ênfase em Design Thinking aplicados a problemas complexos. É sócio de uma empresa de consultoria da área de estratégia de negócios. É professor da Escola de Design Thinking;

- Entrevistado(a) 9 - graduada em pedagogia em 1990 na PUC-Rio. Fez pós-graduação em psicopedagogia no exterior. Em 2008 fez uma especialização em gestão do conhecimento. Fez mestrado em Engenharia da Produção e doutorado em Administração. Trabalha com CANVAS através de sua consultoria desde 2012;

- Entrevistado(a) 10 - graduado em administração na UFF em 2013. Fez extensão em marketing internacional no exterior. Fez cursos de especialização, dentre eles na IDEO. É um profissional de empreendedorismo. Atua como consultor e desenvolve planos de negócio há algum tempo. Também é professor de MBA nos campos de empreendedorismo e marketing;

- Entrevistado(a) 11 - graduado em engenharia elétrica, sistemas de informação e posteriormente psicologia. Tem mestrado em administração e é dourando em administração. É professor da PUC-Rio e também tem duas empresas de consultoria em inovação corporativa.

O critério de escolha dos entrevistados teve como pré-condição profissionais com os quais o autor não possuísse uma experiência profissional estabelecida, ou seja, pessoas com as quais eu nunca tivesse trabalhado anteriormente. O método de alcance aos profissionais ocorreu através de recomendações feitas por pessoas conhecidas de meu convívio social e profissionalmente. Desta forma, houve a garantia de isenção de alguma opinião que previamente pudesse existir. Os depoimentos sobre a experiência que estas pessoas possuem quanto a utilização dos CANVAS em suas práticas profissionais estão descritas na sequência deste capítulo. 


\subsection{1}

\section{A análise das entrevistas}

Para a análise dos dados qualitativos optou-se por verificar os conteúdos das entrevistas, dividindo os objetivos de cada um dos oito tópicos. A análise dos dados observou as respostas obtidas do roteiro de perguntas, norteado pelos seguintes critérios:

- Realçar os pontos relevantes em frases e expressões extraídas dos conteúdos das entrevistas;

- Expor as passagens ambíguas ou contraditórias extraídas dos depoimentos dos dois grupos de distinção designers e não designers, quando isto ocorresse;

- Identificar estruturas formais encontradas nos depoimentos, desvendando características fundamentais.

Desta forma, estes três critérios de seleção do conteúdo aplicados em cada tópico, criaram a base das afirmações dos entrevistados(as) que por final foram analisados para que se chegasse às conclusões sobre a experiência destes profissionais com os CANVAS aplicados em Projetos de Design de Serviço.

\subsubsection{1}

\section{Sobre os CANVAS que usa}

Quando perguntados sobre os tipos de CANVAS que utilizam, todos citaram pelo menos quatro CANVAS. Observou-se, contudo, que alguns entrevistados declararam criar seus próprios CANVAS, adaptar o CANVAS de acordo com o a realidade do projeto ou não achar necessário preencher algumas respostas que os CANVAS padrão já tinham. A percepção de que os campos dos CANVAS necessitam ser preenchidos com algum conteúdo, como se fossem espaços de uma espécie de prateleira é muito comum entre os designers, ficando em segundo plano a percepção de outras dimensões de resultados que a ferramenta pode proporcionar.

Alguns perguntaram no momento da entrevista, o que era considerado pelo entrivistador como CANVAS, sinalizando que uma definição do que é CANVAS nem sempre é clara para os entrevistados. O BMC (Business Model Canvas) foi citado por todos, sem que houvesse uma preferência por um CANVAS específico. Mapa de Empatia, Canvas de Persona, Blueprint e Jornada do Usuário mostraram-se CANVAS muito usados por todos os entrevistados. Mapas de Proposta de Valor (Value Proposition Canvas) somente foi citado no grupo de não designers. Este fato causou surpresa, pois este CANVAS deve ser trabalhado em conjunto com o BMC, e com outros CANVAS também, 
para que sejam definidas as funcionalidades que o produto e/ou serviço necessita ter para que a construção de valor ocorra na experiência do usuário. A Figura 4.4 ilustra este CANVAS e a Figura 4.5 ilustra de que forma este CANVAS trabalha em complemento ao BMC.

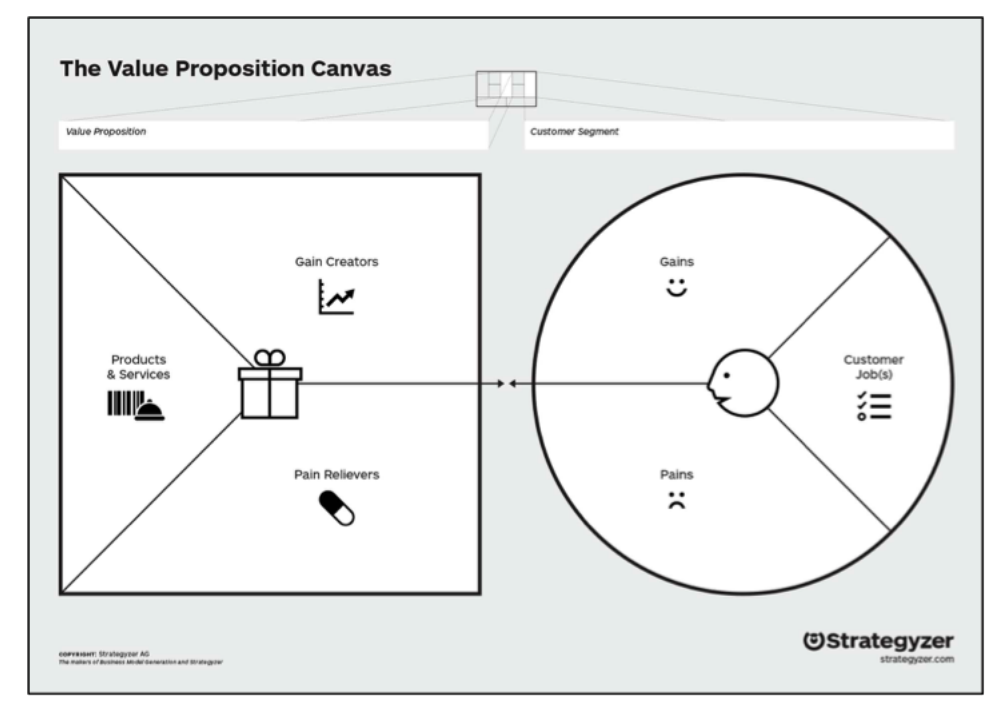

Figura 4.4: Value Proposition Canvas. Fonte:www.strategyzer.com

A maioria foi apresentada à ferramenta CANVAS em cursos de especialização ou trabalhando em empresas especializadas em Design de Serviço, não revelando ter trabalhado este conteúdo durante a graduação, mesmo para os entrevistados que se graduaram a partir da década de 2010 quando os CANVAS começaram a ser estudados na área acadêmica e utilizados pelo mercado. No caso do BMC, o livro foi a forma mais citada onde os entrevistados tiveram acesso a ferramenta, revelando o impacto que esta publicação provocou para a disseminação deste CANVAS. Muitos dos CANVAS tiveram a sua divulgação em sites e blogs sobre design e negócios, revelando a grande importância que os meios digitais possuem para o acesso a este tema.

A interação com profissionais de outras áreas do saber é comum nos projetos dos entrevistados e geralmente os CANVAS são bem aceitos por estes profissionais, sendo necessário que seja feita uma explicação detalhada sobre o manejo da ferramenta. Alguns profissionais que trabalham com os entrevistados já possuem uma ideia prévia da ferramenta CANVAS, muita das vezes distorcida quanto ao uso, dinâmica, benefícios e resultados finais. As equipes de trabalho geralmente são compostas por um mediador/facilitador, exercido majoritariamente pelos entrevistados desta pesquisa, podendo ou não ter um outro profissional para auxiliá-lo. 


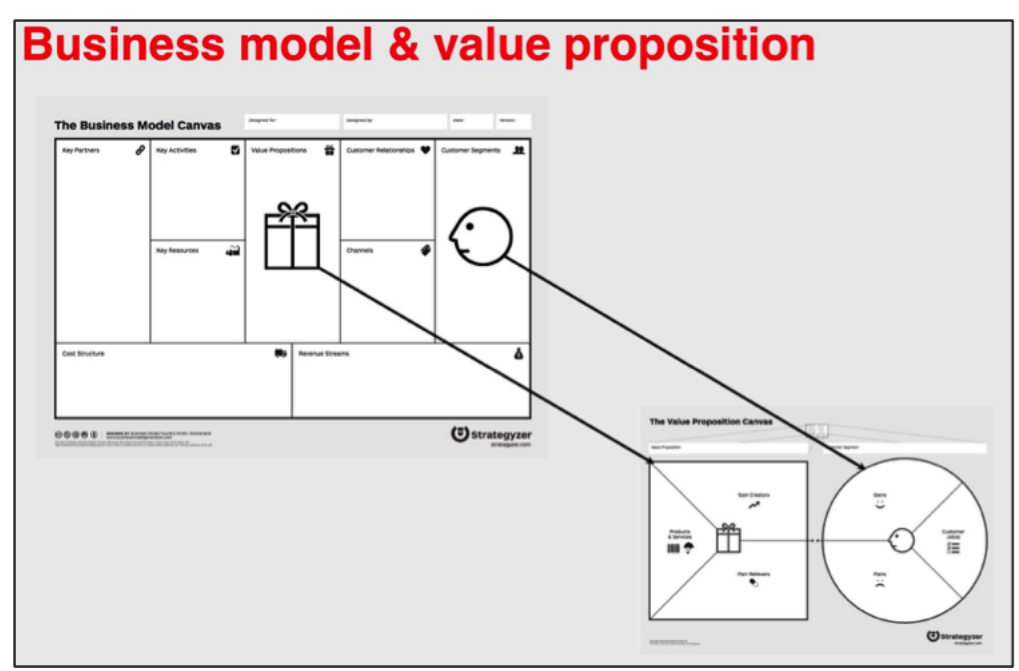

Figura 4.5: Value Proposition Canvas integrado ao BMC. Fonte:www. strategyzer.com

Dentre os principais benefícios percebidos pelos profissionais que utilizam a ferramenta está a percepção de organização das ideias, pois, como declarado por alguns, os CANVAS ajudam a colocar as coisas em seus devidos lugares, além de permitir a visão do todo, alinhar as pessoas ao desafio, colocando tudo na mesma página, por exemplo. Outra observação interessante foi a de que a ferramenta permite relatar os fatos que estão por detrás dos CANVAS, ajudando a definir uma narrativa para o processo.

Para o grupo de não designers ressalto uma citação que traduz o depoimento deste grupo:

[... "Primeiro, a experiência visual é muito forte como possibilidade de comunicação efetiva, a questão da síntese tem um impacto muito forte na produtividade e na capacidade de conversar e de trocar informação e, por trás do uso do CANVAS, sempre tem uma estratégia de trabalho. Isso é outra coisa que sempre traz um impacto."

[...] "a gente sempre está, de alguma forma, trabalhando com uma estratégia, com uma maneira de ordenar e organizar o trabalho, e isso junto com a comunicação visual e a síntese induzida pelos campos do CANVAS, sempre tem um impacto muito forte". (Entrevistado(a) 7).

Outra citação relevante, que complementa a percepção anteriormente destacada foi a de que os CANVAS permitem, segundo o Entrevistado(a) 9, "trazer a arquitetura cognitiva para se trabalhar os blocos que estão ali [...] 
é muito mais do que um papel com post-it colado, tem muito trabalho ali para saber o que escrever no post-it que eu colo ali"e que quando começam a trabalhar com a ferramenta, ela efetivamente ajuda no entendimento dos reais problemas que deverão ser tratados. O CANVAS é considerado por alguns entrevistados, como uma ferramenta simples de entender o básico do funcionamento, mas por detrás existe uma densidade muito grande, o que acaba tendo um uso muito simplista por alguns, tornando-se uma ferramenta simples, porém de um uso complexo. Podemos concluir que para o grupo de não designers, a ferramenta CANVAS direciona a comunicação para os fatores críticos que deverão estar presentes na construção da solução que objetiva a formação do grupo de trabalho.

As dificuldades mais citadas pelos entrevistados estão relacionadas com a capacidade de abstração e entendimento do problema, pois geralmente alguns Entrevistados(as) buscam trabalhar diretamente uma solução, sem entender as causas de um problema. As terminologias presentes nos CANVAS às vezes não são compreendidas, como, por exemplo, o termo Proposta de Valor que de acordo com a citação de um entrevistado ele trocou esta expressão por "Promessa de Benefício", pois entendeu que "a terminologia é uma das barreiras" com as quais frequentemente ele necessita ter que lidar (Entrevistado(a) 3).

Outro fato relevante presente no grupo dos não designers, encontra-se representado nas citações abaixo:

[... "A principal dificuldade é que um CANVAS não fala sozinho. Num primeiro momento, se o jogo não for bem combinado, quem tem menos experiência se perde um pouco. Se não for combinado pra que a gente quer usar, e onde a gente quer chegar, o que demanda um cuidado para setar o contexto que se quer usar" (Entrevistado(a) 7)

[...] "O problema está na percepção em fazer o CANVAS de forma intuitiva, e que quando se começa a fazer, surgem as dúvidas sobre o que cada um dos blocos demanda. O segundo, que é o desdobramento do primeiro, que é não explorar toda a potencialidade cada um dos blocos por não saber o que por detrás dos blocos. Não é fazer apenas uma apresentação colorida e bonitinha. Existe um conceito, uma teoria que está por trás. A ausência daquele repertório traz bloqueios ao longo do uso da ferramenta" (Entrevistado(a) 10) 
O entendimento do CANVAS como uma ferramenta de preenchimento de blocos é, em alguns momentos, o maior fator prejudicial para o seu bom uso eficiente. As consequências diretas deste mal entendimento levam a uma dinâmica de trabalho mal definida, quanto ao tempo de realização, objetivos que estão sendo perseguidos, bem como o contexto no qual estamos inseridos, transformando o CANVAS numa ferramenta simples, porém com resultados superficiais. A experiência do mediador é fundamental para que estes pontos sejam percebidos, expostos para o grupo e mediados ao longo do processo.

Para todos os entrevistados, o aprendizado da ferramenta se deu através de contato em um curso, porém o seu aprimoramento se deu na prática, não havendo a citação nas entrevistas de cursos de reciclagem para atualização ou revisão de conteúdo, principalmente para o grupo de designers.

\subsubsection{2}

\section{Sobre a frequência que utiliza os CANVAS}

A utilização da ferramenta CANVAS em projetos de Design de Serviço é muito frequente, e quando não ocorre, deve-se aos fatores principalmente ligados ao tempo ou quando a natureza do projeto não demanda inovação ou empreendedorismo. Uma das barreiras para a utilização dos CANVAS também está associado a cultura da empresa, visto que a ferramenta, em algumas dinâmicas, possui caráter lúdico, associando equivocadamente o seu uso para dinâmicas motivacionais em grupo sem que se aproveite o caráter estratégico que a ferramenta proporciona.

Quanto ao momento do projeto em que os CANVAS são usados, os respondentes citam preferencialmente os momentos iniciais, como, por exemplo, momento de diagnóstico e cocriação. Entretanto, uma citação que contradiz este uso limitado da ferramenta é a de que "os CANVAS não são camisas de força" (Entrevistado(a) 4), sendo o mais importante explorar as possibilidades de seu uso de forma não linear, como uma metodologia, e sim como algo que se utiliza em momentos e sequências diferentes.

[... "Os templates visuais, a gente usa para vender, para planejar a entrega, para executar a entrega, vários dos nossos deliverables são CANVAS. A gente usa para documentar resultados intermediários e o resultado final. A gente usa no ciclo inteiro" (Entrevistado(a) 7)

Os campos, ou blocos dos CANVAS costumam ser visitados em outros momentos do projeto ou em outras oportunidades de projeto, visto que os CANVAS podem servir como documentação de um material que registra 
um conhecimento que a empresa adquiriu durante o projeto no qual este foi empregado. Os blocos Segmentos de Clientes, Canais de Distribuição, Relacionamento com Clientes, Proposta de Valor, Fontes de Receita foram os citados como os revisitados com mais frequência. Este depoimento foi mais presente para os entrevistados que ocupam posições fixas dentro de empresas. Entretanto, raramente os designers acompanham a etapa de implementação das iniciativas geradas pelo uso das ferramentas CANVAS.

\subsubsection{3}

\section{A interação de profissionais na utilização dos CANVAS}

De acordo com os depoimentos, os profissionais de interação durante a utilização dos CANVAS são na maioria coordenadores e gerentes, ou seja, profissionais envolvidos em atividades táticas de uma empresa. Níveis hierárquicos com perfil mais estratégico, como por exemplo, diretores e alta gerência, participam em momentos pontuais, tais como kick offs do processo. Pelo recorte etário narrado pelos entrevistados, eles são pessoas de nível classificatório funcional Pleno para cima. Entretanto, dependendo da questão motivadora do CANVAS, poderão ter profissionais Juniors até Diretores, entretanto, não foi citada a mescla de níveis extremos numa mesma dinâmica.

Um ponto interessante também citado pelos entrevistados, foi a diversidade de profissionais, sendo que o viés da atuação do entrevistado, quer consultor ou funcionário de uma empresa, influencia o perfil do grupo de trabalho. A quantidade de profissionais envolvidas na interação da ferramenta fica em torno de cinco a 10 pessoas. Quando são atividades de Design Sprints ${ }^{4}$, os grupos podem chegar a 25 pessoas.

Quanto ao conhecimento dos CANVAS, todos os participantes informaram que os participantes do grupo de trabalho, por parte do cliente, já ouviram falar da ferramenta, porém sem conhecimento prático, sendo necessário desconstruir um conhecimento prévio existente para que a prática seja exercida de forma ampla e com a profundidade que a sua prática requer.

O mediador do processo, designers ou não designer, encontra dificuldades de diversas ordens para a interação com seus interlocutores. Abaixo, alguns depoimentos espontâneos colhidos dos entrevistados:

[... "eu acho que é o propósito (a maior dificuldade), eles sempre questionam se realmente é o melhor jeito de capturar, se faz sentido, o questionamento do método científico...é cultural... essa

\footnotetext{
${ }^{4}$ Design Sprint é um processo que dura entre 3 a 5 dias para responder perguntas críticas de negócios por meio do design, prototipagem e teste de ideias com os clientes. Fonte https://www.gv.com/sprint/
} 
ferramenta aí, qual é a comprovação que ela funciona?" (Entrevis$\operatorname{tado}(\mathrm{a}) 1)$.

[... "Entende com o usa (a maior dificuldade), não entendi como é que faz, não perguntam pra que que serve. Totalmente tático, ninguém tem visão estratégica... No final, eles falam: putz, construímos tudo isso, que legal. Mas eles não enxergam onde vão parar, pois eles são conduzidos pelo processo." (Entrevistado(a) 2)

[... "Quando são cargos de gerência, o entendimento deles é que um papel como esse é muito simplista perto da complexidade de um serviço. Eles acabam, por exemplo, demandando que a gente desenha Blueprints pra poder esmiuçar bem o negócio deles...a barreira (de entender) que um papel pode explicar o negócio deles" (Entrevistado(a) 5).

[...] "Viu em algum lugar (Youtube) e acha que já podem usar (a maior dificuldade). As pessoas não se dão conta do nível de planejamento que necessita para o uso da ferramenta, coleta de informações, por exemplo, e o pós também, acham que é fazer e tá pronto!...É uma coisa que eu vejo muito: é um workshopizinho de 2 horas... Tá, são 2 horas de workshop, 1 semana de planejamento mais 1 semana de síntese. As pessoas vão lá, fazem, aí não vai funcionar pra nada... aí muita gente acha que o que não funcionou foi a ferramenta"(Entrevistado(a) 6).

[... "Tomar cuidado com as generalizações (é a maior dificuldade) ...usar bem as palavras...usar informações imprecisas, que a gente queria simplificar...mas isso gera dificuldade de entendimento deles e todo método pode ficar comprometido (quanto a credibilidade)" (Entrevistado(a) 4).

[...] "Os termos... quando os CANVAS começam a ser muitos específicos de determinadas áreas. Por exemplo, Branding, que eu já rodei muitos. Quando as pessoas não são da área de marketing e comunicação começam a ficar muito mais inóspitas as questões (necessitando explicações prévias)". (Entrevistado(a) 3)

[...] "Explorar a dinâmica dos conceitos representados. Se você olhar um CANVAS vazio, ele não te diz nada... Se você olhar um CANVAS preenchido, eu diria que ele te diz pouco. O que 
eu quero dizer é que tem uma dinâmica ali no CANVAS que não é representada de alguma forma...Explorar uma camada de conhecimento que está ali representada, mas não está explícita, é difícil passar essa barreira". (Entrevistado(a) 7)

[... "A questão maior não sei se é a ferramenta em si, está no (entendimento) conceito. Por exemplo, o conceito de Valor. Se o cara não tem o conceito de que é valor ele não consegue traduzir para colocar ali no bloco de (Proposta de) Valor ... O problema é muito mais não ter um conhecimento em gestão. Se há um problema (no conhecimento) de gestão, isto se reflete no uso da ferramenta. Muitas vezes essas ferramentas necessitam ter um pré-requisito de conhecimentos que a pessoa não tem"(Entrevistado(a) 11).

Praticamente todos confirmaram a existência de conflitos entre os participantes do grupo de trabalho, que nem sempre estão muito evidentes, principalmente com participantes seniors. As divergências estão no campo das opiniões, interesses ou personalidade dos indivíduos. Segundo o Entrevistado(a) 1, "As vezes pessoas falam a mesma coisa com palavras diferentes. O meu papel é buscar uma sinergia", um depoimento que traduz algumas situações de conflito expostas pelos entrevistados. Entretanto, ao perguntar sobre a existência de alguma técnicas para a mediação de conflitos utilizadas, todos os respondentes citaram aspectos, traduzidos em expressões muito pessoais, tais como "confia em mim, vamos tentar algo diferente", "eu chego ali e tento entender o que tá rolando, mas as vezes eu deixo rolar e o conflito se resolve. As vezes eles se resolvem e em outras situações as soluções de mediação não são benvindas"(Entrevistados(as) 1 e 4). Pelas entrevistas, pode-se concluir que não há uma ferramenta, técnica ou processo definido para a mediação de conflitos, de acordo com os depoentes. Quando citada alguma habilidade, a inteligência emocional foi reconhecida como necessária para a mediação de conflitos, sendo algo muito mais intuitivo, sem um aprendizado necessário para a aplicação de alguma método que possa ser empregado nestes momentos.

O trabalho em grupo requer o máximo de participação de seus intregantes para que se consiga justificar os benefícios desta reunião de saberes. O processo do Duplo Diamante[28] estimula a divergência, ampliando o repertório de questões a serem tratadas pelo grupo de trabalho. A Figura 4.6 ilustra o Duplo Diamante extraído da publicação ciada anteriormente. A unanimidade dos entrevistados em citar que os conflitos exitem em todos os projetos onde os CANVAS são usados, sem que se haja um processo formal para mediá-los é algo que chamou a atenção, pois os métodos utilizados para a mediação de conflitos 
são intuitivos, ligados a habilidades pessoais pessoais e não construídas na formação profissional dos entrevistados.

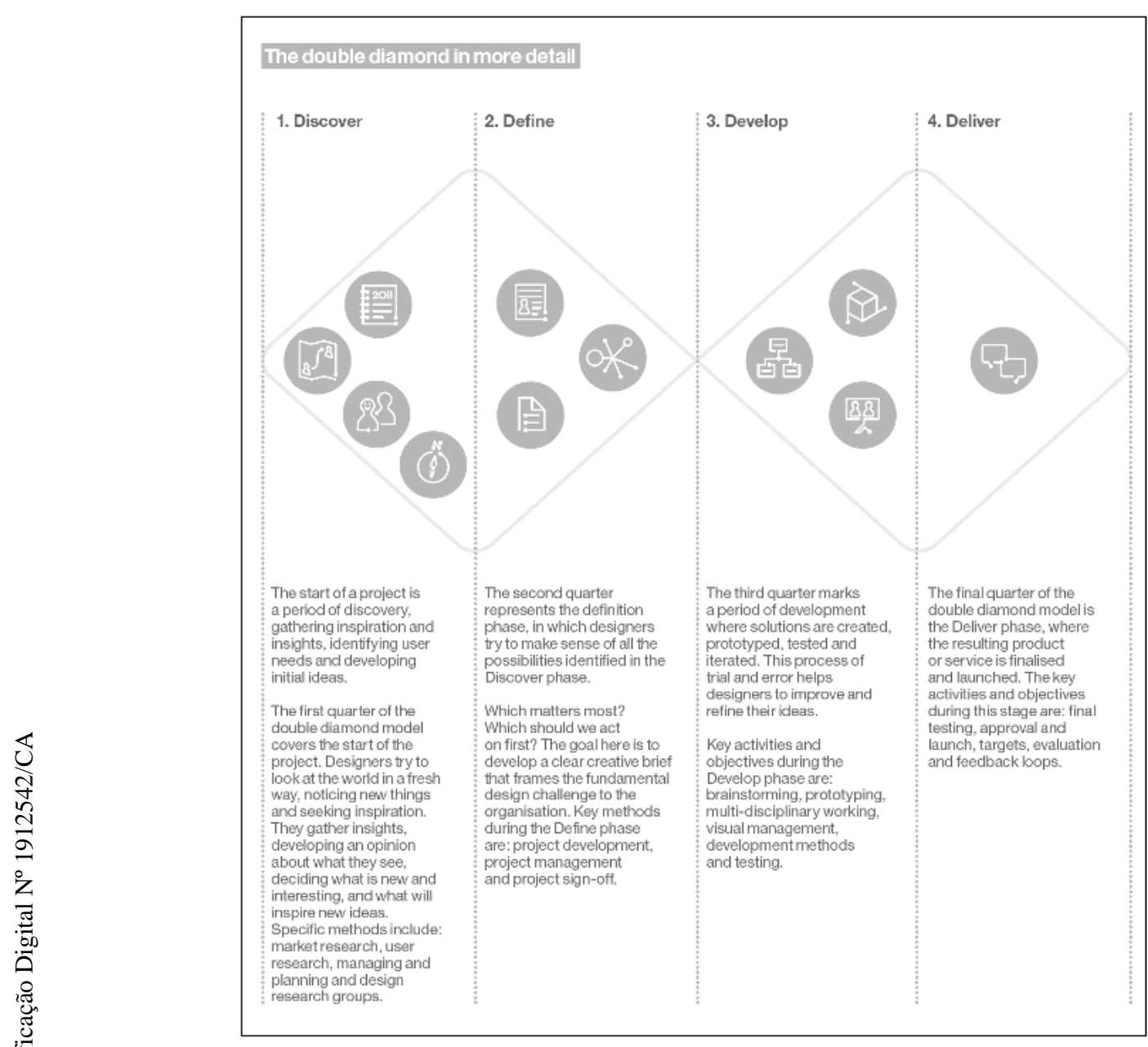

Figura 4.6: Duplo Diamante.

Fonte:www.designcouncil.uk

\subsubsection{4}

\section{Sobre o tipo de projeto que utiliza o CANVAS}

Os respondentes, em sua maioria, afirmam que os CANVAS são utilizados em projetos de média para alta complexidade e que surgem com a expectativa de solucionar alguma questão estratégica para a empresa na qual o projeto está inserido. Prazos, objetivos, o distanciamento do caminho a se percorrer entre o momento atual e o desejável pelo projeto, são determinantes para a avaliação da complexidade de um projeto, de acordo com as respostas dos entrevistados.

Outro ponto que determina a complexidade do projeto também pode estar associado a quantidade de Steakholders (partes interessadas) envolvidos no projeto, bem como a mudança de hábitos que o projeto venha a propor. 
Entretanto, pela diversidade da fala dos entrevistados, a definição de grau de complexidade de um projeto não possui uma forma de medição muito clara. A complexidade de um projeto, para alguns entrevistados está associada ao valor empregado na solução proposta. Por outro lado, outros entrevistados citam as questões associadas às mudanças de cultura com algo que torna um projeto mais complexo. Entretanto, nenhum citou a complexidade de um projeto pelos fatores internos associados ao grupo de trabalho, revelando que as características intragrupais podem estar sendo negligenciadas, ou pouco avaliadas, para que se perceba o grau de complexidade de um projeto. Sendo assim, podemos concluir pela interpretação do depoimento dos entrevistados que a complexidade é vista com algo externo ao grupo. Desta forma os conflitos intragrupais, certos de ocorrerem não são entendidos como uma um fator de complexidade que pode colocar em risco o atingimento dos objetivos do projeto.

Em sua maioria, os projetos em que o Design de serviço é aplicado resultam em serviços, que no momento em que estão em desenvolvimento são considerados estratégicos para a empresa. Os objetos resultantes dos projetos vão desde sites, aplicativos (serviços online) até o projeto de lojas, de acordo com um dos entrevistados. Entretanto, de acordo com o objeto final do projeto, os CANVAS utilizados podem variar, sendo até empregados para o desenho de processos.

A duração dos projetos varia de acordo com as empresas, de três meses a um ano, havendo P.O.C.'s (Proof of Concept, citado na entrevista 1) em vários momentos de um projeto maior, tendo CANVAS como ferramenta que faz parte deste procedimento. As áreas internas de uma empresa que mais demandam projetos de Design de Serviço com a utilização de CANVAS são Marketing, T.I. e área de Produtos/Serviços. Quanto ao segmento de mercado, esta variável muda de acordo com o perfil do consultor, assim como o tipo de CANVAS utilizado durante o projeto.

O acompanhamento da implementação do projeto modelado no CANVAS não é uma prática comum ao grupo de entrevistados, excetuando-se o Entrevistado 7, que afirma acompanhar a implementação de todos os projetos. Pelo fato de não acompanhar a implementação a maioria informou não ter acesso aos valores de investimento, nem como as distinções entre o planejado e o realizado. Os depoentes informaram que a entrega final do trabalho de Design de Serviço é um relatório com o resultado do processo para que a implementação seja realizada por terceiros, internos ou não a empresa que realizou a contratação dos serviços. Desta forma, entender as diferenças ocorridas entre o planejado e o realizado não se torna possível, limitando a visão dos profissionais entrevistados. O Design de Serviço não se restringe ao ato 
de planejar ou gerar insights para proposições de produtos e serviços. Talvez seja necessário que profissionais de design tenham atenção nesta situação que limita o campo profissional de atuação.

\subsubsection{5}

\section{Sobre as dificuldades na utilização dos CANVAS}

Os campos, ou blocos, mais amistosos nas dinâmicas com CANVAS estão associados a jornadas de usuários, quando já existe uma persona definida. Isto facilita a capacidade de interação com a ferramenta. Outra área também citada pelos respondentes é a que está associada a definição de segmentos de clientes. Alguns citaram os campos voltados a ideação e também os campos associados às dores dos clientes, que traduzem as dificuldades, ou necessidades que precisam ser atendidas para que o produto ou serviço crie valor na relação que se pretende estabelecer com o usuário. Desta forma, podemos concluir que os campos onde o cliente vê a realidade dele mais imediata e próxima, são os mais amistosos por serem tangíveis na percepção dos interlocutores. Por ser encarada como uma ferramenta de cocriação, os campos voltados a exposição de ideias também são citados como amistosos, possivelmente pelo uso de técnicas de facilitação através de imagens e desenhos que muitas vezes são empregados pelos mediadores com esta habilidade.

Proposta de Valor é um campo considerado como complexo em função de seu entendimento, requerendo que se tenha muita atenção nas mediações realizadas neste estímulo. Alguns afirmam que os seus interlocutores acabam definindo o serviço ou produto, sem perceberem que Proposta de Valor está associada a algum benefício desejado pelo usuário e que o produto ou serviço é a maneira como este benefício será entregue . Campos associados a Métricas, Estrutura de Custos e Fontes de Receita, por serem muitos técnicos e de pouco conhecimento por parte dos designers, geralmente não são aprofundados, eliminando a grande possibilidade de contribuição que os CANVAS podem proporcionar aos projetos. Os Campos Atividades Chaves e Recursos Chaves, também são citados, pois de acordo com os depoentes, os interlocutores possuem dificuldade em hierarquizar o que é necessário para entregar a Proposta de Valor do CANVAS que está sendo trabalhado.

Uma barreira citada por alguns respondentes é a dificuldade de extrair com profundidade o que os campos dos CANVAS exigem. Muitos interlocutores possuem um entendimento prévio de que os CANVAS funcionam como uma ferramenta para a aplicação de post-its, muito em função da maneira pela qual os CANVAS vêm sendo divulgados nas redes sociais.

A necessidade de traduzir questões complexas de forma sintética é 
um exercício que o mediador deve ter atenção. Quando não observados os níveis de conhecimento que os interlocutores possuem sobre os assuntos que serão tratados, o resultado tende a ser superficial. Os campos dos CANVAS falam sobre áreas que necessitam que o próprio mediador possua algum conhecimento, principalmente sobre o negócio do cliente e suas variáveis. Sem atentar para estes pontos, o resultando pode cair em descrédito, bem como os benefício que o Design de Serviço pode proporcionar para a estratégia de um negócio.

Como solução às dificuldades apresentadas nos depoimentos, alguns citam que a demonstração de exemplos, em forma de cases, pode ser interessante para auxiliar o entendimento do que venha ser Proposta de Valor. Por outro lado, esta técnica pode direcionar o grupo para um formato de proposição. Outros citam a importância de que seja realizado um bom material sobre o cenário no qual o projeto está inserido, bem como uma apresentação completa da persona do usuário ou grupos sociais para os quais estão buscando construir algo. Outra possibilidade utilizada pelos mediadores, citada por um dos entrevistados, se dá através de realização de perguntas norteadoras para facilitar o entendimento do interlocutor sobre um tema que não esteja claro no momento da dinâmica.

Todos consideram que os CANVAS são ferramentas que trazem muita contribuição para o desenvolvimento de um projeto, entretanto todos afirmam já terem passado por experiências negativas. Uma destas experiências citadas, foi a de um projeto de reestruturação organizacional de uma empresa, situação em que os participantes do projeto também eram os usuários do resultado final. Com isto, a ferramenta trouxe questionamentos intragrupais que desencadearam conflitos que não conseguiram ser mediados.

Outro ponto associado às experiências negativas estão ligadas a falta de planejamento, onde o perfil técnico e comportamental dos participantes não está devidamente mapeado. A montagem de uma agenda, que muitas vezes, por questão de tempo, não respeita a duração necessária para cada atividade, trazendo resultados pouco relevantes.

Um dos entrevistados, com larga experiência na atividade de facilitador, alertou para uma situação que deve ser evitada: um facilitador nunca deve opinar, ou propor as alternativas que o processo está apresentando. Esta atitude como facilitador, ou mediador gera assimetria de poder deste perante o grupo pela duplicidade de papeis, além do que, esta atitude faz com que seja perdido o distanciamento necessário do papel de mediador para que o trabalho tenha fluidez. O resultado, na avaliação do entrevistado, é um empobrecimento do resultado final. 
O depoimento de um dos entrevistados resume o principal cuidado que o trabalho com CANVAS requer:

[...] "Se o usuário não estiver concentrado, não sai porra [sic] nenhuma. É uma linguagem que tem muitas potências, mas ela exige alguns cuidados para funcionar bem. Se a gente não cuidar da jornada da seção, para garantir que o cliente vai estar presente, atento, desarmado, que o grupo tá a fim de trabalhar... se a gente não cuidar deste contexto, geralmente dá chabú" (Entrevistado(a) 7).

\subsubsection{6}

\section{Sobre as críticas que geralmente são feitas aos CANVAS}

A proposta para trabalhar com CANVAS geralmente é bem aceita pelo grupo de trabalho, visto que há uma febre destas ferramentas em circulação pelo mercado. Entretanto, em alguns momentos, o processo se torna pouco produtivo na visão da maioria dos entrevistados. Os campos que necessitam de maior detalhamento, e isto pode variar de acordo com o projeto, passam esta percepção de serem menos produtivos, principalmente quando os grupos são muito grandes e com um sortimento muito amplo de opiniões ou "pitacos" conforme citado por um entrevistado. O volume deste conteúdo necessitará ser editado, ou descartado, consumindo tempo na atividade de mediação, para que em seguida a consolidação do conteúdo seja validada para que outros campos dos CANVAS sejam explorados.

Outro ponto apresentado por um dos entrevistados foi a situação em que, posteriormente aos momentos muito intensos onde o grupo necessitou superar muitos obstáculos, é necessário produzir novas opções ou alternativas. Nestas situações o grupo se mantém pouco motivado a entrar em um novo processo de criação, limitando-se a ver como única alternativa possível a solução proposta no esforço anterior. O cansaço mental do grupo requer novos estímulos e que devem ser tratados com muita atenção pelo mediador ou facilitador do processo.

De uma forma geral, todos os respondentes afirmaram que as pessoas que participam das dinâmicas com CANVAS acreditam e valorizam os resultados que o uso da ferramenta proporciona.

\subsubsection{7}

\section{Sobre as melhorias para tornar o CANVAS mais eficiente}

Os CANVAS nem sempre são usados integralmente, tendo algumas campos utilizadas de forma superficial, como por exemplo, Estrutura de 
Custos e Fontes de Receita, que foram sempre são citados. De acordo com os entrevistados, eles customizam os CANVAS em função das características do cliente, público ou escopo do projeto. Um dos entrevistados, que inclusive, cita ter criado mais de 40 CANVAS, afirma que 90\% das melhorias estão associadas às nomenclaturas dos campos dos CANVAS que muitas das vezes são pouco compreendidas pelos seus usuários.

Foi ainda um ponto comum no depoimento dos entrevistados a afirmação de que os CANVAS geralmente sofrem adaptações para buscar mais sintonia com o escopo dos projetos. Alguns depoentes afirmam que os campos relacionados a Finanças são tratados de forma superficial e com pouco embasamento nas sugestões que o grupo faz durante a dinâmica. Outra recomendação de mudança proposta por um dos entrevistados, foi a criação de campos, ou de uma ferramenta associada ao CANVAS, para explorar um pouco mais as características da equipe que atuará na solução proposta, registrando, por exemplo, a forma como os colaboradores irão interagir durante o processo de entrega do produto ou serviço, o que permite desfocar o olhar do usuário para a força de trabalho.

A habilidade de representar graficamente ideias é muito importante para tornar as seções mais dinâmicas. Entretanto, nem sempre esta linguagem é familiar aos participantes, sobrecarregando o trabalho do facilitador para desempenhar este papel. Uma sugestão de um dos entrevistados foi a criação de um glossário visual para suportar estas iniciativas e alinhar o entendimento sobre os códigos visuais ali empregados.

As ferramentas complementares aos CANVAS que são de caráter colaborativo e que foram citadas são:

- Ferramentas para mapa mental, que permitem registrar visualmente a linha de um pensamento de um depoimento, ou até mesmo para expressar um caminho de uma proposta de trabalho;

- Trello, para a organização de tarefas;

- Miro (Free Online Collaborative Whiteboard Plataform), muito utilizado para trabalhar colaborativamente;

- Lego Serious Play para dinâmicas de facilitação de processos, que se utilizando dos blocos de encaixe coloridos, o propósito de um projeto pode ser construído em vez de falados. 


\subsubsection{8}

\section{Sobre a importância dos CANVAS para o projeto}

$\mathrm{Na}$ opinião dos entrevistados, os CANVAS trouxeram uma visão estratégica para a prática projetual, permitindo que o Design leve o seu método para outras áreas do conhecimento. Outra característica apontada pelos entrevistados foi a possibilidade de desenvolvimento pessoal da habilidade para trabalhar em grupo, sendo necessário que se coloque em prática as competências associadas ao campo do comportamento humano. Esta condição apontou para a necessidade de melhoria na comunicação entre pessoas que trabalham no grupo e, quando concluído o trabalho, a comunicação com o grupo social que orbita entorno do projeto. Pelo que observado na fala dos respondentes, os CANVAS trazem a possibilidade de melhorar a eficiência de comunicação entre os membros do grupo de trabalho e do grupo para os Steakholders do projeto, visto que os CANVAS classificam as informações por áreas de interesse, direcionando a atenção nos momentos em que o esforço intelectual necessita ser empregado, e por fim, apresentam as conclusões que o processo colaborativo atingiu.

Os entrevistados apontaram que os CANVAS contribuem para estruturar as informações de um projeto, pois em suas dinâmicas se exercita a análise de situações, o confronto de pontos de vista, a análise de dados e o formato da documentação. Em suma, dar "caixinha para as coisas para ajudar as pessoas terem mais clareza sobre a complexidade dos desafios a serem superados, visto que muitas informações encontram-se dispersas" (Entrevistado(a) 10).

Da fala dos entrevistados pode-se depreender que os CANVAS são fundamentais para a organização das informações, alinhamento da equipe de trabalho e entendimento dos reais problemas a serem enfrentados durante o projeto, visto que em processos participativos torna-se fundamental ter clareza sobre estes pontos para que o trabalho consiga manter o grupo unido e comprometido no mesmo propósito que objetivou a formação do mesmo.

Todos os entrevistados alegam grandes contribuições que os CANVAS proporcionaram aos seus projetos. Os designers, enfatizam o aspecto metodológico, aplicados no processo de cocriação que os CANVAS possibilitam, além de elevar a aplicação do Design para o nível estratégico de uma empresa. Além disso, os CANVAS permitem perceber a inteligência do coletivo e possibilitam que a equipe se organize de forma operativa. Os CANVAS permitem, para a maioria dos entrevistados, hierarquizar os inputs para em seguida direcionar os outputs de um esforço coletivo. Desta forma, o grupo ganha capacidade de avaliar os Fatores Críticos para o Sucesso (FCS) do projeto, determinando o ponto de maturidade que uma proposição idealizada pelo grupo tenha alcan- 
çado para ser submetidas à etapa de iteração com o grupo, ou se for a escolha , com o próprio usuário. Desta forma, podemos considerar que os CANVAS possibilitam que se estabeleça o MVP (Mínimo Produto Viável) de um projeto, para que se possa ter os feedbacks do usuário sobre aquilo que se pretende empreender.

As entrevistas realizadas trouxeram à tona aspectos importantes sobre a utilização de CANVAS, que podem ser resumidos nos seguintes pontos:

- Através desta ferramenta é possível construir o mapa do pacto que está sendo estabelecido para a construção de algo coletivo;

- As teses apresentadas pelos participantes das dinâmicas, em muitas das vezes, se transformam em antítese por divergências de interesses, saberes ou pontos de vista;

- Os CANVAS proporcionam condições para que se encontre uma convergência destes caminhos, resultando em sínteses sobre as questões discutidas em cada bloco;

- O ancoramento na ferramenta, em seu formato original (aquele que o autor apresenta para o mercado), pode afastar a equipe do entendimento de que esta serve para ajudar a solucionar problemas;

- O mau uso da ferramenta pode levar a equívocos durante o processo de mediação, em função do desencontro de pontos de vista;

- O bom uso do CANVAS está em conseguir extrair da equipe o somatório de seus conhecimentos, servindo como ferramenta de decisão durante o desenvolvimento de um projeto.

As duas etapas da pesquisa revelaram a experiência que profissionais que trabalham com Design de Serviço possuem com a utilização dos CANVAS. Podemos afirmar que as ferramentas trazem grandes contribuições para o processo do Design, permitindo que designers dialoguem com outras áreas do conhecimento de forma ordenada, facilitando o entendimentos da complexidade presente na busca de soluções de algo que se pretenda empreender.

O trabalho colaborativo e participativo encontra nos CANVAS um espaço para a produção de debates que por hora são divergentes, mas que necessitam convergir de forma sintética no formato que os CANVAS propoem. Entretanto, sa entrevistas apresentaram que os CANVAS são ferramentas e que a forma como estão sendo usadas pode revelar algo que vai além dos campos que grupo busco preencher. O uso dos CANVAS em projetos de Design de Serviço abrem vários canais de comunicação entre os integrantes do grupo de trabalho, revelando as complexidades não visíveis, e que talvez necessitam ser 
"domesticadas"com habilidades que ainda não possuem um formato definido. Um projeto inicia com muitas incertezas, de diversas naturezas, a começar pela complexidade de esforços necessários para a sua concretização. Os CANVAS ajudam a tangibilizar esta complexidade, pois, a forma de ferramenta visual facilita a reflexão do grupo de trabalho, mostrando uma visão holística sobre a situação onde se busca empreender. Projetos de Design de Serviço sem a utilização das ferramentas CANVAS correm o risco de se transformar em propostas projetuais incompletas, ou pouco exequíveis por não receberem os estímulos que a ferramenta propõe.

Por outro lado, as ferramentas também mostram a necessidade de outras capacidades que não estão presentes em sua prática formal, como por exemplo a mediação necessária para solucionar conflitos intragrupais, certos de ocorrerem. Para a prática da mediação talvez o designer necessite receber algum treinamento durante a sua formação, para que tenha habilidades e consiga convergir os interesses do grupo de trabalho, independente se ele ocupar o papel de líder de projeto, ou meramente um membro de um grupo operativo.

No capítulo seguinte será observado o quanto que as oportunidades vividas em sala de aula no curso de Design podem ser exploradas para que designers se capacitem para trabalhar com ferramentas CANVAS, extraindo o máximo que a ferramenta pode proporcionar. 


\section{5 \\ O mercado e a sala de aula: oportunidades a serem exploradas na formação de designers}

Nos capítulos anteriores foi retratada a origem do Design de Serviço, apontando os CANVAS como ferramentas sempre presentes para facilitar o processo de interação com grupos de pessoas. A proliferação dos CANVAS ajudou a disseminar práticas projetuais mais colaborativas, havendo CANVAS para atender às necessidades específicas de diversos segmentos de mercado, sendo utilizado em momentos onde se necessita criar algo com profissionais com conhecimento complementar. A experiência com os CANVAS foi investigada em pesquisas onde diversos profissionais, designers e não designers expuseram as suas opiniões sobre o uso da ferramenta nas suas experiências práticas, revelando haver algumas distinções e também muitas semelhanças na visão dos que foram ouvidos. Neste capítulo serão abordados os pontos de contato entre a prática de mercado e a prática em sala de aula, objetivando encontrar oportunidades a serem exploradas na formação acadêmica de estudantes que desejam trabalhar com Design de Serviço.

\section{1}

\section{A prática de mercado do design de serviço}

As entrevistas confirmaram que o Design de Serviço é um segmento de atuação que aproxima o design das questões estratégicas de um negócio. O processo colaborativo que o Design de Serviço sugere, expõe a necessidade do desenvolvimento de habilidades que permitam aos designers conseguirem extrair a plenitude dos benefícios de se trabalhar em grupo. Entretanto, em muitas situações, o designer é um profissional externo ao grupo, com menor repertório sobre questões ligadas ao negócio no qual uma empresa opera, tais como, o segmento de mercado, a concorrência, a cultura corporativa e o comportamento humano de um grupo social que possivelmente já se conhece ou possui alguma experiência prévia de trabalhar em equipe. E isto é uma fragilidade que deixa o designer exposto, podendo ser um fator que contribua para que o seu desempenho não esteja à altura daquilo que ele pode oferecer.

A aplicação eficiente de métodos para investigação dos hábitos dos usuários, estabelece a dimensão que uma solução necessita ter nos momentos 
de uso prático de um objeto ou serviço, trazendo para o grupo de trabalho o olhar empático para o indivíduo. Podemos afirmar que esta é uma grande contribuição esperada no resultado obtido por projetos de Design de Serviços, sendo citada em todas as entrevistas, por designers e não designers . A utilização do Customer Journey Canvas é um exemplo onde, em grupo, se busca encontrar as tarefas que o usuário realiza, estabelecendo os pontos de contato a serem transformados numa experiência mais adequada, dando forma e personalidade às condições de uso que o usuário deseja. Entretanto, para que o grupo adquira este saber, os designers se utilizam de métodos de pesquisa para observar, vivenciar, registrar e perguntar sobre rotinas, hábitos, desejos e significados que serão as bases das decisões que o grupo venha a tomar ao longo do processo de trabalho. Desta forma, a mediação do designer se torna fundamental para articular o equilíbrio entre as necessidades do usuário, a vontade do grupo de trabalho e o interesse da empresa contratante em adotar a melhor solução possível para o usuário final.

A complexidade que o ambiente de um projeto de Design de Serviço proporciona, pode estar associada a forma como este grupo será conduzido, pois nele encontram-se pessoas que representam áreas de uma empresa, lideranças de grupos sociais, especialistas com saberes específicos, que se manifestam durante o processo grupal para sustentarem as suas posições dentro da instituição as quais pertencem, bem como as suas convicções e valores sociais. Se analisarmos a situação sob a ótica da discussão proposta de Buchanan[17], um problema pode ser encarado como uma situação multifacetada, que de acordo com os pontos de vista de um observador, podemos encontrar caminhos distintos na forma de solucioná-los. Entretanto, uma solução proposta pode criar novos problemas que necessitam ser pensados em outra dimensão do estado das coisas. Host Rittel e Melvin Webber no artigo "Dilemmas in a General Theory of Planning"[24], introduzem o termo "Wicked Problem" para chamar a atenção para a complexidade dos desafios de abordar problemas que impactam grupos sociais, necessitando se estabelecer com clareza os seus objetivos, na busca de uma articulação interna para encontrar uma lógica para a tomada de decisões.

Problemas complexos são multidisciplinares, multifatoriais e multifacetados, onde a abordagem colaborativa é a maneira que o Design encontrou para solucioná-los e requer, portanto, novas habilidades do designer na condução de projetos, conforme descrito na citação abaixo:

"Fertilizando e deixando fertilizar-se por outras áreas do conhecimento, o Design vem se construindo e reconstruindo em um processo permanente de ampliação de seus limites. Em linha com 
essa tendência, sua vocação interdisciplinar impede o fechamento em torno de conceitos, teorias e autores exclusivos. Sua natureza multifacetada exige interação, interlocução, parceria." [19].

A atuação centralizadora, como um decisor do grupo de trabalho que designers podem assumir em projetos de Design de Serviço é uma visão equivocada da multidisciplinaridade atribuída a sua atividade. O papel de decisor requer múltiplos conhecimentos necessários para que esta atuação seja eficiente, e que talvez seja mais adequada para profissionais com algum grau de senioridade ou talvez para algum membro externo ao grupo de trabalho. O caráter multidisciplinar atribuído ao Design proporciona condições deste ser um articulador de pensamentos, alinhando interesses e desejos para em seguida dar forma aos avanços pactuados pelo grupo de trabalho. Entretanto, se considerarmos que a multidisplinaridade requer o saber profundo sobre várias áreas do saber, designers necessitariam ter uma formação tão ampla que dificilmente caberiam nos cinco anos que atualmente são necessários para a conclusão do curso de graduação. Talvez por isso a expressão "fertilizando e deixando fertilizar-se" seja uma reflexão importante que designers terem em mente quanto ao seu papel dentro dos grupos de trabalho.

\section{2}

\section{A habilidade para mediar conflitos}

Uma habilidade fundamental para que este ambiente se concretize está na capacidade em dialogar de forma fluida entre os diversos saberes, interesses e desejos, construindo conhecimento para ele e para o grupo ao longo do ciclo de vida do projeto. Com as dinâmicas altamente participativas, projetos ganham complexidade a medida em que avançamos na busca de uma solução, gerando uma grande oportunidade de crescimento para todos os envolvidos em sua realização. Por outro lado, quando não percebemos esta necessidade de interlocução ativa entre o grupo de trabalho, podemos perder a participação de seus integrantes a medida que os processos decisórios não são mediados de forma eficiente. Desta forma, a evolução dos trabalhos exclui a participação de seus integrantes, diminuindo a riqueza intelectual gerada pelo somatório dos saberes que os processos colaborativos possibilitam.

Com a diversidade de saberes e olhares em ambientes multidisciplinares, multifatoriais e multifacetados, reforça-se então a figura do designer como mediador, não apenas pelo processo divergente estimulado no Duplo Diamante 1 , mas pela arquitetura social do grupo de trabalho constituído, e que certamente influenciará o formato final da solução proposta. Segundo o dicionário

${ }^{1}$ 2005. Design Council UK 
Michaelis[21], mediação pode ser definida como o processo criativo por meio do qual se passa de um termo inicial a um termo final, e mediar é estar entre duas coisas ou dois extremos. Esta definição de mediação evoca uma evolução, e traz uma prática aderente ao campo do Design, qual seja o processo criativo. A mediação não é somente importante quando ocorrem conflitos por divergência, que são vitais, mas obviamente na condução para uma solução perseguida durante todo o processo do trabalho grupal.

"Mediar relações humanas é parte fundamental do trabalho de um designer. É dever do designer ser gestáltico em empatizar e entender as informações contidas nas relações que irão surgir entre a sua equipe e seu usuário. Com isso, é possível perceber e filtrar os valores que surgem dos choques positivos e negativos dessas relações. São os choques entre as crenças e percepções dessa equipe que, juntamente com o usuário, minimizam e, em muitos casos, eliminam a criação de algo perceptivelmente irrelevante para a sociedade."[21]

Com a utilização dos CANVAS, ferramentas sempre utilizadas em projetos de Design de Serviço, o conflito de interesses surgirá naturalmente, pois ter ideias alinhadas não é uma pré-condição para participar de grupos de trabalho, pois a divergência de pontos de vista, culturas, comportamentos, interesses e saberes são fertilizantes para o processo grupal. Esses conflitos, não sendo mediados, podem ser transformados na polarização de um processo sem que este encontre a convergência no somatório dos saberes das áreas e pessoas envolvidas, e com isso as proposições sugeridas pelo projeto perdem força para serem de fato inovadoras.

A necessidade de trazer a divergência para o processo do Design, está presente no Duplo Diamante, criando um primeiro momento onde se busca descobrir conteúdos valorosos, obtidos pela diversidade de pontos de vista para revelar as possibilidades a serem trabalhadas. Num segundo momento, essa diversidade de conteúdos necessita convergir para que o processo evolua em grupo. É exatamente neste momento, onde as divergências são potencializadas, que o designer poderá atuar mais profundamente como mediador para a consolidação de algo desejado, utilizando em diversas situações, conforme citado nas entrevistas, técnicas de facilitação para encontrar os caminhos de convergência, alinhando o grupo de trabalho e avançando no processo projetual.

As divergências certamente irão surgir, estimuladas por conflitos de interesses entre participantes do grupo de trabalho, por pontos de vista 
sobre questões polêmicas ou por aspectos comportamentais dos indivíduos quando trabalhados em grupo. Entrar no conflito, pode não parecer uma boa opção para o designer ou qualquer pessoa que assuma o papel de manter as pessoas ativas e produtivas, trabalhando e criando na direção do objetivo que motivou a sua formação. A habilidade para mediar conflitos se faz necessária, porém esta competência é pouco debatida, estudada e encarada como algo em que se necessita treinar os profissionais que desejam trabalhar com grupos multidisciplinares e de alto grau de conhecimento em suas áreas de conhecimento, e talvez tenhamos aqui uma competência a ser trabalhada na formação de designers.

Cabe ressaltar que assim como Gomes e Silva colocam, Simmel destaca que a ausência de concordância pode não ser boa:

[...] "Se toda interação entre os homens é uma sociação, o conflito - afinal, uma das mais vívidas interações e que, além disso, não pode ser exercida por um indivíduo apenas - deve certamente ser considerado uma associação [...] O conflito está assim destinado a resolver dualismos divergentes; é um modo de conseguir algum tipo de unidade, ainda que através da aniquilação de uma das partes conflitantes [...] O conflito contém algo de positivo. Todavia, seus aspectos positivos e negativos estão integrados; podem ser separados conceitualmente, mas não empiricamente". [26]

Devido ao CANVAS servir como base para formulação de estratégias e serem implementadas por equipes de alto nível, o conflito tende a existir, mas também tende a ser resolvido com alto grau de proveito para o todo. $\mathrm{Na}$ ausência de conflito, existe uma grande chance de se estar convergindo cedo demais, perdendo o contraponto criativo de ideias. Como lembra Edgar Morin:

[... "modos simplificadores de conhecimento mutilam mais do que exprimem as realidades ou os fenômenos de que tratam, tornando-se evidente que eles produzem mais cegueira do que elucidação."[23]

Até que ponto as ferramentas usadas para trazer uma visão holística devem ser somente facilitadores para o entendimento de questões complexas? A utilização destas, sem que se promova o conflito entre as partes, faz com que todo o processo corra o risco de tornar a discussão superficial, tendo como consequência soluções pouco abrangentes, abreviando o seu tempo de uso.

Podemos considerar que com o uso dos CANVAS como ferramentas para o processo do pensamento do Design, praticamos métodos de criação coletiva, 
Capítulo 5. O mercado e a sala de aula: oportunidades a serem exploradas na formação de designers

exigindo a atuação intensa dos participantes do grupo formado. Entender suas paixões e anseios pode ser uma importante tarefa a ser realizada para que consigamos somar os saberes contidos na experiência que cada um carrega em seu repertório de vida.

Os métodos de criação coletiva, apontam para oportunidades, ou melhor, necessidades nas quais o Design poderá assumir novas responsabilidades. A exemplo disso, a facilitação já vem sendo empregada há tempos, porém a mediação de conflitos ainda não é percebida com algo que designers possam fazer. Os conflitos de interesses, de pontos de vistas, de culturas, de formação, fora outros mais que possam existir em cenários diversos, apresentam grande potencial a ser trabalhado, onde a mediação é fundamental para se buscar o somatório dos saberes presentes no grupo de trabalho.

Mediar conflitos passa por entender os interesses e paixões dos envolvidos para encontrar os pontos de convergência, com o intuito de buscar caminhos onde o somatório destas questões permita que todos participem ativamente, e no mesmo grau de engajamento ao longo do processo. Também se torna necessário entender o esforço dos indivíduos para se manterem participantes no processo, assim como a mediação das expectativas de retornos esperados é fundamental para que não haja frustrações ao término do projeto, de modo a evitar que a experiência do "projetar com" se transforme em algo traumático ou pouco interessante para experiência futuras.

A liderança do Design neste processo poderá estar no esforço em construir uma arquitetura social que permita que conflitos ocorram de forma menos pessoal, percebendo que a oposição é algo importante para processos onde a diversidade está presente. No modelo do Duplo Diamante a divergência é um princípio para que, na sequência, a convergência aponte caminhos para a evolução, usando técnicas de facilitação para entender as variáveis pesquisadas, clarear os caminhos a serem perseguidos, visualizar as alternativas propositivas. Porém, corremos o risco da facilitação não ser eficiente para mediação de conflitos, alijando do processo aqueles que por algum motivo, desistam de sustentar os seus pontos de vista.

O Design, à medida que insere novos ingredientes ao seu processo, tornase complexo, recebendo inputs de informação de várias origens e sentidos. Inputs podem ser originários de experiências individuais anteriores, da troca de informações entre participantes, do contexto em que o projeto está sendo desenvolvido, do desenrolar projetual, dos testes e aplicações, enfim, de muitos outros fatores. Tudo isto faz com que, quanto mais diversos forem os participantes da criação coletiva, mais vetores de conhecimento irão interferir num eixo central, que é a razão pela qual o grupo foi formado para trabalhar em 
Capítulo 5. O mercado e a sala de aula: oportunidades a serem exploradas na formação de designers

conjunto.

Essa rede de trocas e de compartilhamentos estimula a criação de um produto rico, imerso nas experiências e conhecimentos simbólicos, culturais e subjetivos tanto individuais como coletivos. Torna-se um produto que não possui um viés individualista e autoral; na verdade é resultado daquela parceria e de todas as trocas intersubjetivas. E quando os vetores de conhecimento colidem, significa que interesses são conflitantes, necessitando haver a mediação para que o projeto possa prosseguir na direção da linha lógica pré-estabelecida e pré-acordada para a formação do grupo, fazendo com que o grupo se mantenha ativo e participante. A Figura 5.1 foi concebida de forma a ampliar, ou elucidar o que faz a trajetória ser excessivamente sinuosa para explicar métodos de criação coletiva, nos quais os CANVAS se apresentam como ferramentas, tendo como ponto crítico o conflito, que pode mudar a trajetória da linha lógica de formação do grupo.

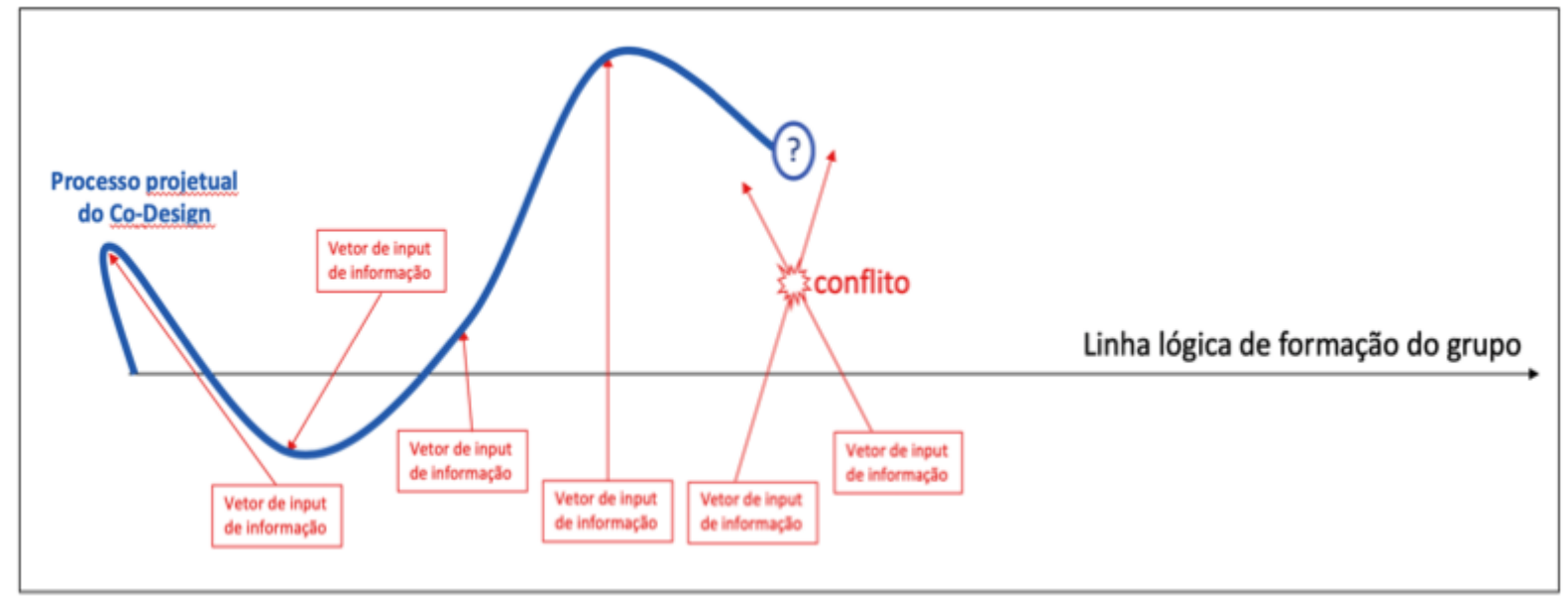

Figura 5.1: Processo projetual do Co-Design

A mediação é uma atitude desejada e poderosa para a obtenção do somatório dos saberes, onde o Design exerce um papel diferenciado, que já está presente em sua vocação transdisciplinar, aplicado na busca por solução para problemas complexos. Entender que o antagonismo de ideias, assim como a mediação são inerentes à essa busca, será um passo na direção da obtenção de melhores resultados.

Quanto mais participativo for o processo, mais ele refletirá a representatividade da diversidade cultural nas soluções, minimizando a possibilidade da irrelevância que o resultado do projeto significará para o grupo social ao qual se destina, e para isto, a quantidade de conflitos pode ser um indicador de participação de seus integrante. Entretanto, sem que alguém seja treinado para 
Capítulo 5. O mercado e a sala de aula: oportunidades a serem exploradas na formação de designers

assumir o papel de mediador, os conflitos serão evitados, pois estão associados a algo negativo e indesejável.

\section{3}

\section{A prática da sala de aula}

O ambiente de sala de aula oferece desafios na construção de conhecimento para alunos que chegam ao curso com múltiplas expectativas. Um dos desafios encontrados logo de início do curso está do entendimento dos limites da atuação profissional do Design. Uns buscam no curso uma forma de aprimorar vocações artísticas, outros as suas vocações empreendedoras e muitos encontram-se perdidos, pois o ingresso pode ocorrer quando os jovens encontram-se ainda imaturos e desestruturados para definir sobre uma escolha que norteará o que os consumirá entre quatro e cinco anos de suas vidas. A escolha por um curso, quando não manifestado o caráter vocacional, pode se dar por questões financeiras, por tradição familiares, por resultados dos pontos obtidos no ENEM, enfim, cada aluno que ingressa no ensino superior pode ser encarado como uma caixa de surpresas e que, no caso do Design, o desafio ainda é maior pois "o que é isso que chamamos de Design?" Será que os que ingressam neste curso possuem conhecimentos sobre o universo de sua prática?

\subsection{1}

\section{As definições da prática da atuação do Design}

Numa definição da World Design Organization, Design é um processo estratégico de soluções de problemas que impulsiona a inovação, constrói o sucesso de um negócio e leva a uma melhor qualidade de vida por meio de produtos, sistemas, serviços e experiências inovadoras. O Design preenche a lacuna entre o que é e o que é possível. É uma profissão transdisciplinar que aproveita a criatividade para resolver problemas e co-criar soluções com a intenção de tornar melhor um produto, sistema, serviço, experiência ou negócio. Na sua essência, o Design oferece uma maneira mais otimista de olhar para o futuro, transformando problemas em oportunidades. Ele conecta inovação, tecnologia, pesquisa, negócios e clientes para fornecer novo valor e vantagem competitiva em todas as esferas econômica, social e ambiental.

$\mathrm{Na}$ definição da Interaction Design Foundation, o Design de Serviço é um processo no qual o designer se concentra na criação de experiências de serviços ideais. Isso requer uma visão holística de todos os atores relacionados, suas interações e materiais de apoio e infra-estruturas. O Design de Serviço geralmente envolve o uso de mapas de jornada do cliente, oferecendo assim insights profundos. 
De acordo com o parecer do Conselho Câmara de Educação Superior / Conselho Nacional de Educação de número 0195/2003, o artigo 4 [27] afirma que o curso de Design deve possibilitar a formação profissional que revele competências e habilidades para:

I. Capacidade criativa para propor soluções inovadoras, utilizando domínio de técnicas e de processo de criação;

II. Capacidade para domínio de linguagem própria expressando conceitos e soluções, em seus projetos, de acordo com as diversas técnicas de expressão e produção visual;

III. Capacidade de interagir com especialistas de outras áreas de modo a utilizar conhecimentos diversos e atuar em equipes interdisciplinares na elaboração de pesquisas e projetos;

IV. Visão sistêmica de projeto, manifestando capacidade de conceituá-lo a partir da combinação adequada de diversos componentes materiais, processos de fabricação, aspectos econômicos, psicológicos e sociológicos do produto;

V. Domínio das diferentes etapas do desenvolvimento de um projeto, a saber: definição de objetivos, técnicas de coleta e tratamento de dados, geração e avaliação de alternativas, configuração de soluções e comunicação de resultados;

VI. Conhecimento do setor produtivo de sua especialização, revelando sólida visão setorial, relacionado ao mercado, materiais, processos produtivos e tecnologias abrangendo mobiliário, confecção de calçados, joias, cerâmicas, embalagens, artefatos de qualquer natureza, traços culturais da sociedade, softwares e outras manifestações regionais;

VII. Domínio de gerência de produção, incluindo qualidade, produtividade, arranjo físico da fábrica, estoques, custos e investimentos, além de administração de recursos humanos para a produção;

VIII. Visão história e prospectiva, centrada no aspecto sócio-econômico e culturais, revelando consciência das implicações econômicas, sociais, antropológicas, ambientais, estética e éticas de sua atividade.

Para este super profissional atuar de forma satisfatória, norteados pelas exigências da prática do Design e do Design de Serviço, bem como pelas qualificações definidas pelo CES/CNE para o curso de Design, deve possuir 
Capítulo 5. O mercado e a sala de aula: oportunidades a serem exploradas na formação de designers

um universo com atuação ampla, tornando ainda mais difícil a sua formação, tendo a sala de aula como um principal ponto de contato para construção de algum saber.

Não há dúvida quando a capacidade criativa que um designer necessita ter para exercer a profissão. Durante a formação acadêmica várias técnicas são ensinadas para serem. Estes métodos que estimulam a criatividade são exercitados nas disciplinas de projeto, onde o objetivo está em fazer com que o estudante adquira o hábito de lidar com o desafio de fazer com que grupos de pessoas construam soluções para problemas reais com o uso da criatividade, que muitas vezes encontra-se adormecida por um julgamento provocado pela racionalidade e pragmatismo. O aluno praticamente exercita o ato de criar, desenhando, entrevistando, vivenciando, conceituando e prototipando suas ideias durante os 4 anos do curso, percebendo estas tarefas, como fundamentais para o bom desempenho da função de designer que projeta para a sociedade.

Somada a complexidade da atribuição como ser criativo do designer, se aproxima mais uma habilidade não citada nas definições dos CES/CNE, mas fundamental para interagir com pessoas para construir soluções para um mundo complexo: a mediação de conflitos.

\subsection{2}

\section{As disciplinas realizadas em grupo no curso de Design}

Os trabalhos em grupo ocorrem praticamente ao longo dos anos dos cursos de graduação de Design em geral. Estes grupos são formados por alunos que se juntam estimulados por diversos fatores, como perfis complementares de habilidades individuais, interesses por um determinado tema pactuado em sala de aula, proximidade de moradia, experiências anteriores entre os indivíduos e por uma infinidade de fatores de ordem racional e emocional.

Entretanto, a atividade de projetar em grupo expõe o aluno, ainda em formação, situações que se assemelham a prática profissional onde conflitos intragrupais são comuns de ocorrer. Somado a isto, quando as ferramentas CANVAS são apresentadas aos alunos, estes descobrem uma maneira sistematizada de pensamento para a construção de uma solução de forma menos intuitiva, revelando a complexidade de fatores que devem ser considerados na construção de uma solução. A busca por respostas que atendam aos requisitos das ferramentas acaba fazendo com que o seu uso seja percebido como um preenchimento dos campos dos CANVAS, sem que ocorra uma reflexão profunda sobre o significado do que está sendo estimulado a se pensar.

Quando os alunos estão mais atentos para o que os CANVAS propõe como reflexão, isto cria situações de conflitos intragrupais, evitados por to- 
Capítulo 5. O mercado e a sala de aula: oportunidades a serem exploradas na formação de designers

dos, professores e alunos, por perceberem como algo negativo e associado a personalidade de seus integrantes. Na verdade, estes momentos proporcionam oportunidades de desenvolvimento intelectual que se dá na expressão de seus integrantes para a sustentação de seus pontos de vista, tornando o debate mais rico na sua dialética, podendo assim ser estimulada a habilidade de mediação, assim como é feito para a habilidade de criatividade.

\subsection{3}

\section{Conflitos nas disciplinas do curso de Design}

Ao longo destes quatro anos dos cursos de graduação em Design, quase sempre desperdiçamos a oportunidade de trabalhar as competências necessárias para que designers tenham habilidades para mediar conflitos intragrupais, certos de ocorrerem na prática dos projetos colaborativos de Design em suas vidas profissionais.

O cenário da sala de aula onde se dá a formação de designers no curso de graduação possui esta possibilidade para se transformar numa habilidade que a prática profissional necessita. Mediar passa por entender interesses, compreender pontos de vistas distintos, buscar pontos de conexão para que se construa caminhos com maior somatório de saberes aplicados no formato final da convergência construída pelo grupo. Será que podemos obter soluções mais inovadoras em ambientes onde a mediação é praticada de forma eficiente?

Quando trabalhamos em grupo, as discussões revelam o pensamento de seus indivíduos onde teses e antíteses são necessárias para que cheguemos à síntese que determina o caminho que o grupo deseja evoluir em seu trabalho.

Desta forma, os conflitos também podem ser um interessante propulsor criativo, pois, de acordo com Linda A. Hill em seu livro Genius, The Art and Practice of Leading Innovation[25], são necessárias três habilidades para que grupos trabalhem ativamente na construção de ideias inovadoras:

- Criatividade Abrasiva, que é a habilidade de gerar ideias através do debate e discussão de pontos de vista distintos;

- Criatividade Resolutiva, que é a habilidade de integrar ideias opostas através de mediação de interesses;

- Agilidade Criativa, que é a habilidade de testar rapidamente através de experimentos, para que o grupo reflita e tire as suas conclusões.

O conflito, na avaliação de Linda A. Hill, é um motivador que extrai do indivíduo não o comportamento beligerante, mas sim a capacidade intelectual de argumentação, construindo assim uma dialética benéfica que eleva o grau de discussão intragrupal, contribuindo para que o grupo construa soluções mais 
criativas e inovadoras. Por isto, o papel do Design como mediador de conflitos necessita ser estudado, estruturado tecnicamente e proposto, diferentemente do papel de facilitador atribuído frequentemente aos designers em grupos de trabalho colaborativo. A facilitação pode ser uma ferramenta a ser utilizada na mediação, mas a mediação não é um facilitador do processo, e sim uma necessidade a ser praticada para encontrar o formato da convergência de pensamentos.

As situações vividas nas disciplinas de projeto são fortes referências na construção do conhecimento teórico e prático no curso de Design. Estes projetos trazem o mundo real para a sala de aula, permitindo que seja percebida a complexidade que caminha junto a prática projetual. Estas disciplinas estão repletas de processos decisórios onde a mediação se torna necessária para que o resultado do trabalho seja obtido com maior somatório possível do saber dos integrantes dos grupos aplicados no resultado final do trabalho. Desta forma, torna-se fundamental observar ainda mais o processo como a evolução do grupo se dá, do que o objeto apresentado como resultado final do projeto.

O Design propõe processos cada vez mais participativos, centrado no humano e colaborativo, onde os métodos de mediação de conflitos intragrupais possam ser melhor estudados e praticamos ao longo do curso de Design, utilizando algo que por ora evitamos, mas que podem ser insumos para a construção de uma experiência que na prática certamente iremos nos confrontar. Desta forma, torna-se necessário observar mais atentamente para os conflitos muito frequentes nos grupos de trabalho para que deste consigamos aplicar técnicas para media-los como um conteúdo a ser ensinado e por fim construir algum tipo de técnica própria do Design.

Ao longo do curso mostramos como o Design utiliza o Duplo Diamante como método para conduzir projetos de maneira grupal de trabalho, levando os alunos a entenderem os esforços intelectuais necessários em cada momento em que o projeto se encontra. As habilidades artísticas são estimuladas em diversas disciplinas ao longo do curso, que quando aplicadas no contexto da facilitação são poderosas armas para que designers consigam superar as dificuldades de entendimento de pensamentos durante o processo grupal. Porém, a mediação acaba sendo uma competência pouco explorada, pois para que a sua prática seja exercida, torna-se necessário que haja conflitos. Se consideramos os conflitos como indesejáveis para processos de criação colaborativa e participativa, podemos estar desperdiçando uma poderosa condição presente ao longo do aprendizado no curso de Design, que através da mediação poderá se tornar uma das habilidades em que o Design poderá obter destacar em sua prática profissional. 


\section{6}

\section{Conclusões e recomendações da dissertação}

Os quase dois anos nos quais me dediquei a realização deste trabalho, iluminaram a minha percepção do papel de designers quando estes optam por trabalharem com Design de Serviço. A minha formação acadêmica, que teve sua origem na graduação em Design de Produto, passando por Marketing e Gestão Empresarial, contribuíram para que o meu aprendizado e entendimento sobre o Design de Serviço fosse algo amistoso, pois a prática neste ramo requer múltiplos conhecimentos que adquiri em 30 anos de formação profissional, que me habilitaram a trabalhar com Design de Serviço nos últimos 12 anos.

Entretanto, ao buscar as origens do Design de Serviço, descritas no Capítulo 2, percebi o quanto é importante ter não apenas visão holística, mas também muita maturidade, para entender problemas multifatoriais e não lineares em sua solução, e que para solucioná-los precisamos consultar atores com pontos de vista diversos. Para que possamos nos candidatar a sermos agentes de um processo de transformação que o Design de Serviço promete, torna-se necessária que se tenha habilidades ligadas a mediação de conflitos intragrupais, certos de ocorrerem em atividade participativas e colaborativas, tão necessárias para se ter visão holística fruto da interação intragrupal.

Vivenciar e saber observar, para que se consiga extrair uma interpretação mais próxima da realidade que o problema apresenta, possibilita aos profissionais que trabalham com Design de Serviço consigam planejar e agir estrategicamente na direção de inspirar pessoas para que colaborem com soluções mais harmônicas e também verdadeiras. A implementação de uma solução depende muito da motivação dos envolvidos, para que a participação destes seja incremental, contribuindo para que os resultados obtidos pelo processo criativo seja menos alegórico e não perecível numa sociedade que consome novidade por minuto.

Observar a formação de designers à luz das ferramentas CANVAS trouxe a oportunidade de perceber a dificuldade de designers e não designers em lidar com o tratamento dos campos que tratam de finanças, matemática e marketing existem, fato apurado nas pesquisas feitas com profissionais que trabalham com Design de Serviço, apresentado no Capítulo 4. Entretanto, torna-se fundamental saber dialogar com estes saberes, entendendo a lógica que 
está contida em suas práticas, sem que se saiba necessariamente as profundezas dos detalhes específicos que cada área possui. A complementaridade dos times é algo que se deve ter atenção, pois no trabalho participativo e colaborativo se busca o somatório de saberes em prol da criatividade, mesmo que esta traga conflitos intragrupais, onde os insights gerados no trabalho grupal necessitam ser debatidos, questionados e criticados, para que se transformem em ideias poderosas e transformadoras.

Se o Design é multidisciplinar, transdisciplinar ou interdisciplinar, estas afirmações sugerem que designers necessitam ter competência de adaptação constante para ajustar o uso das ferramentas CANVAS quando observa que a interação do grupo não apresenta a energia necessária para a resolução dos problemas projetuais. é necessário entender a arquitetura social de um grupo de trabalho antes que os ajustes sejam realizados, pois podemos estar simplificando o processo e não facilitando a sua condução. Por outro lado, para se trabalhar coletivamente de forma participativa estes ajustes necessitam ser pactuados dentro da estrutura grupal e não arbitrados por alguém.

A pesquisa buscou encontrar novos saberes que se tornam necessários aos profissionais de Design que buscam atuações colaborativas onde a participação dos integrantes de um grupo formado para se projetar algo é fundamental. O Design de Serviço e os CANVAS iluminaram este percurso. A pesquisa proporcionou a oportunidade de coletar a experiência de profissionais que atuam na área de Design de Serviço, fornecendo dados quantitativos e qualitativos. Na parte quantitativa, diversos cruzamentos de respostam ainda podem ser realizados. Uma coleta adicional destes dados já se iniciou com profissionais da Suíça. Os áudios das entrevistas da pesquisa qualitativa ficarão disponíveis por 5 anos para consultas, que poderão gerar novos debates sobre as conclusões deste estudo realizado. Acredito estar construindo uma base para que outros profissionais com interesse pelo tema possam contribuir para que cheguemos a novas conclusões.

Além disto, a pesquisa também trouxe um levantamento de CANVAS que foram selecionados por área de aplicação, sendo um facilitador para aqueles que buscam uma revisão qualitativa sobre os CANVAS que proliferam a cada busca realizada na internet. Desta forma, a pesquisa apontou para a tendência de que novos CANVAS surgem a cada dia, sendo importante que se saiba o modo de se manejar estar ferramentar em conjunto com a opinião e pontos de vistas do grupo de trabalho que se forma entorno dela.

A pesquisa proporcionou identificar as dificuldades que os profissionais têm no uso das ferramentas CANVAS, revelando que a maior delas está associada a como lidar com o comportamento do grupo formado para utilizá- 
las, já que diversos saberes são necessários para o entendimento dos propósitos que a dinâmica sugere. O designer se utiliza de suas habilidades no campo de representação gráfica para facilitar as dinâmicas grupais, mostrando o quanto é importante que designers tenham habilidade em sintetizar graficamente conceitos, ideias e falas dos integrantes do grupo de trabalho. Entretanto, além desta habilidade, notou-se um potencial a ser explorado na mediação de conflitos intragrupais, uma unanimidade na fala dos entrevistados e ainda sem uma técnica para conduzir as antíteses para uma convergência de pensamento que resulte em ideias mais completas e com a contribuição do somatório dos saberes contidos no grupo. Os conceitos de Criatividade Abrasiva, Criatividade Resolutiva e Agilidade Criativa, citados no Capítulo 5, podem ser melhor explorados no campo do Design, para dar suporte ao processo de divergência que o Duplo Diamante propõe. Sem que se tenha uma técnica, ou saber para promover a convergência, os conflitos podem comprometer o propósito de formação do grupo, pois durante a formação de designers os conflitos não são considerados como insumos para um aprendizado necessário em sua trajetória profissional.

A conclusão desta dissertação serve de base para uma trajetória a ser perseguida em trabalhos futuros. As respostas que obtive em minha pesquisa apontam para competências necessárias quando nos dedicamos a construir algo de forma colaborativa. Uma delas está associada à capacidade de conduzir processos onde a participação de pessoas com saberes distintos, quer como colaboradores, apoiadores, mentores e fornecedores, ocorra em sinergia. Podemos considerar que esta habilidade deva fazer parte da formação de um designer, pois ela possibilita que designers consigam formar grupos de trabalho operativos, com propósitos cristalinos, vínculos estabelecidos, papéis definidos e tarefas claras para os seus integrantes. Os estudos de Enrique PichonRivière [29] e de Sigmung Freud [30] poderão iluminar os caminhos a serem percorridos por designers, trazendo os conhecimentos da psicologia para buscar métodos de como tratar esta complexidade presente nos ambientes de projetos participativos e colaborativos.

Uma questão muito presente nas entrevistas e nos estudos da pesquisa realizada foi a participação do Design para resolver "Problemas Complexos", revelando a influência do texto de Richard Buchanan, Wicked Problems in Design Thinking[17], no pensamento e forma de atuação do Design na sociedade. Entretanto, complexidade é algo que necessita ser medido para que tenhamos a real dimensão do que estamos enfrentando. A complexidade passa por entender a interdependência entre propósitos, processos, estratégias, estrutura e pessoas. No campo do Design, percebo a necessidade de um modelo 
onde se possa estabelecer o grau de complexidade de um projeto, tarefa ou situação, para que o grupo entenda a dimensão do desafio e busque, de forma operativa, alcançar o compromisso pactuado.

Por último, uma questão muito presente na investigação deste trabalho está associada à necessidade de mediação de interesses conflitantes, algo sempre presente quando o trabalho é realizado por grupos multidisciplinares. Nesta última questão, poucas referências encontrei no campo do Design, quer por intermédio de algum autor, técnica, CANVAS ou processo. Desta forma, a mediação aplicada ao processo criativo torna-se um relevante tema de pesquisa para o campo do Design, por se tratar de uma habilidade que já vem sendo demanda em processos criativos grupais. Nas entrevistas realizadas em minhas investigações, todos informaram haver conflitos nos trabalhos em grupos, e as soluções para mediá-los estavam ligadas às características pessoais, comportamentais ou históricas dos indivíduos. Isso mostra mais uma habilidade a ser estruturada como saber, tão necessária para o Design, que se propõe a trabalhar em grupo, de forma colaborativa, para solucionar problemas complexos para uma sociedade cada vez mais diversificada.

Estes aspectos descritos acima poderão ser os norteadores para trabalhos futuros na busca de contribuir para a formação de futuros designers. 


\section{Referências bibliográficas}

[1] MOGGRIDGE, B.. Designing Interactions. MIT Press, Cambridge, MA, 1st edition, 2007.

[2] STICKDORN, M.; HORMESS, M.; LAWRENCE, A.; SCHNEIDER, J.. This Is Service Design Doing: Applying Service Design Thinking in the Real World. O'Reilly Media, Sebastopol, CA, 1st edition, 2018.

[3] OSTERWALDER, A.. The Business Model Ontology: a proposition in a design science approach. PhD thesis, Université de Lausanne, Ecole des Hautes Etudes Commerciales, 2004.

[4] SHOSTACK, G. L.. Designing services that deliver. Harvard Business Review, 62 (1):133-139, 1984.

[5] SERVICE DESIGN NETWORK. About Service Design and the SDN, 2020. Acesso em: Maio de 2020.

[6] KAPLAN, R. S.; NORTON, D. P.. The balanced scorecard - measures that drive performance. Harvard Business Review, 70 (1):71-79, 1992.

[7] KAPLAN, R. S.; NORTON, D. P.. Putting the balanced scorecard to work. Harvard Business Review, 71 (5):134-147, 1993.

[8] KAPLAN, R. S.; NORTON, D. P.. The Balanced Scorecard: Translating Strategy into Action. Harvard Business School Press, Boston, MA, illustrated, reprint edition, 1996.

[9] OSTERWALDER, A.; PIGNEUR, Y. AND CLARK, T.. Business Model Generation: A Handbook for Visionaries, Game Changers, and Challengers. John Wiley \& Sons, Hoboken, NJ, 1st edition, 2010.

[10] GOMES, A. S.. O canvas do modelo de negócio. HSM MANAGEMENT, Revista, 99 (4):26-33, Julho-Agosto 2013.

[13] FINOCCHIO, J.. Project Model Canvas. ALTA BOOKS, 2013.

[14] PIJL, P.; LOKITZ, J.; SOLOMON, L.; PLUIJM, E.; LIESHOUT, M.. Design a Better Business: New Tools, Skills, and Mindset for Strategy and Innovation. John Wiley \& Sons, Hoboken, N.J., 1st edition, 2016. 
[15] CLARK, T.; OSTERWALDER, A. AND PIGNEUR, Y.. Business Model You: A One-Page Method For Reinventing Your Career. John Wiley \& Sons, Hoboken, NJ, 2012.

[16] ELIAS, M.. Conheça o "T\&D Canvas", uma ferramenta para apoiar as ações de T\&D. Portal Administradores.com, 2016. Acesso em: Maio de 2020.

[17] BUCHANAN, R.. Wicked problems in design thinking. Design Issues, 8 (2):5-21, Spring 1992.

[19] COUTO, R.M.S.; OLIVEIRA, A.J.; FARBIARZ, J.L.; NOVAES, L.. Formas do Design: por uma metodologia interdisciplinar. Rio Book's, Rio de Janeiro, RJ, 2nd revisada e ampliada edition, 2014.

[21] MICHAELIS. Mediação. Acesso em: Outubro de 2019.

[21] GOMES, R.; BARROS PONTES E SILVA, T.. A importância do designer como mediador de relações humanas. Blucher Design Proceedings, 2(2):1711 - 1714, 2015.

[23] MORIN, E.. Introdução ao pensamento complexo. Sulina, Porto Alegre, 5 edition, 2015.

[24] RITTEL, HORST W. J. AND WEBBER, MELVIN M.. Dilemmas in a general theory of planning. Policy Sciences, 4(2):155-169, June 1973.

[25] HILL, L.A. AND BRANDEAU, G. AND TRUELOVE, E. AND LINEBACK, K.. Collective Genius: The Art and Practice of Leading Innovation. Harvard Business Review Press, Boston, MA, 2014.

[26] OLIVEIRA, M.. Uma visita a georg simmel: o "conflito" como uma categoria crítica de análise conceitual fundamental para os estudos antropológicos de violências no brasil. Revista de Ciências Humanas, 43, 052009.

[27] EDUCAÇÃO, M. D. E. C. N. D.. Diretrizes curriculares nacionais dos cursos de graduação em música, dança, teatro e design. Acesso em: Setembro de 2020.

[28] DESIGN COUNCIL UK. Design methods for developing services: an introduction to service design and a selection of service design tools, 2015. Acesso em: Maio de 2020. 
[29] PICHÓN-RIVIÉRE, ENRIQUE. Teoria do Vínculo. Editora Martins Fontes Editora Ltda., São Paulo-SP, 1980.

[30] FREUD, SIGMUND.. Psicologia de grupo e a análise do eu. Companhia das Letras, São Paulo, SP, 201q. 


\section{A}

\section{Published paper}

The following paper was published ... 